\title{
INDICADORES DE QUALIDADE ESTRUTURAL E TRAFEGABILIDADE DE LATOSSOLOS E ARGISSOLOS VERMELHOS
}

\author{
SILVIA DEL CARMEN IMHOFF
}

Tese apresentada à Escola Superior de Agricultura "Luiz de Queiroz", Universidade de São Paulo, para obtenção do título de Doutor em Agronomia, Área de Concentração: Solos e Nutrição de Plantas.

\author{
PIRACICABA \\ Estado de São Paulo - Brasil
}

Maio - 2002 


\title{
INDICADORES DE QUALIDADE ESTRUTURAL E TRAFEGABILIDADE DE LATOSSOLOS E ARGISSOLOS VERMELHOS
}

\section{SILVIA DEL CARMEN IMHOFF}

Engenheiro Agrônomo

\section{Orientador: Prof. Dr. ALVARO PIRES DA SILVA}

\author{
Tese apresentada à Escola Superior de \\ Agricultura "Luiz de Queiroz", Universidade \\ de São Paulo, para obtenção do título de \\ Doutor em Agronomia, Área de Concentração: \\ Solos e Nutrição de Plantas
}

\author{
PIRACICABA \\ Estado de São Paulo - Brasil
}

Maio - 2002 
Dados Internacionais de Catalogação na Publicação (CIP) DIVISÃO DE BIBLIOTECA E DOCUMENTAÇÃO - ESALQ/USP

Imhoff, Silvia Del Carmen Indic adores de qualidade estrutural e trafegabilidade de la tosssolose arg issolos vermelhos/ Silvia Del Camen Imhoff. - - Pira cicaba, 2002.

$94 \mathrm{p}$.

Tese (doutora do) - Escola Superior de Agric ultura Luiz de Queiroz, 2002. Bibliografia.

1. Compactação dos solos 2. Compressibilida de dos solos 3. Estrutura do solo 4. Física do solo 5. Latossolo 6. Podzólic o 7. Resistência dos solos I. Título

CDD 631.44 


\section{AGRADECIMENTOS}

Ao Professor Alvaro Pires da Silva pela orientação, ensinamentos e incentivo permanentes que tanto contribuíram para minha formação profissional.

Á amiga e colega Neyde Giarola pelos ensinamentos e apoio durante o convívio.

Aos colegas de pós- graduação Claudia Rodrigues de Lima, Herdjania Veras de Lima e Tairone Paiva Leão pela amizade e ajuda na realização deste trabalho.

Aos técnicos de Laboratório de Física de Solos, Flávia Morales, Jair Ferrer da Silva, Luciano Dias Ferraz e Wladmir Rosignolo, pela amizade e ajuda durante o desenvolvimento do trabalho.

À bibliotecária Eliana Sabino pelas correções que ajudaram a melhorar esta Tese.

À Facultad de Ciencias Agrarias de Esperanza, Universidad Nacional del Litoral, pela liberação para a realização do curso de pós-graduação.

À CAPES pela concessão da bolsa de estudos.

À Coordenação do Curso de Solos e Nutrição de Plantas da ESALQ/USP pela oportunidade de realizar o curso.

À amiga Celia R. Montes pela correção deste trabalho e, especialmente, pela amizade que tanto me ajudou em momentos difíceis. 


\section{SUMÁRIO}

Página

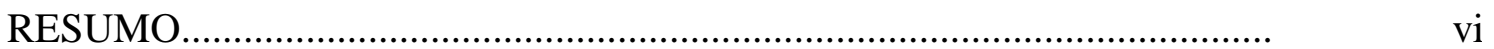

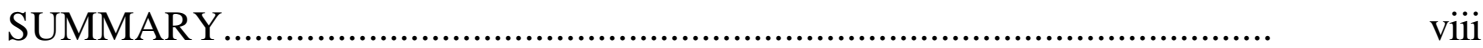

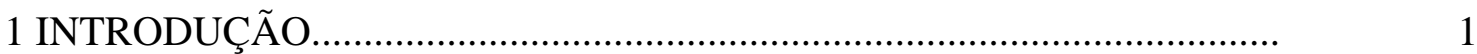

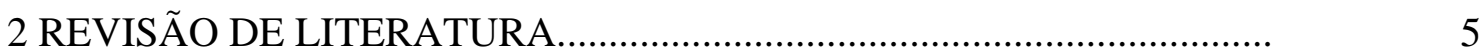

3 FATORES RELACIONADOS À RESISTÊNCIA TÊNSIL E FRIABILIDADE DE LATOSSOLOS VERMELHOS ................................. 23

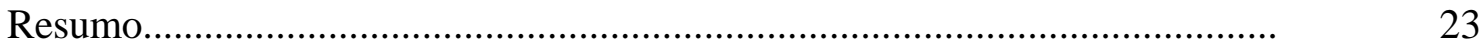

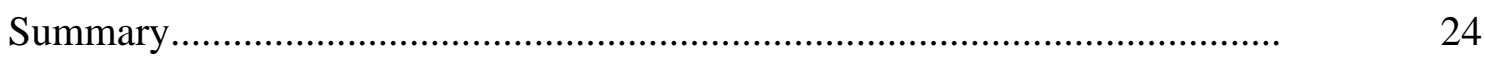

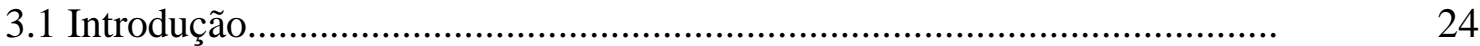

3.2 Material e Métodos..............................................................................

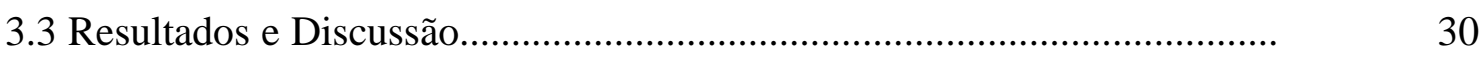

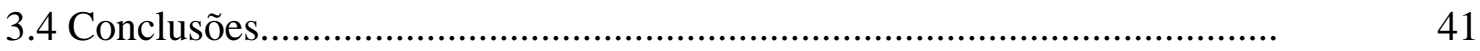

4 INFLUÊNCIA DE ATRIBUTOS FÍSICOS NA SUSCEPTIBILIDADE À COMPACTAÇÃO, CAPACIDADE DE SUPORTE E COMPRESSIBILIDADE DE LATOSSOLOS VERMELHOS...................... 43

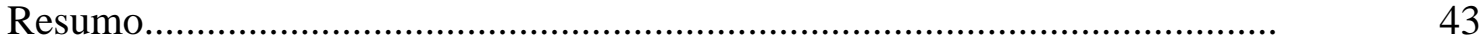

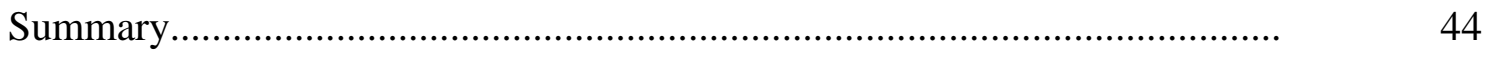

4.1 Introdução.............................................................................

4.2 Material e Métodos............................................................................. 47

4.3 Resultados e Discussão.................................................................. 51

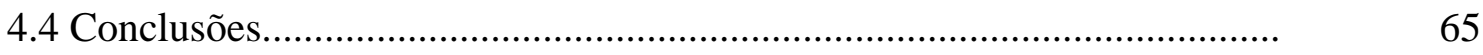


5 QUANTIFICAÇÃO DE PRESSÕES CRÍTICAS PARA O

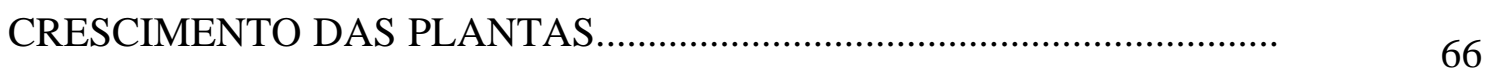

Resumo

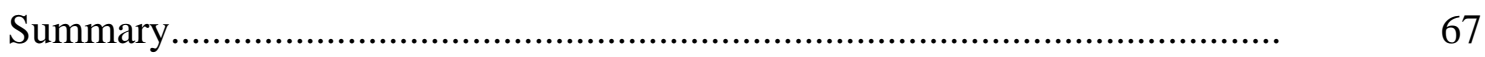

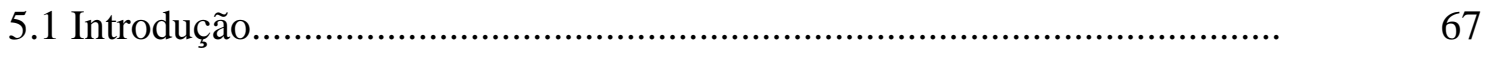

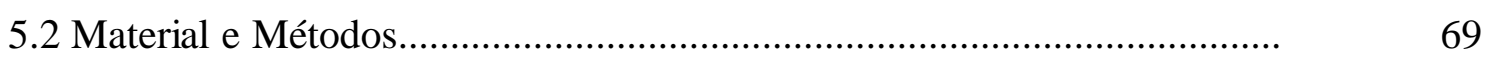

5.3 Resultados e Discussão...........................................................................

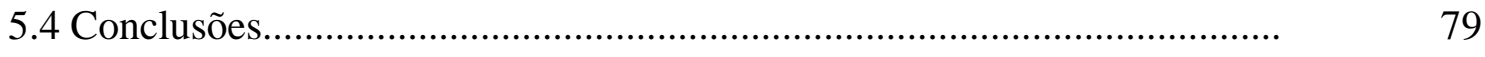

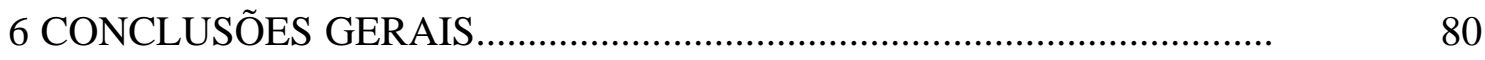

REFERÊNCIAS BIBLIOGRÁFICAS......................................................... 


\title{
INDICADORES DE QUALIDADE ESTRUTURAL E TRAFEGABILIDADE DE LATOSSOLOS E ARGISSOLOS VERMELHOS
}

\author{
Autora: SILVIA DEL CARMEN IMHOFF \\ Orientador: Prof. Dr. ALVARO PIRES DA SILVA
}

\section{RESUMO}

O solo, além de ser um dos recursos básicos dos ecossistemas naturais e agropecuários, é considerado um recurso finito, frágil e não renovável, razão pela qual a manutenção de sua qualidade tem adquirido grande relevância nas últimas décadas. Diversos indicadores de qualidade física do solo foram avaliados em solos de clima temperado no intuito de desenvolver normas de preparo e trafegabilidade que permitam definir as práticas de manejo mais adequadas e o momento mais oportuno para efetua-las visando conservar o recurso solo. Entretanto, é escassa a informação para solos desenvolvidos sob a influência do clima tropical. Nesse contexto, o objetivo geral desta pesquisa foi avaliar, quantitativamente, diversos indicadores de qualidade física do solo direta e indiretamente relacionados à produtividade das culturas, e desenvolver funções de pedotransferência que permitam estimar esses indicadores a partir de atributos físicos facilmente mensuráveis, para Latossolos e Argissolos Vermelhos. Os objetivos específicos foram: $i$ ) avaliar os indicadores da condição estrutural do solo "resistência tênsil dos agregados" e "friabilidade" e, determinar a influência de atributos físicos intrínsecos nesses indicadores; ii) quantificar os indicadores de trafegabilidade "susceptibilidade à compactação", "pressão de preconsolidação" e "compressibilidade" e, determinar a influência da umidade, matéria orgânica, textura e estrutura nesses 
indicadores; iii) avaliar o indicador de qualidade estrutural "intervalo hídrico ótimo" e o indicador de trafegabilidade "pressão de preconsolidação", relacioná-los e determinar valores de pressões críticas que podem ser aplicados ao solo sem induzir condições restritivas ao crescimento das plantas e compactação adicional do solo; e $i v$ ) desenvolver funções de pedotransferência que permitam estimar os indicadores avaliados a partir de atributos do solo facilmente mensuráveis. Os resultados referentes ao objetivo $i$ ) indicaram que a resistência tênsil dos agregados foi positivamente relacionada com os teores de silte+argila e matéria orgânica, e que os óxidos de Fe pouco cristalinos foram os constituintes da fração silte+argila que mais influenciaram a resistência dos agregados. Os solos estudados foram muito friáveis, estando a friabilidade relacionada positivamente com o teor de óxidos de Fe cristalinos. Os resultados referentes ao objetivo $i$ ) mostraram que o índice de compressão foi significativamente relacionado com a textura (teor de argila) e estrutura (densidade do solo). A pressão de preconsolidação foi significativamente relacionada com a umidade, densidade do solo e o teor de argila. A compressibilidade do solo foi dependente da densidade do solo. Os resultados referentes ao objetivo iii) indicaram que o intervalo hídrico ótimo e a pressão de preconsolidação foram relacionados com a densidade do solo e a umidade. A partir do intervalo hídrico ótimo foi obtida a densidade do solo crítica para o crescimento das plantas, que foi utilizada para a quantificação de pressões críticas. A pressão crítica para o desenvolvimento das plantas foi negativa e linearmente relacionada com o incremento da umidade. No que se refere ao objetivo $i v$ ), foram geradas funções de pedotransferência que permitem estimar os indicadores avaliados a partir de atributos do solo facilmente mensuráveis. 


\title{
INDICATORS OF STRUCTURAL QUALITY AND TRAFFICABILITY OF HAPLUDOX AND HAPLUDALF
}

\author{
Author: SILVIA DEL CARMEN IMHOFF \\ Adviser: Prof. Dr. ALVARO PIRES DA SILVA
}

\section{SUMMARY}

The soil, besides being one of the basic resources of the natural and agricultural ecosystems, has been considered a finite, fragile and no renewable resource. For this reason the maintenance of its quality has been acquiring great relevance in the last decades. Several soil physical quality indicators have been used with the intention of developing guides of workability and trafficability that allow to define the more appropriate management practices and the most opportune moment for applying them in view to conserve the soil quality. However, it is scarce the information for soils developed under the influence of tropical climates. In this context, the general objective of this research was to evaluate, quantitatively, several indicators of soil physical quality that are directly and indirectly related to the productivity of the cultures, and to develop pedotransfer functions to make possible to estimate those indicators using easily measurable soil attributes for Hapludox and Hapludalf. The specific objectives were: $i$ ) to evaluate the workability indicators "tensile strength of the aggregates" and "friability" and, to determine the influence of the soil intrinsic properties on those indicators; $i i$ ) to quantify the trafficability indicators"susceptibility to compaction", "preconsolidation pressure" and "compressibility", and to determine the influence of soil water content, 
organic matter, texture, and structure on those indicators; iii) to evaluate the structural quality indicator "least limiting water range" and the trafficability indicator "preconsolidation pressure", to relate them, and to determine values of critical pressures that can be applied to the soil without inducing restrictive conditions to plant growth and additional soil compaction; and $i v$ ) to develop pedotransfer functions to estimate the measured indicators using easily measurable soil attributes. The results related the objective $i$ ) indicated that soil tensile strength was positively related to clay+silt content and organic matter, and that poorly crystalline iron oxides were the constituent of clay+silt fractions that most contributed to soil tensile strength. Results also indicated that the soils were highly friable, with the crystalline iron forms being positively related to soil friability. The results related to the objective ii) showed that the compression index was significantly related to soil texture and soil bulk density. The preconsolidation pressure was significantly related to soil water content, soil texture (clay content), and bulk density. The soil compressibility was related to bulk density. The results related to the objective $\mathrm{iii}$ ) showed that least limiting water range and preconsolidation pressure were related to soil bulk density and soil water content. The least limiting water range was used to obtain the soil critic bulk density for the plants growth, which in turn was used to quantify the soil critical pressures. The soil critical pressure for plant development was negative and linearly related to the increase of water content. Pedotransfer functions that make possible to estimate the evaluated indicators from easily measurable soil attributes were generated in answer to the objective $i v$ ). 


\section{INTRODUÇÃ̃o}

O solo é um dos recursos básicos dos ecossistemas naturais e agropecuários e, por ser um recurso finito, frágil e não renovável, a manutenção de sua qualidade tem adquirido importância fundamental nos últimos anos.

A qualidade do solo foi definida como a capacidade de determinada classe de solo para sustentar a produtividade vegetal e animal, manter ou aumentar a qualidade do ar e da água, e ser suporte para a vida saudável do homem, dentro dos limites de ecossistemas naturais ou manejados. Em geral, há um consenso acerca da necessidade de desenvolver e quantificar indicadores que permitam avaliar a qualidade dos solos, de forma a gerar normas que permitam proteger a capacidade natural dos ecossistemas para funcionar adequadamente. Visto que o solo é uma unidade tridimensional complexa, com atributos biológicos, químicos e físicos, os indicadores de qualidade do solo devem integrar, pelo menos, alguns desses atributos. Entre todos os indicadores, os relacionados à qualidade física dos solos possuem especial importância visto que esta, quando deteriorada, é difícil de recuperar.

Diversos atributos são utilizados como indicadores da qualidade física dos solos. Entretanto, há consenso que os indicadores deveriam incluir os atributos que influenciam diretamente a produção das culturas, ao determinar a magnitude com a qual a matriz do solo resiste a deformação e a capacidade do solo para fornecer adequada aeração e quantidade de água para as plantas, e aqueles que influenciam indiretamente a produtividade ao determinar as condições de preparo e trafegabilidade dos solos. Um número mínimo de indicadores deveria ser escolhido, os quais, além de terem impacto sobre a produtividade das culturas, deveriam ser facilmente mensuráveis e sensíveis às variações de clima e manejo. Para ampliar a utilidade desses indicadores têm sido 
sugerido o desenvolvimento de funções de pedotransferência; ou seja, funções matemáticas que permitam estimar esses indicadores a partir de atributos do solo facilmente mensuráveis.

A resistência tênsil dos agregados é um dos atributos físicos mais amplamente utilizado como indicador da condição estrutural do solo após as atividades de preparo. Problemas no estabelecimento das culturas foram associados com condições físicas inadequadas da cama de semeadura decorrente de valores elevados de resistência dos agregados. A heterogeneidade da resistência tênsil dos agregados ao fraturamento foi definida como friabilidade do solo. Esse parâmetro também é utilizado como indicador da qualidade do solo, uma vez que a condição de solo friável é desejável para o estabelecimento de uma cama de semeadura de qualidade adequada para a germinação e crescimento das plântulas dos cultivos agrícolas. Embora os dois indicadores tenham sido amplamente avaliados em solos de clima temperado e submetidos a diferentes manejos, há carência de informação acerca dos mesmos para solos desenvolvidos sob a influência de clima tropical.

Parâmetros obtidos a partir da curva de compressão do solo, como o índice de compressão e a pressão de preconsolidação, são freqüentemente utilizados como indicadores da trafegabilidade do solo. O processo de compressão depende primariamente das propriedades físico-mecânicas dos solos, sendo a umidade, a textura e o teor de carbono orgânico as de maior influência. Na literatura internacional há abundante informação sobre esses indicadores, principalmente para solos de variada textura, bem como modelos que relacionam esses indicadores com os atributos intrínsecos dos solos. Entretanto, há necessidade de desenvolver pesquisas básicas e aplicadas que permitam uma melhor compreensão do processo de compressão dos solos de regiões tropicais e integrar essas informações em modelos que possibilitem estimar os efeitos da compactação em solos com ampla variação nos atributos físicos.

O intervalo hídrico ótimo (IHO), definido como a faixa de conteúdo de água do solo menos limitante ao crescimento das plantas, e a pressão de preconsolidação $\left(\sigma_{\mathrm{p}}\right)$, definida como a carga máxima que o solo suportou no passado, também têm sido freqüentemente utilizados para avaliar a condição física dos solos. O primeiro é utilizado 
como indicador da qualidade estrutural do solo para o crescimento das plantas. $\mathrm{O}$ segundo é utilizado para avaliar a trafegabilidade do solo, uma vez que a aplicação de cargas maiores que esse valor induzem a uma compactação adicional e, decorrente disso, à degradação da qualidade estrutural do solo. Pesquisas têm demonstrado, isoladamente, que a degradação física do solo altera os valores dos dois indicadores por estarem estes relacionados com propriedades como a densidade e umidade do solo. Dessa forma, a alteração de um deles $\left(\sigma_{\mathrm{p}}\right)$ pode implicar numa redução do outro (IHO), induzindo condições restritivas ao crescimento das plantas. Apesar da relevância do tema, há carência de estudos que relacionem o indicador de trafegabilidade, a $\sigma_{\mathrm{p}}$, e o indicador de qualidade estrutural do solo para o crescimento das plantas, o IHO.

A partir das informações da literatura levantourse a hipótese que indicadores de qualidade física da cama de semeadura e de capacidade de suporte para o tráfego, de Latossolos e Argissolos Vermelhos, podem ser estimados a partir de atributos do solo facilmente mensuráveis utilizando funções de pedotransferência. Nesse contexto, o objetivo geral desta pesquisa foi avaliar, quantitativamente, diversos indicadores de qualidade física dos solos direta e indiretamente relacionados à produtividade das culturas, e desenvolver funções de pedotransferência que permitam estimar esses indicadores a partir de atributos físicos facilmente mensuráveis, para Latossolos e Argissolos Vermelhos.

Os objetivos específicos foram:

i) avaliar os indicadores da condição estrutural do solo "resistência tênsil dos agregados" e "friabilidade" e, determinar a influência de atributos físicos intrínsecos nesses indicadores;

ii) quantificar os indicadores de trafegabilidade "susceptibilidade à compactação", "pressão de preconsolidação" e "compressibilidade" e, determinar a influência da umidade, matéria orgânica, textura e estrutura nesses indicadores;

iii) avaliar o indicador de qualidade estrutural "intervalo hídrico ótimo" e o indicador de trafegabilidade "pressão de preconsolidação", relacioná-los e determinar valores de pressões críticas que podem ser aplicados ao solo sem induzir condições restritivas ao crescimento das plantas e compactação adicional do solo; 
iv) desenvolver funções de pedotransferência que permitam estimar os indicadores avaliados a partir de atributos do solo facilmente mensuráveis. 


\section{REVISÃO DE LITERATURA}

O solo é um dos recursos básicos dos ecossistemas naturais e agropecuários. Lal (1995) descreveu o solo como um recurso finito, frágil e não renovável. O autor assinalou que somente 22 \% (3,26 bilhões de ha) da área total do globo são adequadas para o cultivo, e só $3 \%$ (450 milhões de ha) possuem uma capacidade de produção elevada.

Além do recurso solo ser limitado, alguns de seus componentes requerem períodos de tempo muito prolongados para serem renovados que excedem, várias vezes, o tempo de vida do ser humano, razão pela qual a qualidade do solo tem se tornado um tema de interesse geral (Singer \& Ewing, 2000).

O termo qualidade do solo foi definido de várias formas. Em geral, pode-se afirmar que inclui a fertilidade do solo, o potencial de produção, a sustentabilidade do recurso e a qualidade do ambiente. Karlen et al. (1992) definiram a qualidade do solo como a "capacidade do solo para servir como meio natural para crescimento das plantas, as quais sustentam a vida humana e animal”. Gregorich et al. (1994) a definiram como "uma medida composta de ambas as capacidades do solo: para funcionar e para se ajustar a um uso específico”. Já Karlen et al. (1997) propuseram a seguinte definição de qualidade do solo: "capacidade de determinada classe de solo para funcionar, dentro dos limites de ecossistemas naturais ou manejados, para sustentar a produtividade vegetal e animal, manter ou aumentar a qualidade do ar e da água, e ser suporte para a vida saudável do homem". Essa definição ressalta a importância da qualidade do solo para a manutenção da produtividade a longo prazo e da qualidade ambiental. Os autores destacaram que a qualidade do solo devia ser avaliada em diferentes escalas: i) em escala 
detalhada (laboratório, parcelas pequenas), com pesquisas que tentem encontrar indicadores úteis para avaliar a qualidade do solo; ii) em escala de campo, com pesquisas que demonstrem como a qualidade do solo é alterada pelo clima, manejo e tipo de solo; iii) em escala global, com pesquisas orientadas a encontrar práticas de manejo que permitam manter e melhorar a qualidade do solo.

O glossário da SSSA (2002) estabelece que a qua lidade do solo é um atributo intrínseco deste, o qual pode ser inferido a partir de suas características e propriedades ou observações indiretas. Dessa forma, um número mínimo de atributos do solo (indicadores) deve ser medido para quantificar a qualidade do solo. Esses indicadores podem ser variáveis de estado simples (por exemplo, a temperatura do solo) ou complexas, sendo determinadas, nesse último caso, a partir de várias propriedades do solo (por exemplo, o intervalo hídrico ótimo, o qual é calculado a partir da resistência do solo à penetração, aeração e umidade na capacidade de campo e no ponto de murchamento permanente) (Burger \& Kelting, 1999). Os indicadores complexos são rotineiramente denominados como funções de pedotransferência (Bouma, 1989). Independentemente da classe de indicador utilizada, na escolha dos mesmos devem ser considerados diferentes critérios. Segundo Stenberg (1999) e Schoenholtz et al. (2000), os indicadores de qualidade do solo deveriam: i) integrar atributos e processos físicos, químicos e biológicos do solo; ii) incorporar a variabilidade das propriedades; iii) ser sensíveis a variações a longo prazo induzidas pelo clima e manejo, mas deveriam ser resistentes a flutuações de curto prazo provocadas pelas alterações sazonais; iv) ser mensuráveis precisamente através de uma ampla variedade de classes e condições de solos; v) ser simples de medir e ter um baixo custo; vi) ser adaptáveis para diversos sistemas.

Singer \& Ewing (2000) assinalaram que os indicadores de qualidade física deveriam incluir os atributos físicos do solo que influenciam a produção das culturas ao determinar: i) a magnitude com a qual a matriz do solo resiste a deformação e; ii) a capacidade do solo para fornecer adequada aeração e quantidade de água para o crescimento e expansão do sistema radicular. A profundidade efetiva de enraizamento, a porosidade total e a distribuição do tamanho dos poros, a distribuição do tamanho das 
partículas, a densidade do solo, a resistência do solo à penetração das raízes, o intervalo hídrico ótimo, o índice de compressão, a resistência dos agregados, entre outros, são os atributos mais amplamente utilizados como indicadores de qualidade física (Topp et al., 1997; Schoenholtz et al., 2000; Singer \& Ewing, 2000).

A resistência tênsil dos agregados é considerada um importante indicador da qualidade do solo, especificamente da cama de semeadura (Dexter \& Kroesbergen, 1985). Problemas no estabelecimento das culturas foram associados a valores elevados de resistência dos agregados (Ley et al., 1993). A elevada resistência tênsil dos agregados dificulta a penetração das semeadoras no solo, restringe a emergência das plântulas e reduz o crescimento das raízes em camadas secas do solo. A resistência tênsil dos agregados pode ser determinada por meio de testes indiretos e diretos. Os testes diretos são assim denominados porque duas forças de mesma direção e sentido oposto são aplicadas, diretamente, em dois extremos de um agregado, o qual é separado em duas partes pela ação dessas forças (Figura 1).

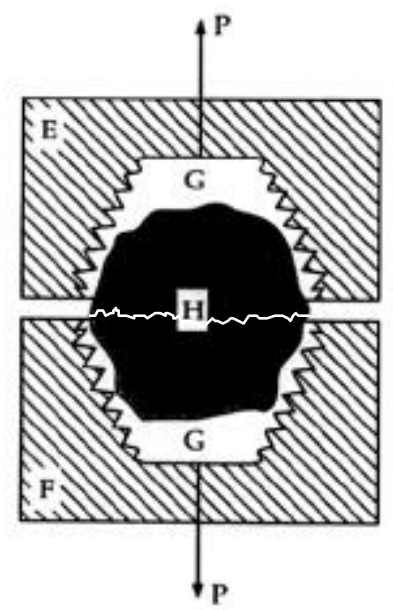

Figura 1 - Um agregado natural $(\mathrm{H})$ é fixado às metades $(\mathrm{E}$ e $\mathrm{F})$ de um recipiente por meio de "plaster de Paris" (mistura de calcário, areia e água) (G). O agregado é submetido à tração $(\mathrm{P})$, sendo separado em duas partes (Adaptada de Dexter \& Watts, 2000). 
Nos testes indiretos, o estresse não é aplicado diretamente sobre os agregados. Nesse caso, uma força compressiva é aplicada a uma placa que transmite a força através do diâmetro do agregado, o que produz incremento do estresse dentro do mesmo. $\mathrm{O}$ valor máximo de estresse tênsil ocorre no plano vertical através do centro da amostra (Figura 2). Quando o estresse tênsil supera a resistência tênsil dos agregados (força de mesma magnitude, mas sentido oposto), uma fissura aparece no centro do agregado, sendo dividido em unidades de menor tamanho e maior resistência (Dexter \& Watts, 2000).

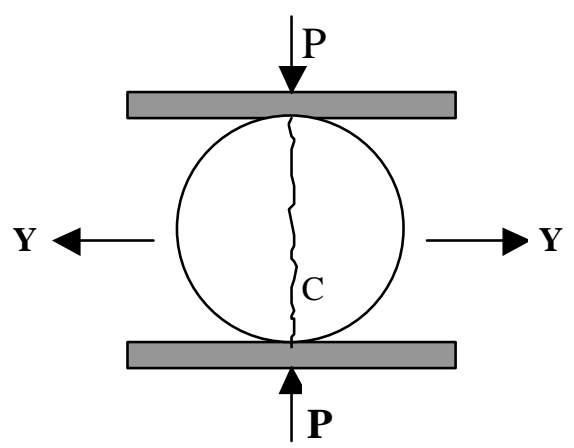

Figura 2- A fissura C, será formada entre os dois pontos de aplicação da força (P) devido ao estresse tênsil (Y), que atua no centro da amostra (Adaptada de Dexter \& Watts, 2000).

A resistência tênsil dos agregados $\left(\mathrm{Y}_{\max }\right)$ é calculada por meio da seguinte equação:

$$
Y_{\max }=0,576 * \frac{P}{D^{2}}
$$

Sendo: 0,576 a constante de proporcionalidade que reflete a relação entre o estresse compressivo aplicado e o estresse tênsil gerado no interior do agregado, $P$ a força aplicada, e $D$ o diâmetro efetivo do agregado.

A heterogeneidade da resistência tênsil dos agregados ao fraturamento, provocada pelas fissuras existentes dentro dos agregados, foi identificada como friabilidade do solo (Dexter \& Watts, 2000). Esse parâmetro (calculado como o desvio padrão dos valores da resistência tênsil dos agregados dividido pelo valor médio de resistência tênsil) também foi considerado uma propriedade física importante dos solos 
agrícolas, uma vez que a condição de solo friável é desejável para o estabelecimento de uma cama de semeadura de adequada qualidade para a germinação e crescimento das plântulas dos cultivos agrícolas (Watts \& Dexter, 1998). Utomo \& Dexter (1981) propuseram uma classificação dos solos com base nos valores de friabilidade (k). Os autores consideraram as categorias apresentadas na Tabela 1.

Tabela 1. Classificação dos solos em função da friabilidade (k) do solo.

\begin{tabular}{lc}
\hline \multicolumn{1}{c}{ Categorias } & Valor de $\mathbf{k}$ \\
\hline Solo não friável & $<0,05$ \\
Solo levemente friável & $0,05-0,10$ \\
Solo friável & $0,10-0,25$ \\
Solo muito friável & $0,25-0,40$ \\
Solo instável mecanicamente & $>0,40$ \\
\hline
\end{tabular}

Valores de k pequenos indicam tendência do solo a quebrar-se em fragmentos de tamanho arbitrário (muito grandes e muito pequenos) quando submetido às atividades de preparo, os quais são inadequados para a germinação e crescimento das plântulas. Um valor intermediário de $\mathrm{k}$ indica que agregados grandes possuem menor resistência tênsil que agregados pequenos e, portanto, podem ser quebrados em fragmentos pequenos mais facilmente. Solos que apresentam valores de k elevados apresentam tendência a desmanchar-se quando uma mínima força é aplicada, razão pela qual são impróprios para a sua utilização com culturas agrícolas mecanizadas (Utomo \& Dexter, 1981; Macks et al., 1996).

Pesquisas têm demonstrado que a resistência dos agregados e a friabilidade do solo são influenciados por diversos fatores, como umidade do solo (Utomo \& Dexter, 1981), teor de argila dispersa em água (Kay \& Dexter, 1992; Barzegar et al., 1994), composição e concentração da solução do solo (Rahimi et al., 2000), ciclos de umidecimento e secamento do solo (Dexter, 1988b; Kay \& Dexter, 1992), teor de argila e mineralogia (Kemper et al., 1987; Guérif, 1990, Ley et al., 1993), teor de matéria orgânica (Causarano, 1993; Perfect et al., 1995; Rahimi et al., 2000) e, presença de 
materiais ligantes e/ou cimentantes, como a sílica e aluminosilicatos pouco cristalinos (Kay \& Dexter, 1992; Kay \& Angers, 1999).

Em geral, o aumento no teor de argila induz incremento na resistência tênsil dos agregados e, portanto, redução da friabilidade (Bartoli et al., 1992a; Guérif, 1990; Kemper et al., 1987). Esse aumento parece ser função do incremento do número de cargas elétricas, o que favorece a formação de ligações entre partículas minerais e/ou partículas minerais e orgânicas.

Os óxidos de ferro e alumínio também foram assinalados como agentes importantes para a agregação do solo (Pinheiro-Dick \& Schwertmann, 1996; Barral et al., 1998; Igwe et al., 1999; Muggler et al., 1999). Óxidos de ferro e alumínio atuam como agentes ligantes entre partículas minerais, influenciando a estruturação do solo ao incrementar a resistência das regiões de fratura (Kay \& Angers, 1999). Em geral, esses óxidos parecem atuar em duas formas: i) os agregados podem ser formados em razão da atração entre partículas de óxidos positivamente carregadas e partículas da matriz do solo negativamente carregadas, principalmente daquelas que apresentam o tamanho que corresponde à fração argila; ii) os óxidos podem estar recobrindo a superfície das partículas minerais, unindo partículas de diferentes tamanhos (Kay \& Angers, 1999; Muggler et al., 1999). Em ambas as formas, os óxidos de ferro e alumínio podem alterar a carga superficial dos minerais, intensificando as ligações entre as partículas. Decorrente desse fenômeno, a resistência tênsil dos agregados aumenta. Por outro lado, alguns autores têm assinalado que os óxidos de ferro exercem pouca ou nenhuma influência na agregação do solo (Deshpande et al., 1968; Muggler et al., 1997), ou que o efeito desses agentes agregantes foi devido a sua interação com a matéria orgânica do solo e/ou teor de argila (Guérif, 1990; Bartoli et al., 1992a).

A matéria orgânica parece ter a capacidade de atuar como agente agregante ou desagregante, dependendo de sua composição química e da presença de outros materiais cimentantes (Goldberg et al., 1990). A influência da matéria orgânica parece depender, também, da natureza das áreas de fratura, que por sua vez, depende da textura do solo, da qualidade da matéria orgânica e da distribuição espacial da mesma dentro dos agregados (Kay \& Angers, 1999). A matéria orgânica pode ser incorporada dentro de 
poros muito pequenos, entre as unidades do solo classificadas como "domínios argilosos" e/ou "clusters" (agrupamentos maiores), contribuindo na estabilização de microagregados e, como conseqüência disso, incrementando a resistência dos agregados de tamanho maior (Dexter, 1988a). Por outro lado, Goldberg et al. (1990) e Kemper et al. (1987) assinalaram que se o tamanho dos ânions orgânicos é semelhante ao tamanho do eixo das partículas de argila, a sua adsorção específica pode compensar as cargas elétricas positivas, conferindo excesso de cargas elétricas negativas às partículas. Esse excesso de cargas negativas pode induzir a dispersão das partículas de argila, diminuindo a resistência tênsil dos agregados.

A influência dos fatores argila, óxidos de ferro e alumínio e matéria orgânica na resistência tênsil e friabilidade depende da composição do solo, condições climáticas e práticas de manejo (Macks et al., 1996; Watts \& Dexter, 1997). As atividades de preparo do solo podem induzir perda excessiva da resistência tênsil dos agregados ou seu aumento excessivo. A diminuição da resistência parece ser causada pela diminuição e/ou destruição das ligações químicas entre as partículas, tanto de natureza orgânica quanto inorgânica, tornando o solo mecanicamente instável. Por outro lado, o aumento excessivo da resistência tênsil foi associado ao incremento da quantidade de argila dispersa em água em solos fisicamente degradados, a qual se deposita nas fissuras existentes entre os agregados e atua como agente agregante (Dexter \& Watts, 2000). Ambos os efeitos exercem um impacto negativo sobre a qualidade física do solo.

Em regiões tropicais variações na topografia podem ser indicativas de mudanças na profundidade do sólum e grau de intemperismo químico e, em alguns casos, da presença de diferentes tipos de solos (Anjos et al., 1998). Solos de regiões tropicais podem apresentar a fração argila constituída por diferentes minerais, principalmente caulinita e/ou gibbsita, e óxidos de ferro e/ou alumínio (Muggler et al., 1999), os quais apresentam diferentes capacidades de agregação das partículas (Pinheiro-Dick \& Schwertmann, 1996; Muggler et al., 1999). Apesar da relevância do tema, há carência de informação sobre a influência da textura, mineralogia e teor de matéria orgânica na resistência dos agregados e friabilidade de solos no Brasil. 
Outros indicadores da qualidade física do solo, especificamente da trafegabilidade do solo, são aqueles obtidos a partir da curva de compressão do solo. Na primeira metade do século 19 foi observado que o tráfego dos animais durante as operações de preparo do solo induzia a compactação. Já, na segunda metade do século 19 e na primeira do século 20, a utilização de máquinas a vapor no cultivo das terras foi acompanhado de compactação excessiva. Nos últimos 30 anos, com a introdução de máquinas de elevada potência e peso na agricultura, o problema da compressão dos solos adquiriu importância mundial (Soane \& Ouwerkerk, 1994).

O termo compressão se refere ao processo que descreve o decréscimo no volume e deformação do solo por causas antropogênicas, ou seja, quando uma força externa é aplicada (Gupta \& Allmaras, 1987; Koolen, 1994). A compressão de solos saturados é chamada consolidação, enquanto que a compressão de solos não saturados é conhecida como compactação (Gupta \& Allmaras, 1987; Horn \& Lebert, 1994). Durante o processo de consolidação, a água é excluída dos poros da matriz do solo (Bradfort \& Gupta, 1986). O processo de compactação, entretanto, é caracterizado pela exclusão de ar (Hakansson \& Voorhees, 1998).

O termo compressibilidade indica a resistência do solo ao decréscimo de volume quando submetido a uma carga mecânica (Horn \& Lebert, 1994), sendo definido como a facilidade com que o solo diminui o volume quando uma determinada pressão (estresse) é aplicada (Bradfort \& Gupta, 1986; Gupta \& Allmaras, 1987). A compressibilidade é a expressão quantitativa da resposta do solo à compactação, dentro de limites preestabelecidos para a aplicação de certo estresse (Soane, 1990). A condição do solo resultante do processo de compactação é conhecida como estado ou grau de compactação (Hakansson et al. 1988; Hakansson \& Voorhees, 1998).

A resposta do solo à compactação é um fenômeno de elevada complexidade. A compressibilidade depende primariamente das propriedades físico-mecânicas do solo (Etana et al., 1997) e, em menor grau, do nível e modo de aplicação da energia utilizada para exercer a compactação (Faure, 1981). As relações entre os fatores de estresse e os atributos do solo são mostradas na Figura 3. 


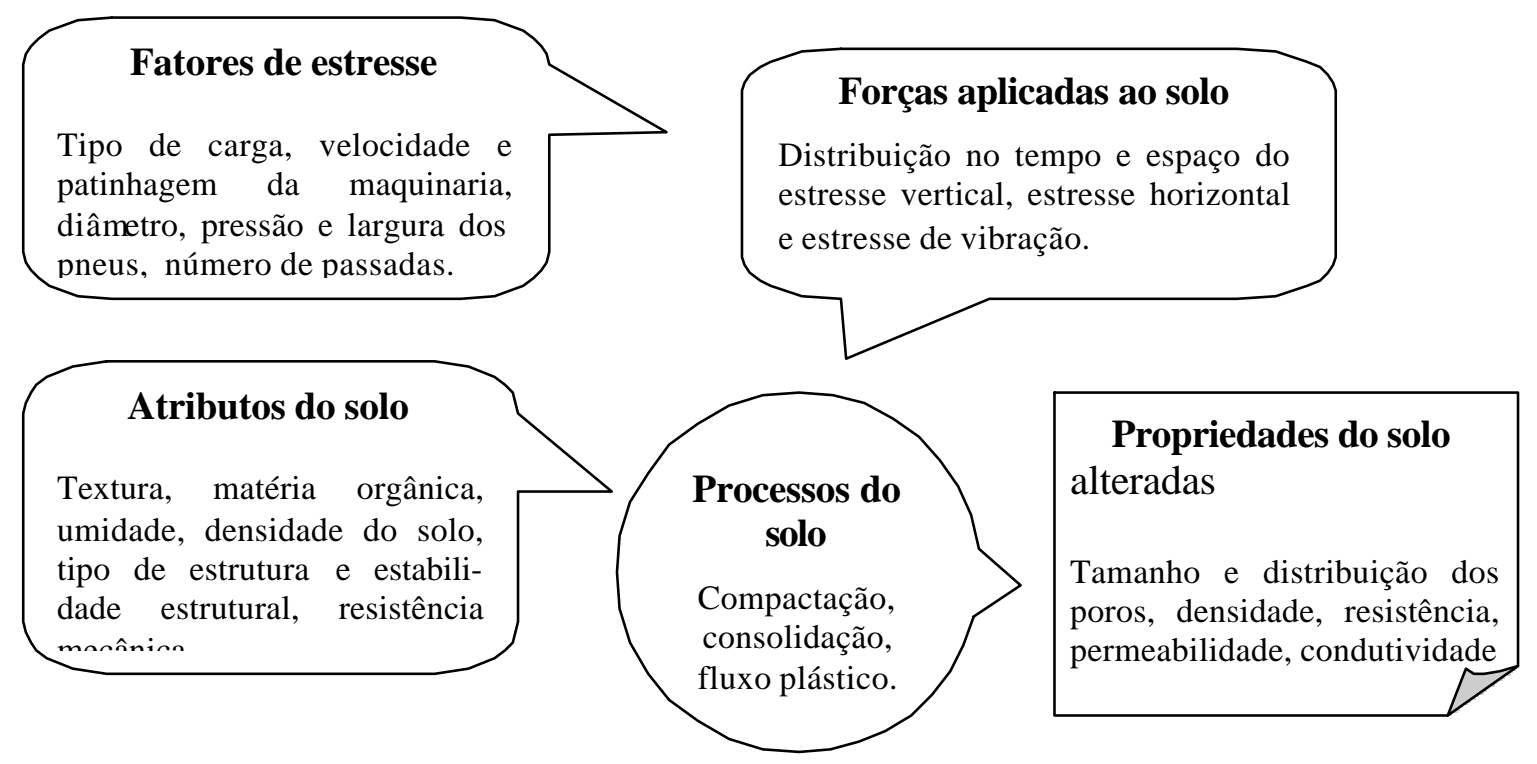

Figura 3 - Relações entre fatores de estresse, atributos iniciais e propriedades finais do solo durante a passagem da maquinaria (adaptada de Soane \& Van Ouwrkerk, 1994).

A textura é uma das propriedades do solo que mais influencia a sua compressibilidade (Hakansson et al., 1988; Horn, 1988; Larson et al., 1980; McBride, 1989). A distribuição do tamanho das partículas determina a forma de rearranjamento delas quando o estresse é aplicado e, decorrente disso, o grau de compactação (Soane, 1986; Horn \& Lebert, 1994). Várias pesquisas indicaram que o teor e o tipo de argila afetam o funcionamento compressivo do solo (Faure, 1981; Horn, 1988, Larson et al., 1980; McBride \& Watson, 1990).

O teor e tipo de argila também determinam a profundidade de transmissão e a persistência da compactação. Assim, quanto maior o teor de argila, maior a profundidade a qual a pressão é transmitida e, portanto, maior a espessura da camada compactada (Horn, 1988). Incrementos no teor de argila, principalmente de tipo expansivo, parecem ser efetivos em aliviar os efeitos da compactação. Os processos de contração e expansão que essas argilas experimentam parecem diminuir a persistência da compactação (Hakkansson et al., 1988). 
A resposta dos solos à compactação também é influenciada pelo teor de matéria orgânica do solo (Assouline et al., 1997; Etana et al., 1997; Larson et al., 1980; McBride, 1989; McBride \& Watson, 1990; Guérif, 1990). Soane (1990) assinalou que existem vários mecanismos pelos quais a matéria orgânica influência a capacidade dos solos para resistir às forças de compactação: a) força de união entre partículas e entre agregados, b) elasticidade, c) efeito de diluição, d) efeito nas cargas elétricas, e) efeito na fricção. A susceptibilidade do solo à compactação decresce com o incremento no teo r de carbono orgânico no solo (Guérif, 1990; O’Sullivan, 1992; Soane, 1990; Zhang et al., 1997) devido à redução da faixa de umidade na qual o solo exibe propriedades plásticas (McBride \& Bober, 1989). O efeito da matéria orgânica na redução da compressibilidade parece ser dependente da umidade do solo no momento de aplicação da carga. Soane (1990) indicou que esse efeito é maior para valores elevados de umidade no solo, mas assinalou que os efeitos da matéria orgânica na compressibilidade dos solos não foram bem documentados. Neste sentido, Zhang et al. (1997) concluíram que é necessário determinar a influência do teor de carbono no solo na susceptibilidade à compactação para diferentes solos e condições de umidade.

A umidade do solo é um fator amplamente reconhecido como determinante do processo de compressão dos solos (Soane, 1990; McBride, 1989; McNabb \& Boersma, 1996). Para uma dada condição de textura e teor orgânico, o fator que determina a magnitude da deformação que pode ocorrer no solo é o conteúdo de água no momento da aplicação do estresse (Larson \& Gupta, 1980; Larson et al., 1980; O’Sullivan, 1992; Sánchez-Girón et al., 1998; Soane, 1986). A água no solo atua como lubrificante entre as partículas, permitindo o deslocamento das mesmas. O movimento das partículas do solo é favorecido à medida que a umidade aumenta. Este processo continua até que a água sature praticamente todos os poros do solo. A partir desse momento, a um novo incremento no conteúdo de água, não corresponderá um incremento na densidade, visto que a água não pode ser comprimida (Smith et al., 1997a).

Existe controvérsia entre os autores acerca do efeito do conteúdo de água sobre a susceptibilidade do solo à compactação. Larson et al. (1980) e O'Sullivan (1992) indicaram que esse parâmetro não depende do conteúdo de água no solo, enquanto que 
Sánchez-Girón et al. (1998) demonstraram que a susceptibilidade do solo à compactação foi fortemente correlacionada com a umidade do solo. Essas diferenças parecem estar relacionadas à forma na qual a diminuição do conteúdo de água no solo incrementa o número de contatos entre as partículas, o que por sua vez, depende diretamente da textura do solo (McNabb \& Boersma, 1996).

Poucas variáveis são necessárias para caracterizar o estado de compactação dos solos (Figura 3), sendo as mais importantes o tipo de solo, o teor de carbono orgânico e a umidade no momento de aplicação do estresse. Os Latossolos são solos com predomínio de caulinita, gibbsita, goethita e hematita (Ferreira et al., 1999), e com presença de uma microestrutura particular, caracterizada por agregados de tamanhos milimétricos. Nesses solos, os teores de óxidos de ferro e alumínio e argila podem apresentar uma ampla faixa de variação (Ferreira et al., 1999). Smith et al. (1997a) demonstraram que solos com minerais de argila 1:1 e ricos em óxidos de ferro (Oxisols) apresentaram funcionamento compressivo diferentes, o que foi atribuído às diferenças nos teores de argila e matéria orgânica. Assouline et al. (1997) constataram que Latossolos da região de Cascavel e Palotina (Paraná) também apresentaram respostas à compactação diferentes, apesar de possuir teores de argila semelhantes, o que foi atribuído ao diferente grau de orientação das partículas e teor de matéria orgânica.

Diversas relações entre as propriedades físicas e mecânicas dos solos foram utilizadas para determinar a sua compressibilidade, empregando amostras com estrutura deformada e indeformada, saturadas e não saturadas (Bailey et al., 1986; Larson \& Gupta, 1980; Larson et al., 1980; McNabb \& Boersma, 1993; O’Sullivan et al., 1992). Apesar da falta de padronização no método utilizado, os autores empregaram a curva de compressão dos solos para o entendimento do processo de compressão.

Verificou-se que solos que não experimentaram pressões prévias apresentaram uma curva de compressão linear (Culley \& Larson, 1987; Larson \& Gupta, 1980; Larson et al., 1980; Gupta \& Allmaras, 1987). Entretanto, nos solos que já tinham sofrido a aplicação de cargas externas, a curva de compressão mostrou forma curvilinear, caracterizando-se por apresentar uma parte curva e uma parte reta (Figura 4). O ponto que divide a curva de compressão em suas duas componentes (não linear e linear) é 
chamado pressão de preconsolidação $\left(\sigma_{\mathrm{p}}\right)$. A pressão de preconsolidação divide a curva de compressão em duas regiões: uma de deformações pequenas e recuperáveis (chamada linha ou curva de compressão secundária), e outra de deformações plásticas e não recuperáveis (chamada linha ou reta de compressão virgem).

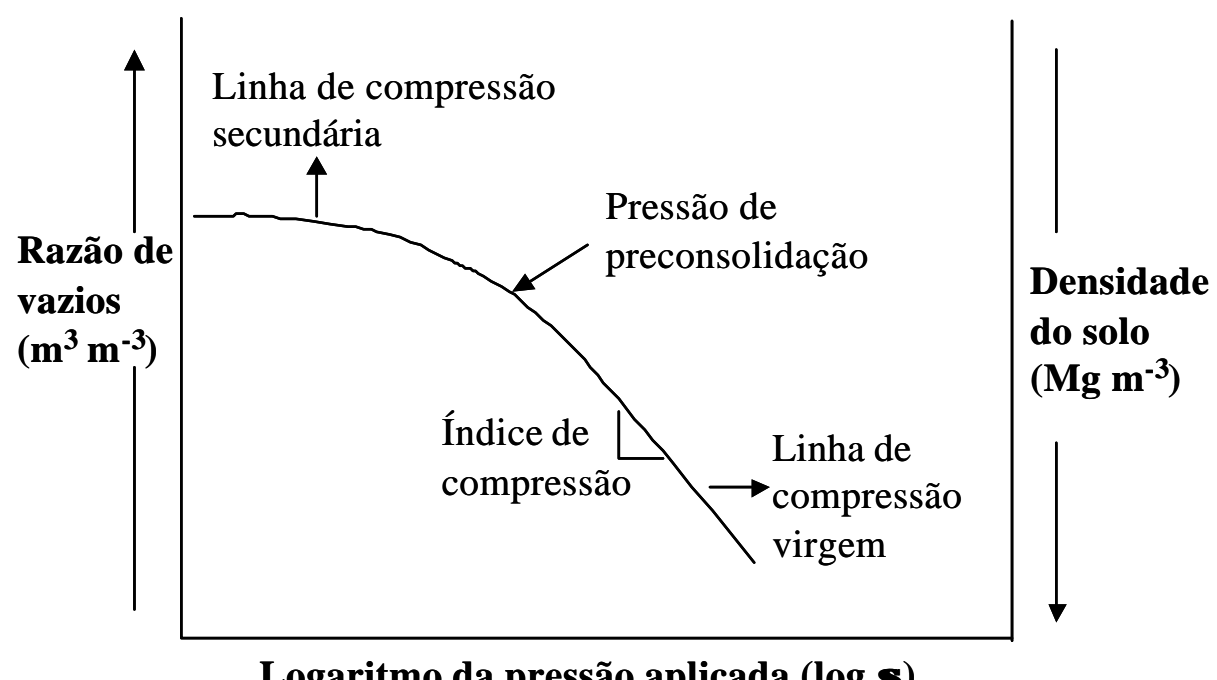

Figura 4 - Curva de compressão do solo (adaptada de Gupta \& Allmaras, 1987)

Estudos sobre a linha de compressão virgem foram desenvolvidos, primeiramente, por Larson et al. (1980). Os autores desenvolveram um modelo linear que permitia estimar a densidade final do solo a partir da pressão aplicada. O coeficiente angular da equação foi chamado índice de compressão. Esse índice indica a taxa de variação da razão de vazios (ou densidade do solo) em resposta à aplicação de determinado estresse, razão pela qual é considerado um indicador da susceptibilidade do solo à compactação.

Gupta \& Allmaras (1989) assinalaram que solos que apresentam valores elevados do índice de compressão exibem grandes mudanças na relação ar-água-matris do solo quando ocorre a aplicação de um estresse, embora esses solos não necessariamente apresentam condições inadequadas para o crescimento das plantas. 
De acordo com Larson et al. (1980), variações no índice de compressão podem ser atribuídas a diferenças no teor de matéria orgânica e tipo de minerais presentes na fração argila. Os autores demonstraram que a susceptibilidade do solo à compactação incrementou linearmente com o teor de argila até o valor de 33\%, permanecendo constante a partir desse valor. Os maiores valores de compressibilidade corresponderam a solos com argila tipo 2:1 e os menores a solos com predominância de caulinita e óxidos de ferro na fração argila.

Outras pesquisas demonstraram que solos com textura grossa foram menos susceptíveis à compactação que solos com textura fina (Horn, 1988; Horn \& Lebert, 1994; McNabb \& Boersma, 1993; McBride \& Joosse, 1996), e solos com mesmo teor de argila resultaram mais susceptíveis à compactação com o decréscimo da densidade do solo inicial (Horn, 1988). No Brasil, várias pesquisas demonstraram que o índice de compressão foi afetado pela densidade do solo, umidade e sistema de uso do solo (Kondo \& Dias Junior, 1999b; Kondo \& Dias Junior, 1999c; Silva et al., 2000; Silva et al., 2002a; Silva et al., 2002b).

Modelos que permitem representar a curva de compressão de solos que já sofreram a aplicação de cargas externas; ou seja, aquelas de forma curvilinear (Figura 4), foram desenvolvidos a partir dos estudos de Larson et al. (1980). Em todos os casos, esses modelos foram de tipo exponencial (Assouline et al. , 1997; Bailey et al., 1986; McBride \& Joosse, 1996; McNabb \& Boersma, 1993; McNabb \& Boersma, 1996; Veenhof \& McBride, 1996). Estes autores assinalaram que a curva de compressão secundária indica a magnitude das pressões suportadas pelo solo no passado. Portanto, é essa parte da curva a que reflete a história de manejo do solo, sendo a pressão de preconsolidação $\left(\sigma_{\mathrm{p}}\right)$ um indicador da maior pressão que o solo suportou no passado. A aplicação de pressões maiores que a pressão de preconsolidação deve ser evitada durante as atividades de preparo do solo para impedir a ocorrência de compactação adicional do solo (Dias Junior \& Pierce, 1995).

Embora vários autores determinaram o valor da pressão de preconsolidação para diferentes classes de solo e sistemas produtivos de regiões de clima temperado (Dias Junior \& Pierce, 1995; Lebert \& Horn, 1991; Veenhof \& McBride, 1996) e 
tropical (Kondo \& Dias Junior, 1999a; Kondo \& Dias Junior, 1999b; Kondo \& Dias Junior, 1999c; Silva et al., 2000; Silva et al., 2002a; Silva et al., 2002b), poucos modelos foram desenvolvidos para estimar esse parâmetro a partir de atributos do solo.

Dias Junior \& Pierce (1995) desenvolveram um modelo não linear, para solos de regiões temperadas, que permite determinar a pressão máxima que o solo pode suportar sem sofrer compactação adicional com base na umidade do solo. Esse modelo foi testado por Kondo (1998) para Latossolos da região de Lavras submetidos a diferentes sistemas de manejo. Nesse estudo o ajuste do modelo foi afetado pelo sistema de manejo utilizado.

Silva et al. (2000), estudando um Latossolo Vermelho-Escuro e um Podzólico Vermelho-Amarelo, verificaram que a pressão de preconsolidação foi função linear da umidade e densidade do solo. Esses autores assinalaram que outros atributos do solo, além da umidade e densidade, poderiam estar interferindo no resultado devido ao reduzido coeficiente de determinação obtido.

Por outro lado, Silva et al. (2002a) avaliaram a pressão de preconsolidação num Latossolo Vermelho distrófico e um Argissolo Vermelho-Amarelo distrófico arênico submetidos a dois sistemas de manejo: plantio direto e convencional. Os autores verificaram que a pressão de preconsolidação variou com o sistema de manejo do solo utilizado, aumentando de forma exponencial com o aumento da densidade do solo, para determinada classe de grau de saturação. Os autores assinalaram que, devido à variação nos resultados encontrados para solos de regiões tropicais, há necessidade de estudos sobre a influência do estado de compactação e conteúdo de água na pressão de preconsolidação, em outras classes de solos e sistemas de manejo.

De acordo com Kayombo \& Lal (1994) e Dias Junior \& Pierce (1996) há necessidade de desenvolver pesquisas básicas e aplicadas que permitam um melhor entendimento do processo de compressão dos solos de regiões tropicais, e integrar essas informações em modelos ou funções que permitam estimar os efeitos da compactação.

A pressão de preconsolidação $\left(\sigma_{\mathrm{p}}\right)$ foi utilizada, especificamente, como indicador da capacidade de carga dos solos parcialmente saturados, uma vez que a aplicação de cargas maiores que esse valor induzem a uma compactação adicional do 
solo e, decorrente disso, à degradação da qualidade estrutural do solo (Lebe rt \& Horn, 1991; Dias Junior \& Pierce, 1996). A compactação (deformação) do solo devida à aplicação de determinada carga pelas máquinas agrícolas induz alterações na estrutura do solo, com aumento da resistência e da densidade do solo (Soane \& Ouwerkerk, 1994).

A resistência, a textura e a densidade do solo também foram utilizadas, isoladamente, como indicadores da qualidade física do solo. No entanto Letey (1985) assinalou que apesar dessas propriedades condicionarem as práticas de manejo na agricultura, elas não estão diretamente relacionadas com a produtividade das culturas. $\mathrm{O}$ autor indicou que o potencial da água no solo, a taxa de difusão de oxigênio, a temperatura e a resistência do solo à penetração das raízes, os quais afetam diretamente o crescimento das plantas, seriam indicadores mais adequados da qualidade física do solo para a produção das culturas.

Silva et al. (1994) propuseram o "Least Limiting Water Range" (LLWR) como um indicador da qualidade estrutural do solo para a produtividade das culturas. Esse indicador integra o efeito do potencial matricial, aeração e resistência do solo à penetração das raízes num único parâmetro, possibilitando estabelecer as condições de umidade do solo limitantes ao crescimento das plantas. O LLWR foi definido como a faixa de conteúdo de água do solo determinada por dois limites: o superior e o inferior. O limite superior do LLWR é a umidade do solo na capacidade de campo ou a umidade do solo na qual a porosidade de aeração é de $10 \%$, e o limite inferior é a umidade no ponto de murchamento permanente ou a umidade do solo na qual a resistência do solo à penetração atinge o valor de 2,0 $\mathrm{MPa}$.

Vários trabalhos demonstraram a capacidade do LLWR para identificar e quantificar alterações na qualidade estrutural de diferentes solos (argilosos, arenosos e de textura franca) e sob diversos sistemas de manejo (plantio convencional, plantio direto, sistemas florestais) (Silva et al., 1994; Silva \& Kay, 1996; Silva \& Kay, 1997a; Silva \& Kay, 1997b; Betz et al., 1998; Zou et al., 2000). 
O termo LLWR foi traduzido no português como "Intervalo Hídrico Ótimo" (IHO) por Tormena et al. (1998). Esses autores avaliaram, por primeira vez no Brasil, o IHO num Latossolo Roxo muito argiloso cultivado no sistema de plantio direto.

Em todos os trabalhos o IHO tem demonstrado ser um indicador mais sensível as variações da condição estrutural dos solos (representadas pelas variações na densidade do solo) do que o parâmetro água disponível.

Pesquisas têm demonstrado que a compactação produz diminuição do IHO (Silva et al., 1994; Silva \& Kay, 1997a; Betz et al., 1998; Tormena et al., 1998). Essa diminuição aumenta a probabilidade das raízes das culturas serem expostas à ocorrência de condições físicas do solo restritivas para o seu crescimento (Kay, 1989). Nesse sentido, Silva \& Kay (1996) verificaram que o crescimento de plantas de milho foi negativamente correlacionado com a frequiência de ocorrência de umidades do solo fora dos limites do IHO.

Embora as pesquisas têm demonstrado que os indicadores $\sigma_{\mathrm{p}}$ e IHO estão relacionados com propriedades como a densidade e umidade do solo, e que a alteração de um deles $\left(\sigma_{\mathrm{p}}\right)$ pode implicar numa redução do outro (IHO), com conseqüente impacto negativo sobre a qualidade física do solo para o estabelecimento e rescimento das culturas, há carência de estudos que relacionem o indicador de capacidade de suporte do solo $\left(\sigma_{\mathrm{p}}\right)$ e o indicador de qualidade física do solo para o crescimento das plantas (IHO).

Em geral, pode-se afirmar que indicadores da qualidade do solo são aqueles atributos que determinam a capacidade do solo para sustentar a produtividade das culturas no longo prazo (Carter et al., 1997). Em algumas situações, esses atributos são facilmente mensuráveis; em outras, são de difícil obtenção. Neste último caso, funções de pedotransferência podem ser de grande ajuda na estimativa desses atributos.

O termo "Funções de Pedotransferência" (FPTs) descreve a relação quantitativa entre propriedades ou indicadores de qualidade do solo (geralmente de difícil obtenção) e seus atributos que são mais facilmente medidos (Bouma, 1989). A distribuição do tamanho das partículas, a densidade do solo, o teor de matéria orgânica, a umidade, o teor de certos componentes da fração argila são alguns dos atributos do solo mais utilizados para gerar FTPs (Wösten et al., 2001). 
Estudos recentes demonstraram que as FPTs podem ser utilizadas para estabelecer a sensibilidade das características estruturais dos solos a mudanças no teor de carbono orgânico, quando submetidos a diferentes níveis de compactação relativa (Kay et al., 1997). Silva et al. (1997) utilizaram FPTs para determinar o efeito do manejo na compactação relativa de solos do Canadá que apresentaram ampla variação de suas características físicas (granulometria e teor de carbono orgânico). McBride \& Joosse (1996) constataram que as FPTs foram úteis para caracterizar o grau de compactação de solos canadenses com ampla variação na composição granulométrica, mineralogia e teor de matéria orgânica. Esses autores indicaram que as FPTs podem ser utilizadas como um indicador da qualidade física do solo a nível regional.

A textura, a umidade e o teor de matéria orgânica são os atributos do solo que mais afetam a trafegabilidade e a condição estrutural ótima para o preparo e o crescimento das plantas. A condição estrutural ótima para o preparo do solo ("workability") resulta da interação implemento agrícola-solo e determina a capacidade do solo, sob certas condições de umidade e estrutura, para reagir à ação do implemento; ou seja, para adquirir a estrutura adequada para a germinação das sementes e o desenvolvimento das plantas. A trafegabilidade resulta da interação solo-roda e determina a performance do veículo em condições de campo (Guérif, 1994).

O incremento na compactação ocasio na melhora na trafegabilidade dos solos, mas piora a condição estrutural ótima para o preparo ("workability") e o crescimento das plantas, visto que quanto maior a compactação, maior a quantidade de energia requerida para fragmentar o solo e mantê-lo numa condição física adequada. Devido ao comportamento oposto dessas propriedades, há a necessidade de determinar a qualidade do solo que menos afete o crescimento das plantas e permita o tráfego adequado das máquinas agrícolas, e de se obter indicadores úteis para orientar as práticas de manejo dos solos (Assouline et al., 1997; Larson et al., 1980; Gupta \& Allmaras, 1987; McBride, 1989; McNabb \& Boersma, 1993; McBride \& Joosse, 1996; O’Sullivan, 1992).

Nesse sentido, a avaliação de indicadores da condição física ótima após o preparo do solo, trafegabilidade e qualidade estrutural dos solos para o crescimento das 
plantas, por meio de funções de pedotransferência que incorporem os atributos físicos que mais os afetam, podem vir a ser de grande utilidade considerando a falta de informação disponível para os solos brasileiros (Dias Junior \& Pierce, 1996; Assouline et al., 1997). 


\section{FATORES RELACIONADOS À RESISTÊNCIA TÊNSIL E A FRIABILIDADE DE LATOSSOLOS VERMELHOS}

\section{Resumo}

A resistência tênsil e a friabilidade são considerados indicadores da qualidade estrutural do solo. Este trabalho testou a hipótese de que a resistência tênsil e a friabilidade de Latossolos Vermelhos são influenciadas pelos seus atributos intrínsecos. A pesquisa foi conduzida numa área cultivada com cana-de-açúcar, no Município Lençóis Paulista, estado de São Paulo. As amostras $(n=25)$ foram coletadas numa toposseqüência composta por os solos Latossolo Vermelho Distrófico psamítico, Latossolo Vermelho Distrófico típico e Latossolo Vermelho Aluminoférrico típico, os quais apresentam ampla variação de textura e teor de carbono. Cada amostra foi constituída por um conjunto de trinta e cinco agregados, coletados na camada superficial do solo (0-15 cm), em que foram avaliados a resistência tênsil (RT), a friabilidade (F), a distribuição de tamanho de partículas, o teor de matéria orgânica, e o teor de óxidos de $\mathrm{Fe}$ e $\mathrm{Al}$ cristalinos e de $\mathrm{Fe}$, $\mathrm{Al}$ e $\mathrm{Si}$ pouco cristalinos. A análise de regressão múltipla revelou uma relação positiva $\left(\mathrm{R}^{2}=0,92\right)$ entre $\mathrm{RT}$ e o teor de argila+silte e matéria orgânica, e que os óxidos de ferro pouco cristalinos foram os constituintes das frações argila+silte que mais influenciaram a RT. Os resultados também indicaram que os solos foram muito friáveis e friáveis, sendo as formas cristalinas de ferro positivamente relacionadas à friabilidade do solo.

Palavras-chave: resistência tênsil, friabilidade, textura, matéria orgânica, Latossolos. 


\section{FACTORS CONTRIBUTING TO THE TENSILE STRENGTH AND FRIAB ILITY OF OXISOLS}

\section{Summary}

Tensile strength and friability are considered useful indicators of soil structural quality. This study hypothesized that tensile strength and friability are strongly influenced by soil intrinsic properties in some Hapludox. This research was conducted on soil samples collected from a sugar-cane farm and sampling sites $(n=25)$ were located along an Hapludox (Oxisols) catena. The transect crossed three soil types: clayey Rhodic Hapludox; loamy Typic Hapludox, and sandy Typic Hapludox. Each sample comprised thirty-five aggregates collected from the top layer. Tensile strength (TS), friability (F), particle size distribution, organic matter, crystalline and poorly crystalline oxides were measured. Multiple regression analysis showed that TS was positively related $\left(\mathrm{R}^{2}=0.92\right)$ with clay+silt content and organic matter, and that poorly crystalline iron oxides were the constituent of clay+silt fractions that most contributed to TS. Results also indicated that the soils were highly friable, with the crystalline iron forms being positively related with soil friability.

Key words: tensile strength, friability, texture, humidity, Hapludox.

\subsection{Introdução}

As práticas de cultivo podem resultar em decréscimo da qualidade do solo para o crescimento das plantas. $\mathrm{O}$ estabelecimento e o crescimento inadequados das plantas têm sido associados à elevada resistência tênsil dos agregados e a valores inadequados de friabilidade dos solos (Ley et al., 1993). A resistência tênsil é definida como o estresse ou frça por unidade de área requerida para fraturar os agregados do solo, quando submetidos à ação de uma pressão (Dexter \& Watts, 2000). A resistência tênsil é considerada um dos mais importantes indicadores da condição estrutural do solo (Dexter \& Kroesbergen, 1985). Por outro lado, a friabilidade tem sido caracterizada como a 
heterogeneidade (variabilidade) da resistência do solo resultante de fraturas e microfissuras presentes no interior dos agregados (Dexter \& Watts, 2000). Este parâmetro também tem sido considerado uma importante propriedade física dos solos agrícolas, visto que a condição de solo friável é uma característica desejável para o estabelecimento de uma cama de semeadura adequada para a germinação das sementes e ancoragem das plântulas (Snyder et al., 1995; Watts \& Dexter, 1998).

A resistência tênsil e a friabilidade do solo são influenciadas por diversos fatores tais como: umidade (Utomo \& Dexter, 1981), teor de argila dispersa em água (Kay \& Dexter, 1992; Barzegar et al., 1994), concentração e composição da solução do solo (Rahimi et al., 2000), ciclos de umedecimento e secamento (Dexter, 1988b; Kay \& Dexter, 1992), teor e mineralogia da fração argila (Kemper et al., 1987; Guérif, 1990, Ley et al., 1993), matéria orgânica do solo (Casuarano, 1993; Perfect et al., 1995; Rahimi et al., 2000) e materiais cimentantes (Kay \& Dexter, 1992; Kay \& Angers, 1999). A influência desses fatores sobre a resistência tênsil e a friabilidade do solo é dependente das condições climáticas, práticas de manejo e características do solo (Kay \& Dexter, 1992; Kemper et al., 1987; Macks et al., 1996; Watts \& Dexter, 1997).

Em regiões tropicais é comum a presença de topossequiências em que as áreas mais elevadas apresentam boa drenagem e as áreas mais baixas (sopé da encosta) possuem drenagem deficiente. Freqüentemente, variações na topografia são um indicativo de mudanças na profundidade do sólum e no grau de intemperismo químico (Anjos et al., 1998) e, em alguns casos, da presença de diferentes classes de solos. Decorrente disso, em solos de regiões tropicais e, especialmente em Latossolos Vermelhos, a fração argila é composta por diversos minerais, principalmente caulinita e/ou gibbsita e óxidos de Fe e/ou Al (Muggler et al., 1999).

Os óxidos de ferro e alumínio são importantes para a agregação do solo. Diversos autores têm enfatizado a capacidade de agregação dos sesquióxidos (PinheiroDick \& Schwertmann, 1996; Igwe et al., 1999; Muggler et al., 1999). Os óxidos de ferro e alumínio possuem um importante papel como agentes de ligação entre as partículas minerais, exercendo forte influência sobre a estrutura do solo por meio do incremento da 
resistência nas linhas de ruptura (Kay \& Angers, 1999). Apesar disso, alguns autores afirmam que os óxidos de ferro nem sempre influenciam a agregação em Latossolos (Desphande et al., 1968; Muggler et al., 1997; Muggler et al., 1999) e que, em alguns casos, o efeito dos sesquióxidos pode ser, principalmente, devido à interação entre a matéria orgânica e os óxidos e/ou o teor de argila (Guérif, 1990; Bartoli et al., 1992a). A matéria orgânica tem sido mencionada como um agente agregante ou desagregante, dependendo de sua composição química e presença de outros materiais cimentantes (Golberg et al., 1990). Apesar da relevância do assunto, existem poucas informações a respeito dos efeitos dos atributos intrínsecos sobre a resistência tênsil e a friabilidade de solos do Brasil.

Este trabalho testou a hipótese de que a resistência tênsil e a friabilidade de Latossolos Vermelhos brasileiros, com ampla variação na composição granulométrica e no teor de carbono orgânico, são fortemente influenciadas pelas características do solo. Nesse sentido os objetivos deste estudo foram: $i$ ) quantificar os indicadores resistência tênsil e friabilidade de agregados naturais provenientes de Latossolos Vermelhos; ii) examinar o efeito da textura, do teor de carbono orgânico e óxidos cristalinos e pouco cristalinos, e das possíveis interações existentes entre eles, na resistência tênsil e friabilidade; iii) desenvolver funções de pedotransferência que permitam estimar esses indicadores a partir de atributos do solo.

\subsection{Material e Métodos}

O presente estudo foi conduzido em uma área localizada no estado de São Paulo, Município de Lençóis Paulista, Brasil (22³7’31”S, 4846’40”W), que tem sido cultivada com cana-de-açúcar nos últimos vinte anos. O clima foi descrito, segundo a classificação de Köepen, como Cwa (subtropical úmido mesotérmico de inverno seco).

O delineamento experimental adotado foi uma transeção com $1410 \mathrm{~m}$ de comprimento, consistindo de 25 pontos de amostragem distanciados entre si de, aproximadamente, $50 \mathrm{~m}$. A transeção abrangeu três tipos de solos, os quais apresentam uma variação progressiva dos atributos químicos e físicos da parte mais elevada (topo da 
encosta) para a parte mais baixa (sopé da encosta) da paisagem. Os solos foram classificados como Latossolo Vermelho Distrófico psamítico, Latossolo Vermelho Distrófico típico, e Latossolo Vermelho Aluminoférrico típico. Todos os solos possuem regime isotérmico.

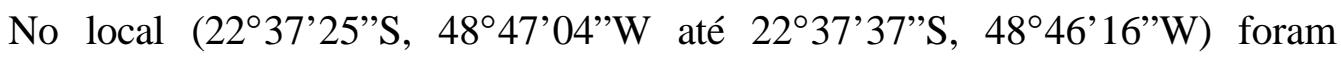
coletados, com auxílio de uma pá, 25 blocos de solo $(15$ x 20 x $15 \mathrm{~cm})$ na camada superficial. No laboratório, as amostras foram secas ao ar e cuidadosamente destorroadas manualmente em seus agregados naturais. Agregados com diâmetro entre 12,5 e 19 mm foram selecionados com o auxílio de duas peneiras. Esta faixa de diâmetro foi escolhida, a princípio, porque seleciona agregados que podem ser desagregados manualmente com maior facilidade e, também, porque esses são os agregados fragmentados pelas operações de preparo do solo que levam à formação de uma cama de semeadura ideal para a emergência e o desenvolvimento das plântulas, a qual é tipicamente composta de agregados com diâmetro entre 1 e 5 mm (Dexter, 1988a). Como os agregados foram obtidos, a partir dos blocos, quebrando progressivamente os torrões em unidades de menor tamanho, em cada estágio a amostra poderia ter sofrido estresse mecânico. Entretanto, foi demonstrado que este método de preparação das amostras não possui efeitos significativos sobre a estrutura ou resistência tênsil de amostras secas ao ar (Grant et al., 1990).

Para a realização das análises, trinta e cinco agregados foram separados de cada bloco (amostra) de solo, totalizando 875 testes individuais ( 25 pontos na transeção x 35 agregados).

O ensaio de tensão indireta foi conduzido para a determinação da resistência tênsil dos agregados. O equipamento (Figura 1), que é equipado com um atuador linear e célula de carga de $20 \mathrm{~kg}$ acoplada a um microcomputador para a aquisição e armazenamento dos dados, aplica a força a uma taxa constante de $0,3 \mathrm{~mm} \mathrm{~s}^{-1}$ até a ruptura do agregado; ou seja, até a formação de uma fissura contínua ao longo do diâmetro polar do agregado.

Os agregados foram pesados individualmente antes da realização dos testes. Em seguida, cada agregado foi colocado, na posição mais estável, entre duas placas, 
sendo a inferior fixa e a superior móvel. A placa superior móvel, ligada à célula de carga, é a responsável pela aplicação progressiva da força sobre o agregado.

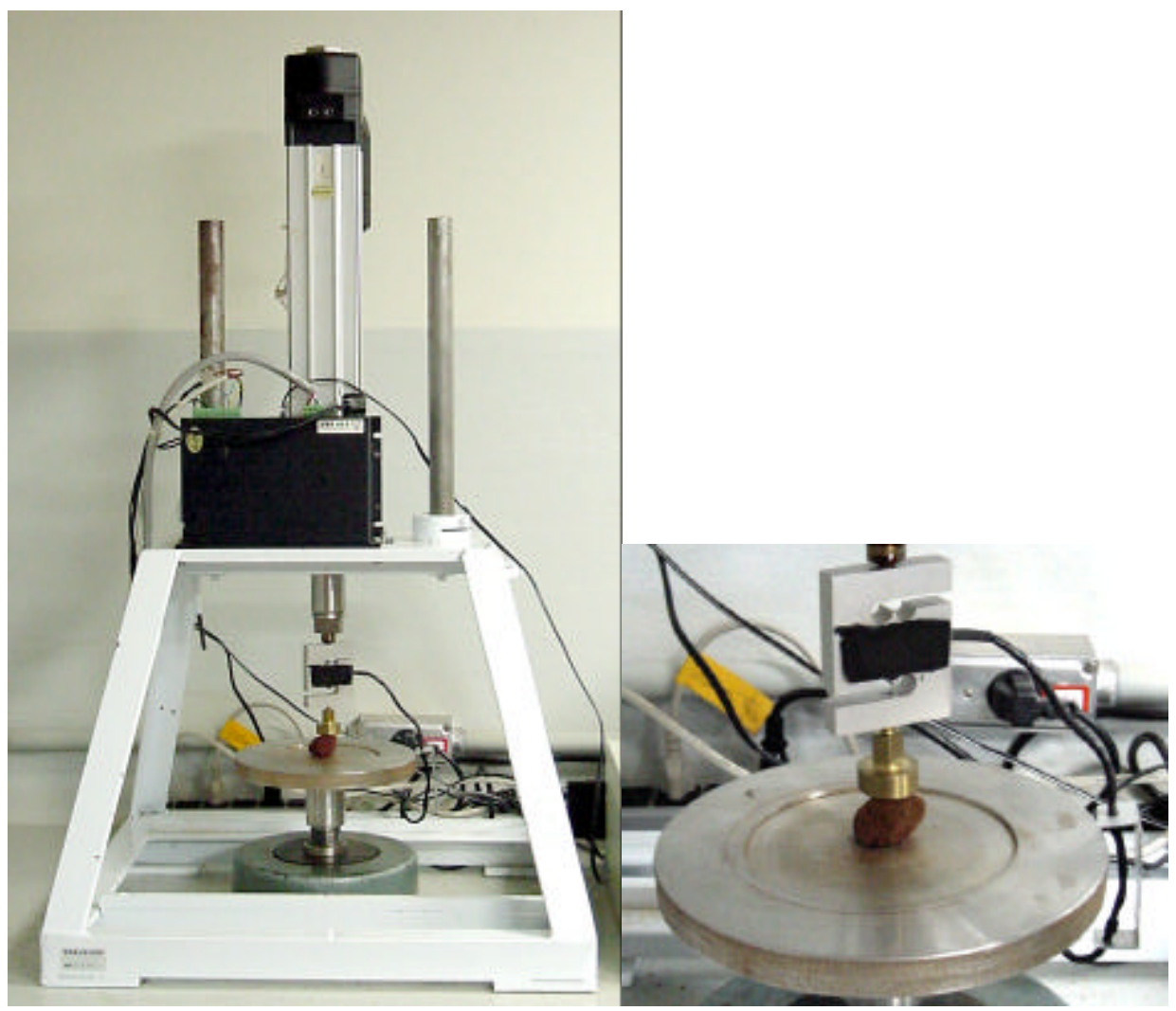

Figura 1 - Equipamento utilizado para a realização dos testes de resistência tênsil.

A resistência tênsil (RT) foi calculada segundo Dexter \& Kroesbergen, (1985):

$$
\mathrm{RT}=0,576 *\left(\frac{P}{D^{2}}\right)
$$

Sendo 0,576 uma constante de proporcionalidade que reflete a relação entre o estresse compressivo aplicado e o estresse tênsil gerado no interior do agregado, $P$ a força aplicada por ocasião da ruptura $(\mathrm{N})$, e $D^{2}$ o diâmetro efetivo de cada agregado $(\mathrm{m})$. 
Devido a sua simplicidade, esta equação tem sido utilizada para estimar a resistência tênsil de agregados naturais de solos franco-arenosos, franco-siltosos, argilosos e muito argilosos (Ley et al., 1993; Macks et al., 1996; Watts \& Dexter, 1998; Chan et al., 1999).

O diâmetro efetivo foi calculado de acordo com a equação proposta por Watts \& Dexter (1998):

$$
\mathrm{D}=\mathrm{D}_{\mathrm{m}} *\left(\frac{M}{M_{0}}\right)^{\frac{1}{3}}
$$

Sendo $M$ a massa de cada agregado (g), $M_{o}$ a média da massa dos agregados que constituíam uma amostra $(\mathrm{g})$, e $\mathrm{D}_{\mathrm{m}}$ o diâmetro médio $(\mathrm{mm})$. $\mathrm{O}$ diâmetro médio dos agregados foi assumido como sendo o diâmetro médio das peneiras $((19+12,5) / 2)$ utilizadas para selecioná-los.

A friabilidade do solo $(\mathrm{F})$ foi calculada através do método do coeficiente de variação proposto por Watts \& Dexter (1998):

$$
F=\frac{\sigma_{\mathrm{Y}}}{\mathrm{Y}} \pm \frac{\sigma_{\mathrm{Y}}}{\mathrm{Y} \sqrt{2 n}}
$$

Sendo: $\sigma_{\mathrm{Y}}$ o desvio padrão dos valores de resistência tênsil medidos, Y a média dos valores de resistência tênsil obtidos e $n$ o número de repetições. O segundo termo é o erro padrão do coeficiente de variação. Este método possui as vantagens de ser aplicável a agregados de tamanho único, e os resultados serem facilmente calculados (Watts \& Dexter, 1998; Macks et al., 1996).

Após a realização dos testes, todos os agregados que constituíam uma amostra (bloco) foram reunidos e utilizados para calcular a umidade do conjunto, secando-os em estufa a $105^{\circ} \mathrm{C}$. Os agregados provenientes de cada bloco foram posteriormente moídos e passados em peneira de $2 \mathrm{~mm}$. As amostras obtidas foram utilizadas para a realização das análises químicas e físicas. Para a determinação da granulometria, as amostras foram dispersas com hexametafosfato de sódio [HMP, $\left(\mathrm{NaPO}_{3}\right)_{\mathrm{n}}$ ] e agitadas por $16 \mathrm{~h}$ em agitador horizontal a 120 ciclos por minuto. A distribuição do tamanho das partículas foi determinada pelo método da pipeta (Gee \& Bauder, 1986). Foram adotados os limites de 
diâmetro de partículas definidos pela classificação da USDA. O teor de carbono foi determinado pelo método de oxidação com dicromato de potássio (Raij et al., 1987). Os óxidos cristalinos $\left(\mathrm{Fe}_{\mathrm{d}}\right.$ e $\left.\mathrm{Al}_{\mathrm{d}}\right)$ foram extraídos com o sistema Na-ditionito-citratobicarbonato (Mehra \& Jackson, 1960), e os óxidos pouco cristalinos $\left(\mathrm{Fe}_{\mathrm{o}}\right.$ e $\mathrm{Al}_{\mathrm{o}}$ ) foram extraídos com oxalato- $\mathrm{NH}_{4}$ (Schwertmann, 1964). O Si foi extraído juntamente com o $\mathrm{Fe}_{\mathrm{o}}\left(\mathrm{Si}_{\mathrm{o}}\right)$. Fe, $\mathrm{Al}$ e Si foram determinados por espectroscopia de absorção atômica.

Análises de regressão múltipla, procedimento de seleção "stepwise" do SAS (Statistical Analysis System Institute, 1991), foram realizadas com objetivo de avaliar a relação entre as características do solo e a resistência tênsil e a friabilidade. Inicialmente, o procedimento "stepwise" foi utilizado para selecionar as variáveis significativas. Em seguida, todas as interações possíveis foram computadas e incluídas como variáveis adicionais no procedimento "stepwise". Nos casos onde os termos de interação foram estatisticamente significativos, a interpretação foi conduzida de acordo com o procedimento utilizado por Aiken \& West (1991). O nível de significância adotado para a seleção de variáveis foi $\mathrm{P}<0,05$. A ocorrência de multicolinearidade foi verificada utilizando-se o FIV (Fator de Incremento da Variância), de acordo com Neter et al. (1989). Este procedimento tem como objetivo evitar a inclusão, no modelo, de variáveis independentes altamente correlacionadas. A normalidade das distribuições, para as variáveis resistência tênsil e friabilidade, foi avaliada com o teste de ShapiroWilk (Statistical Analysis System Institute, 1991).

\subsection{Resultados e Discussão}

Os momentos estatísticos dos atributos do solo analisados são apresentados na Tabela 1. Houve uma grande amplitude de variação nos teores de carbono e argila. Os solos também apresentaram uma ampla variação nos teores de óxidos de $\mathrm{Fe}, \mathrm{Al}$ e $\mathrm{Si}$ (Tabela 1). Essa variabilidade é freqüentemente encontrada em áreas com Latossolos. $\mathrm{O}$ grau de pedogênese é altamente dependente das características das superfícies geomorfológicas (relevo) e do material de origem (Anjos et al., 1998), os quais são uns dos principais fatores responsáveis pelas mudanças seqüenciais nos atributos dos solos 
ao longo do gradiente de inclinação das vertentes. Ao contrário dos resultados encontrados por Utomo \& Dexter (1981) e Perfect at el. (1995), a umidade dos agregados não afetou significativamente os valores de resistência tênsil $(t=1,60$; $\mathrm{P}>t=0,13)$ e de friabilidade $(t=-1,53 ; \mathrm{P}>t=0,14)$. Isto provavelmente se deve ao fato de que os teores de água encontrados neste estudo foram inferiores àqueles medidos por Utomo \& Dexter (1981) e Perfect et al. (1995).

O coeficiente de variação da resistência tênsil foi similar ao encontrado por Dexter \& Kroesbergen (1985). A amplitude de variação da RT é influenciada por fatores tais como a forma dos agregados, a variação na composição do solo ao longo da vertente e, obviamente, a friabilidade do solo.

Tabela 1. Momentos estatísticos para as propriedades do solo estudadas. $\mathrm{N}=25$.

\begin{tabular}{lccccc}
\hline Propriedades do solo & Média & $\begin{array}{c}\text { Desvio } \\
\text { Padrão }\end{array}$ & $\begin{array}{c}\text { Coeficiente } \\
\text { de } \\
\text { Variação }\end{array}$ & Mínimo & Máximo \\
\hline Matéria orgânica $\mathbf{( g ~ k g}^{-1}$ ) & 27,50 & 6,2 & 22,60 & 20,00 & 44,00 \\
Argila (\%) & 43 & 10 & 24 & 17 & 54 \\
Silte (\%) & 8 & 3 & 44 & 2 & 17 \\
Areia (\%) & 49 & 13 & 27 & 35 & 81 \\
Areia Muito Grossa (\%) & 0,24 & 0,09 & 40,80 & 0,03 & 0,41 \\
Areia Grossa (\%) & 1,68 & 0,96 & 57,19 & 0,90 & 4,00 \\
\multicolumn{1}{c}{ Areia Média (\%) } & 11,28 & 4,87 & 43,24 & 6,33 & 22,82 \\
Areia Fina (\%) & 27,96 & 6,92 & 24,79 & 20,01 & 45,87 \\
Areia Muito Fina (\%) & 7,84 & 1,34 & 17,14 & 4,30 & 9,95 \\
Fe-oxalato (\%) & 0,12 & 0,05 & 37,58 & 0,04 & 0,21 \\
Al-oxalato (\%) & 0,19 & 0,03 & 15,48 & 0,12 & 0,23 \\
Si-oxalato (\%) & 0,29 & 0,07 & 25,61 & 0,16 & 0,44 \\
Fe-ditionito (\%) & 6,42 & 1,60 & 24,91 & 2,12 & 8,76 \\
Umidade (kg kg ${ }^{-1}$ ) & 0,06 & 0,03 & 50,74 & 0,01 & 0,13 \\
Resistência tênsil (kPa) & 49,37 & 20,99 & 42,51 & 26,39 & 109,73 \\
Friabilidade & 0,45 & 0,14 & 29,82 & 0,26 & 0,79 \\
\hline & & & & &
\end{tabular}


Utomo \& Dexter (1981) avaliaram a resistência tênsil e a friabilidade de solos franco-arenosos e propuseram um sistema de classificação baseado nos valores de friabilidade obtidos a partir do método do volume dos agregados. Macks et al. (1996) utilizaram este sistema de classificação para avaliar a qualidade da condição estrutural do solo para o estabelecimento de culturas em diferentes classes de solos, incluindo Latossolos. O método do volume estima os valores de friabilidade (F') como sendo a inclinação da reta que relaciona o logaritmo da resistência tênsil com o logaritmo do tamanho do agregado (volume do agregado). Este método produz valores de friabilidade menores que aqueles determinados a partir do método do coeficiente de variação $(\mathrm{F})$. Chan et al. (1999) encontraram uma razão média de $\mathrm{F} / \mathrm{F}$ ' próxima a 2 para solos argilosos. Deste modo, os valores de F'(Utomo \& Dexter, 1981) foram multiplicados por 2 para que pudessem ser comparados com os valores de $\mathrm{F}$ determinados neste estudo.

O sistema de classificação de solos quanto à friabilidade adotado neste trabalho é apresentado na Tabela 2.

Tabela 2. Classificação do solo quanto à Friabilidade (F) de acordo com o método do coeficiente de variação.

\begin{tabular}{ll}
\hline Parâmetro & Classes \\
\hline $\mathrm{F}<0,10$ & Não friável \\
$\mathrm{F}=0,10-0,20$ & Levemente friável \\
$\mathrm{F}=0,20-0,50$ & Friável \\
$\mathrm{F}=0,50-0,80$ & Muito friável \\
$\mathrm{F}>0,80$ & Mecanicamente instável \\
\hline
\end{tabular}

De acordo com o valor médio de friabilidade ( $\mathrm{F}=0,45$, Tabela 1$)$, os solos estudados podem ser classificados como "friáveis". Das vinte e cinco amostras analisadas, dez receberam a classificação "muito friável" e quinze "friável". Valores mais elevados de friabilidade indicam que agregados de maior tamanho possuem menor resistência tênsil que aqueles de menor tamanho e, deste modo, podem ser mais facilmente quebrados em unidades menores e mais resistentes produzindo uma 
distribuição de tamanho de agregados adequada com poucas passagens dos implementos de cultivo. Um solo na condição "friável" requer reduzida intensidade de cultivo para a produção de agregados pequenos e, conseqüentemente, de uma cama de semeadura adequada para germinação e estabelecimento das plantas (Macks et al., 1996). A ocorrência de valores de friabilidade elevados pode ser atribuída aos mesmos fatores que influenciam a amplitude de variação da resistência tênsil (Dexter \& Kroesbergen, 1985).

As variáveis resistência tênsil e friabilidade foram submetidas a testes de normalidade. Os resultados indicaram que a resistência tênsil apresentou distribuição log-normal ( $\mathrm{W}=0,9329 ; \mathrm{P}<\mathrm{W}=0,1014)$, enquanto que a friabilidade apresentou distribuição normal (W=0,9451; $\mathrm{P}<\mathrm{W}=0,1939)$. Skidmore \& Layton (1992) e Perfect et al. (1995) observaram resultados semelhantes aos obtidos neste estudo para a resistência tênsil. Entretanto, Bartoli et al. (1992a) e Dexter \& Watts (2000) encontraram que a resistência tênsil apresentou distribuição normal.

\section{Efeito da textura do solo e teor de matéria orgânica sobre a resistência tênsil}

A influência da textura e do teor de carbono orgânico sobre a resistência tênsil foi avaliada por meio de análise de regressão múltipla. Os resultados são apresentados na Tabela 3.

Tabela 3. Resultados da análise de regressão múltipla para o modelo de resistência tênsil: $\operatorname{lnRT}=\mathrm{a}_{0}+\mathrm{a}_{1} \mathrm{AS}+\mathrm{a}_{2} \mathrm{MO}+\mathrm{a}_{3} \mathrm{ASMO}$

\begin{tabular}{|c|c|c|c|c|}
\hline Parâmetro & $\begin{array}{l}\text { Estimativa } \\
\text { do } \\
\text { parâmetro }\end{array}$ & Erro padrão & $t$ & $\mathrm{P}>t$ \\
\hline $\mathbf{a}_{0}$ & 4,3707 & 0,8510 & 5,14 & 0,0001 \\
\hline $\mathbf{a}_{1}$ & $-0,0209$ & 0,0140 & $-1,47$ & 0,1552 \\
\hline $\mathbf{a}_{2}$ & $-0,0596$ & 0,0340 & $-1,75$ & 0,0939 \\
\hline $\mathbf{a}_{3}$ & 0,0015 & 0,0006 & 2,70 & 0,0134 \\
\hline
\end{tabular}


A equação de regressão é apresentada a seguir:

$$
\ln \mathrm{RT}=4,3707-0,0209 \mathrm{AS}-0,0596 \mathrm{MO}+0,0015(\mathrm{AS} * \mathrm{MO}) \quad \mathrm{R}^{2}=0,92
$$

Sendo: RT a resistência tênsil, AS o conteúdo de argila+silte, MO o teor de matéria orgânica, e $(\mathrm{AS} * \mathrm{MO})$ a interação (argila+silte) x (matéria orgânica). As unidades para essas variáveis são mostradas na Tabela 1.

Os teores de AS e MO foram as variáveis que mais influenciaram a RT. Houve uma interação significativa entre as frações mineral e orgânica do solo. Estes resultados estão de acordo com aqueles encontrados por Perfect et al. (1995). O efeito do teor de AS sobre a RT depende do teor de MO e vice-versa, como mostrado nas equações 5 e 6.

$$
\begin{aligned}
& \partial \ln R T / \partial A S=-0,021+0,0015 * M O \\
& \partial \ln R T / \partial M O=-0,060+0,0015 * A S
\end{aligned}
$$

Para ilustrar a interação, valores de teor de AS e MO foram escolhidos e aplicados na equação 4 para gerar retas de regressão simples. Os valores de AS e MO utilizados foram selecionados segundo o critério de Aiken \& West (1991), sendo: um desvio padrão abaixo da média ( $\mathrm{AS}=38 \%, \mathrm{MO}=20,78 \mathrm{~g} \mathrm{~kg}^{-1}$ ), a média $(\mathrm{AS}=51 \%$, $\mathrm{OM}=27,00 \mathrm{~g} \mathrm{~kg}^{-1}$ ), e um desvio padrão acima da média ( $\mathrm{AS}=64 \%, \mathrm{MO}=32,22 \mathrm{~g} \mathrm{~kg}^{-1}$ ). Os resultados são demonstrados nas Figuras 2 e 3. A Figura 2 mostra a variação da resistência tênsil em função do teor de AS, para diferentes níveis de matéria orgânica.

As retas de regressão simples mostram uma relação positiva entre lnRT e o teor de argila+silte, para os três níveis de matéria orgânica selecionados. Entretanto, para teores de AS reduzidos, um aumento no conteúdo de MO causou um decréscimo no lnRT. Para teores intermediários de AS não houve efeito do conteúdo de MO. Já para os teores maiores de AS, um aumento no conteúdo de matéria orgânica resultou em aumento no $\operatorname{lnRT}$. O teste $t$ foi empregado para verificar se os coeficientes angulares das retas de regressão simples da resistência tênsil em função do teor de argila+silte diferiram de zero. Os resultados indicaram os coeficientes angulares foram diferentes de zero para os três níveis de matéria orgânica $\left(\mathrm{MO}=20,78 \mathrm{~g} \mathrm{~kg}^{-1}: t=3,20 ; \mathrm{p}<0,0043\right.$; $\left.\mathrm{MO}=27,00 \mathrm{~g} \mathrm{~kg}^{-1}: t=8,63 ; \mathrm{p}<0,0001, \mathrm{MO}=32,22 \mathrm{~g} \mathrm{~kg}^{-1}: t=6,26 ; \mathrm{p}<0,0001\right)$. 


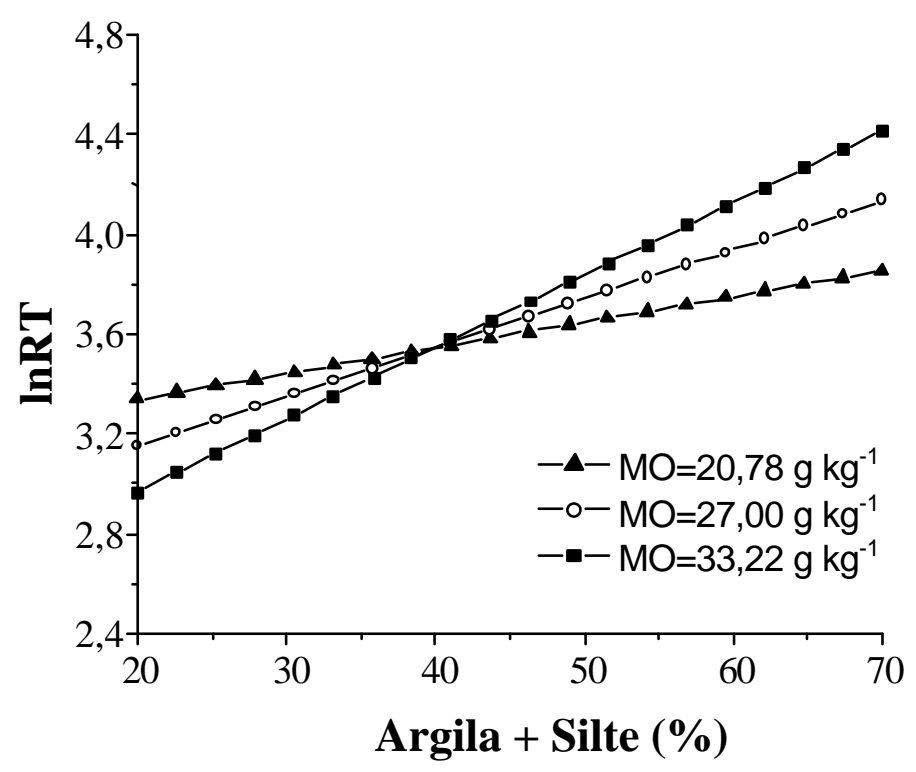

Figura 2 - Variação no lnRT em função do conteúdo de argila+silte considerando três valores de MO: a média $\left(\mathrm{MO}=27,00 \mathrm{~g} \mathrm{~kg}^{-1}\right)$ e $\mathrm{MO} \pm 1 \mathrm{DP}\left(\mathrm{MO}=32,22 \mathrm{~g} \mathrm{~kg}^{-1}\right.$; $\left.\mathrm{MO}=20,78 \mathrm{~g} \mathrm{~kg}^{-1}\right)$.

Diversos autores encontraram um efeito positivo do teor de argila sobre a RT (Kemper et al., 1987; Guérif, 1990; Bartoli et al., 1992a). Entretanto, os mesmos autores não encontraram correlação positiva entre conteúdo de silte e RT. Por outro lado, Ley et al. (1993) e Kay \& Angers (1999) indicaram que o teor de argila dispersa em água e de silte são alguns dos principais fatores que controlam a resistência tênsil dos agregados. As frações argila e silte parecem agir como material agregante entre as partículas maiores, especialmente em solos tropicais fracamente estruturados e com o teor de argila variando de 6 a 45\% (Ley et al., 1993). As partículas menores de solo podem ser mobilizadas de posições onde apresentam um estado de energia maior para posições de menor energia, sendo depositadas principalmente nos pontos de contato ou próximas dos pontos de contato das partículas de maior tamanho, à medida que o solo úmido seca. Nesses locais, os colóides minerais parecem exercer um importante papel na ligação das partículas de maior tamanho. De modo geral, quanto menor a energia livre, maior a resistência tênsil (Dexter, 1988a). 
A resistência tênsil e o teor de matéria orgânica foram positiva e significativamente relacionados, para $\mathrm{AS}=64 \%$ e $\mathrm{AS}=51 \%$ (Figura 3). Entretanto, não houve relação significativa entre a resistência tênsil e o teor de matéria orgânica, para $\mathrm{AS}=38 \%$, como foi demonstrado pelos níveis de significância dos testes $t$ realizados para verificar se os coeficientes angulares das retas de regressão simples diferiram de zero (AS=38\%: $t=-0,20 ; \mathrm{p}<0,8417 ; \mathrm{CS}=51 \%: t=2,42 ; \mathrm{p}<0,0246 ; \mathrm{CS}=64 \%: t=7,79, \mathrm{p}<0,0001)$.

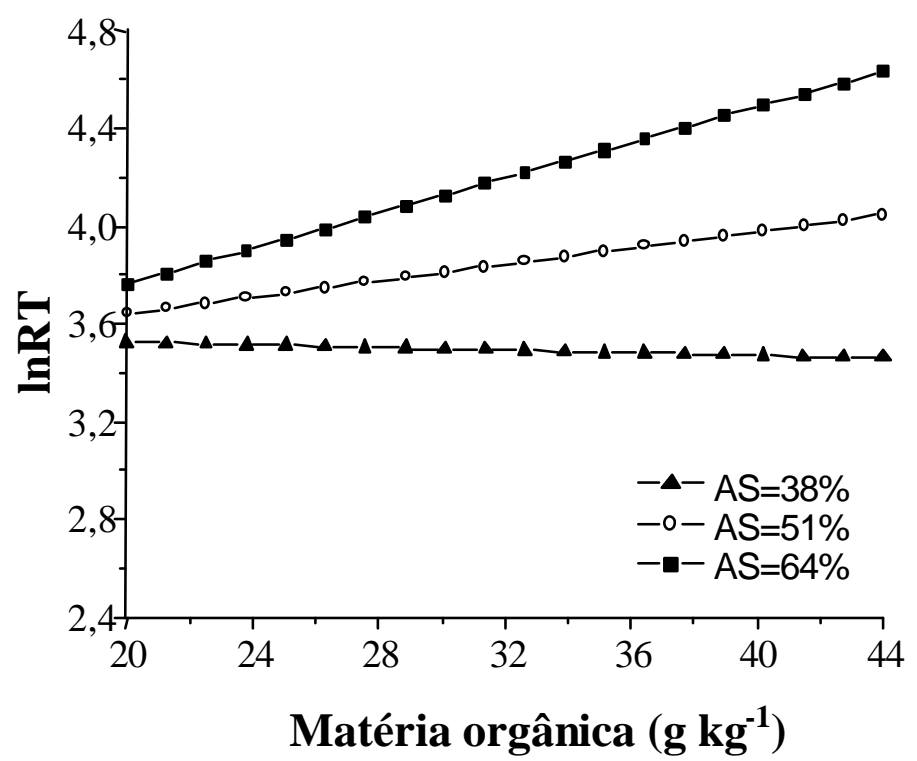

Figura 3 - Variação no lnRT em função do conteúdo de matéria orgânica considerando três valores de $\mathrm{AS}(\mathrm{AS}=51 \%)$ e $\mathrm{AS} \pm 1 \mathrm{DP}(\mathrm{AS}=64 \% ; \mathrm{AS}=38 \%)$.

Os resultados deste estudo permitem explicar porque alguns autores encontraram uma relação positiva entre RT e MO (Bartoli et al., 1992a; Casuarano, 1993; Rahimi et al., 2000), enquanto outros não encontraram relação alguma (Utomo \& Dexter, 1981; Watts \& Dexter, 1998) ou encontraram uma relação negativa (Guérif, 1990; Watts \& Dexter, 1997).

A influência da matéria orgânica sobre as zonas de fissura (superfícies de fraqueza) depende da natureza dessas zonas que, por sua vez, depende da composição química e distribuição espacial da matéria orgânica dentro dos agregados e da textura do 
solo (Kay \& Angers, 1999). Em geral, as partículas de argila dos Latossolos são rígidas, apresentando reduzida mobilidade devido à escassa quantidade de cargas superficiais (Bartoli et al., 1992b). Quando o teor de AS é elevado, a matéria orgânica pode contribuir para o aumento dos valores de RT, visto que a MO pode estabilizar os microagregados ao ser incorporada nos pequenos espaços existentes entre os domínios de argila e "clusters" (aglomerados ou pequenos agrupamentos de partículas de argila) (Dexter, 1988a). Por outro lado, quando o teor de AS é pequeno e o conteúdo de MO é elevado, a matéria orgânica pode causar decréscimo da RT. Caso o comprimento das moléculas orgânicas seja similar ao comprimento do eixo das partículas de argila, a adsorsão específica dos ânions orgânicos pode neutralizar as cargas positivas nos sítios de troca das partículas, deixando-as com excesso de cargas negativas, o que reduz as forças de ligação entre elas. Segundo Kemper et al. (1987) quando grande parte da superfície das partículas minerais são cobertas por ânions orgânicos, essas moléculas reduzem o contato entre as partículas minerais e causam o decréscimo da RT.

\section{Efeito da textura do solo e teor de matéria orgânica sobre a friabilidade}

$\mathrm{O}$ modelo ajustado para resistência tênsil $(\operatorname{lnRT}=\mathrm{f}($ textura do solo, MO) $)$ também foi testado para friabilidade; $\mathrm{F}=\mathrm{f}$ (textura do solo, $\mathrm{MO})(\mathrm{F}=3,13 ; \mathrm{P}>\mathrm{F}=0,054)$. Os resultados mostraram que a friabilidade não foi relacionada com a textura do solo (argila, silte, areia, AS) nem com o teor de matéria orgânica. Esses resultados diferem daqueles encontrados por Macks et al. (1996) e Watts \& Dexter (1998). Esses autores encontraram uma relação positiva entre friabilidade e conteúdo de carbono, o que provavelmente se deveu ao fato desses autores terem utilizado solos com uma faixa de teor de carbono orgânico mais ampla (11 a $59 \mathrm{~g} \mathrm{~kg}^{-1}$ ) daquela verificada neste estudo (20 a $44 \mathrm{~g} \mathrm{~kg}^{-1}$ ). Por outro lado, Macks et al. (1996) encontraram uma baixa correlação entre textura e friabilidade.

No presente estudo, a elevada heterogeneidade textural e estrutural dos solos podem ter sido responsáveis pelos resultados encontrados. A friabilidade é atribuída à presença de fraturas e micro-fissuras no interior dos agregados, e é diretamente 
dependente da quantidade de partículas maiores presentes no solo. Os grãos de areia, não susceptíveis à contração, podem induzir a uma contração diferencial (anisotrópica) da matriz argilosa durante o secamento do solo, resultando em um aumento do número de microfissuras. Por outro lado, quando a fração argila predomina poucas fissuras são formadas, devido a que a matriz argilosa possui a capacidade de contrair-se isotropicamente, fazendo com que as partículas de argila permaneçam em contato com as partículas vizinhas (Towner, 1988).

A forma dos agregados presentes no solo também afeta a friabilidade (Dexter $\&$ Watts, 2000). Em geral, solos com maior teor de areia apresentam agregados com formato mais esférico do que os agregados de solos argilosos, os quais possuem forma prismática (Perfect et al., 1995). Dexter (1985) verificou que os agregados apresentavam formato mais esférico em solos com menores teores de argila e maiores de matéria orgânica. A ampla faixa de textura abordada neste estudo pode ter sido responsável pela variabilidade no formato dos agregados, o que pode ter contribuído para a elevada heterogeneidade dos valores de resistência tênsil.

\section{Efeito dos óxidos e teor de matéria orgânica sobre a resistência tênsil}

Em alguns Latossolos, a resistência tênsil tem sido associada à presença de óxidos de Fe e/ou Al (Pinheiro-Dick \& Schwertmann, 1996; Muggler et al., 1999). Com o objetivo de examinar quais constituintes da fração AS do solo foram responsáveis pela RT, foram realizadas análises de regressão múltipla incluindo as diferentes formas de óxidos (Fe, $\mathrm{Al}$ e $\mathrm{Si}$ oxalato e Fe e $\mathrm{Al}$ ditionito). Os resultados são mostrados na Tabela 4.

O novo modelo para RT, considerando estas variáveis, é apresentado na equação 7.

$$
\operatorname{lnRT}=2,6413+6,4696 \mathrm{Fe}_{\mathrm{o}}+0,0148 \mathrm{MO} \quad \mathrm{R}^{2}=0,92
$$

Sendo: RT a resistência tênsil, $\mathrm{Fe}_{\mathrm{o}}$ o teor de ferro oxalato (\%), e MO o conteúdo de matéria orgânica $\left(\mathrm{g} \mathrm{kg}^{-1}\right)$. 
Tabela 4. Resultados da análise de regressão múltipla para o modelo de resistência tênsil: $\operatorname{lnRT}=\mathrm{a}_{0}+\mathrm{a}_{1} \mathrm{Fe}_{\mathrm{o}}+\mathrm{a}_{2} \mathrm{MO}$

\begin{tabular}{ccccc}
\hline Parâmetro & $\begin{array}{c}\text { Estimativa } \\
\text { do parâmetro }\end{array}$ & Erro padrão & $\boldsymbol{T}$ & P > \\
\hline $\mathbf{a}_{\mathbf{0}}$ & 2,641 & 0,108 & 24,516 & 0,0001 \\
$\mathbf{a}_{1}$ & 6,470 & 0,747 & 8,662 & 0,0001 \\
$\mathbf{a}_{2}$ & 0,015 & 0,005 & 2,738 & 0,0120 \\
\hline
\end{tabular}

$\mathrm{F}=119,57 ; \mathrm{P}>\mathrm{F}=<0,0001 ; \mathrm{R}^{2}=0,92 ; \mathrm{N}=25$.

$\mathrm{Fe}_{\mathrm{o}}=$ ferro oxalato $(\%) ; \mathrm{MO}=$ matéria orgânica $\left(\mathrm{g} \mathrm{kg}^{-1}\right)$.

A resistência tênsil foi significativamente influenciada pelo teor de $\mathrm{Fe}$-oxalato e de matéria orgânica. A análise de regressão mostrou que grande parte da variância na RT foi explicada pelos óxidos de ferro pouco cristalinos $\left(\mathrm{R}^{2}\right.$ parcial $\left.=89 \%\right)$, enquanto que a MO foi responsável por apenas 3\% da variação na RT. A RT foi mais fortemente influenciada pelo $\mathrm{Fe}_{\mathrm{o}}$ do que pela MO. $\mathrm{O}$ efeito agregante da matéria orgânica tem sido mencionado por vários autores (Bartoli et al., 1992a; Casuarano, 1993; Muggler et al., 1999; Rahimi et al., 2000). Entretanto, Igwe et al. (1999) relataram que em solos tropicais, com altos teores de óxidos de $\mathrm{Fe}$ e/ou Al, a contribuição da matéria orgânica para a resistência tênsil do solo pode ser reduzida. A capacidade agregante dos óxidos de ferro foi enfatizada por Pinheiro-Dick \& Schwertmann (1996), Barral et al. (1998), Muggler et al. (1999), e Igwe et al. (1999). Os autores indicaram que os óxidos podem afetar a RT de duas formas: i) agregados podem ser formados pela atração entre as partículas de óxidos de ferro positivamente carregadas e as partículas da matriz negativamente carregadas, principalmente da fração argila, e ii) os óxidos podem formar uma camada sobre a superfície das partículas minerais, servindo como ligação entre diferentes frações (Kay \& Angers, 1999; Muggler et al., 1999). Em ambos os casos, os óxidos de $\mathrm{Fe}$ e/ou $\mathrm{Al}$ podem alterar a carga superficial dos minerais do solo, intensificando as ligações entre as partículas minerais e/ou orgânicas. Como conseqüência, a resistência tênsil do solo aumenta.

A análise de regressão múltipla mostrou que os óxidos de ferro pouco cristalinos foram os constituintes da fração AS do solo que mais influenciaram a RT. A 
semelhança entre os coeficientes de correlação encontrados para os dois modelos (Equações 4 e 7) parece confirmar tal tendência. Resultados semelhantes foram encontrados por Pinheiro-Dick \& Schwertmann (1996) e Muggler et al. (1999). Esses autores relataram que os óxidos de ferro parecem agir como agentes agregantes entre as partículas minerais, preferencialmente entre as partículas da fração silte. Tal comportamento justifica o fato das frações argila e silte terem sido incluídas em conjunto no primeiro modelo (Equação 4). Os resultados aqui apresentados ressaltam a importância de se considerar a fração silte como outro fator afetando a resistência tênsil dos agregados em Latossolos.

\section{Efeito dos óxidos sobre a fri abilidade}

Com o objetivo de verificar se alguma forma específica dos óxidos afetou a friabilidade do solo foram realizadas análises de regressão múltipla empregando o procedimento de seleção "stepwise". Os resultados são apresentados na Tabela 5.

Tabela 5. Resultados da análise de regressão múltipla para o modelo de friabilidade: $\mathrm{Fr}=\mathrm{a}_{0}+\mathrm{a}_{1} \mathrm{Fe}_{\mathrm{o}}+\mathrm{a}_{2} \mathrm{Si}_{\mathrm{o}}+\mathrm{a}_{3} \mathrm{Fe}_{\mathrm{c}}$

\begin{tabular}{ccccc}
\hline Parâmetro & $\begin{array}{c}\text { Estimativa } \\
\text { do } \\
\text { parâmetro }\end{array}$ & Erro padrão & $\boldsymbol{t}$ & $\mathbf{P}>\boldsymbol{t}$ \\
\hline $\mathbf{a}_{\mathbf{0}}$ & 0,341 & 0,112 & 3,054 & 0,006 \\
$\mathbf{a}_{1}$ & $-2,643$ & 0,943 & $-2,849$ & 0,011 \\
$\mathbf{a}_{2}$ & $-0,870$ & 0,317 & $-2,750$ & 0,012 \\
$\mathbf{a}_{3}$ & 0,108 & 0,028 & 3,837 & 0,001 \\
\hline
\end{tabular}

$\mathrm{F}=5,93 ; \mathrm{P}>\mathrm{F}=<0,004 ; \mathrm{R}^{2}=0,46 ; \mathrm{N}=25$.

$\mathrm{Fe}_{\mathrm{o}}=$ ferro oxalato $(\%) ; \mathrm{Si}=$ silício oxalato $(\%) ; \mathrm{Fe}_{\mathrm{c}}=$ ferro cristalino $(\%)$.

O modelo é apresentado na equação 8:

$$
\mathrm{F}=0,341-2,643 \mathrm{Fe}_{\mathrm{o}}-0,870 \mathrm{Si}_{\mathrm{o}}+0,108 \mathrm{Fe}_{\mathrm{c}} \quad \mathrm{R}^{2}=0,46
$$


Sendo: $\mathrm{F}$ o valor de friabilidade, $\mathrm{Fe}_{\mathrm{o}}$ o teor de ferro extraído pelo oxalato de amônio (\%), $\mathrm{Si}_{\mathrm{o}}$ o teor de silício pelo oxalato oxalato de amônio (\%), e $\mathrm{Fe}_{\mathrm{c}} \mathrm{o}$ teor de ferro cristalino $(\%)$.

A friabilidade foi negativamente relacionada com os teores de Fe e Sioxalato, e positivamente com o teor de ferro cristalino. A relação negativa entre $\mathrm{Fe}_{\mathrm{o}}-\mathrm{Si}_{\mathrm{o}} \mathrm{e}$ friabilidade pode estar associada à ação cimentante desses constituintes do solo, o que provoca aumento da resistência tênsil do solo e decréscimo da friabilidade (PinheiroDick \& Schwertmann, 1996). A diferença entre as formas de ferro extraídas por ditionito e as extraídas por oxalato é uma estimativa das formas cristalinas de ferro (Golberg et al., 1990). De acordo com Barral et al. (1998), as formas cristalinas de ferro favorecem a formação de partículas maiores. Pinheiro-Dick \& Schwertmann (1996) também indicaram que os óxidos de ferro com estrutura cristalina, como a hematita e a goethita, podem associar-se à gibbsita, caulinita e quartzo para formar agregados com diâmetro entre 100 e $200 \mu \mathrm{m}$ em solos de clima tropical.

Esses microagregados, muito estáveis em solos tropicais (Muggler et al., 1999), se combinam para formar a próxima ordem hierárquica, os agregados do solo. Agregados de ordens hierárquicas inferiores (menor tamanho) possuem uma resistência interna maior do que agregados de ordens hierárquicas superiores (maior tamanho) (Dexter, 1988a). Estes conceitos explicam porque a resistência tênsil dos agregados decresce com o aumento do tamanho dos agregados. O elevado valor médio de friabilidade obtido neste estudo sugere que a resistência tênsil decresce com o volume do agregado, o que também foi observado por Utomo \& Dexter (1981), sendo as formas cristalinas de ferro o principal fator que afeta a friabilidade do solo.

\subsection{Conclusões}

1. Este estudo confirmou a hipótese de que existe uma relação entre resistência tênsil friabilidade e atributos intrínsecos em Latossolos Vermelhos.

2. O teor de argila+silte, de matéria orgânica e sua interação foram os fatores que mais influenciaram a resistência tênsil dos agregados. 
3. Os óxidos de ferro pouco cristalinos foram os constituintes da fração argila+silte que mais influenciaram a resistência tênsil dos agregados.

4. Os óxidos de ferro cristalinos e pouco cristalinos afetaram a friabilidade do solo, sendo as formas cristalinas as que exerceram maior impacto sobre a friabilidade do solo.

5. Estudos complementares que permitam determinar a influência da mineralogia sobre a resistência tênsil e friabilidade de Latossolos Vermelhos são ainda necessários. Os resultados sugerem que as diversas formas dos óxidos de $\mathrm{Fe}$, $\mathrm{Al}$ e $\mathrm{Si}$ deveriam ser consideradas em estudos futuros para um melhor entendimento do comportamento da resistência tênsil e friabilidade em solos tropicais. 


\section{INFLUÊNCIA DE ATRIBUTOS FÍSICOS NA SUSCEPTIBILIDADE À COMPACTAÇÃO, CAPACIDADE DE SUPORTE DE CARGA E COMPRESSIBILIDADE DE LATOSSOLOS VERMELHOS}

\section{Resumo}

A compactação afeta as propriedades físicas, químicas e biológicas dos solos, sendo considerada uma das principais causas de degradação dos solos agrícolas do mundo. O processo de compactação é influenciado pela estrutura, textura, umidade e teor de matéria orgânica do solo. No Brasil, os solos classificados como Latossolos podem apresentar ampla variação nos atributos físicos. No entanto, modelos que integrem a influência desses atributos na estimativa da compactação são escassos para solos brasileiros. O objetivo geral deste trabalho foi determinar a influência de atributos intrínsecos na susceptibilidade à compactação, pressão de preconsolidação e compressibilidade de Latossolos Vermelhos, e desenvolver funções de pedotransferência que permitam fazer estimativas desses parâmetros a partir de atributos do solo facilmente mensuráveis. $\mathrm{O}$ trabalho foi desenvolvido numa toposseqüência que inclui os solos: Latossolo Vermelho Distrófico psamítico, Latossolo Vermelho Distrófico típico, e Latossolo Vermelho Aluminoférrico típico, com ampla variação de textura e conteúdo de carbono orgânico. As amostras indeformadas de solo $(n=50)$, coletadas na camada 0 0,15 $\mathrm{m}$, foram submetidas a dois potenciais mátricos $(-10 \mathrm{kPa}$ e $-100 \mathrm{kPa})$. Uma vez atingido o equilíbrio efetuou-se o ensaio de compressão uniaxial, em que aplicaram-se as seguintes pressões: 25, 50, 100, 200, 400, 600, 800, 1000, 1300 e $1600 \mathrm{kPa}$. Após a liberação da carga foram determinadas a densidade do solo (Ds) e a umidade com base gravimétrica $(\mathrm{Ug})$. Posteriormente foram avaliadas a granulometria, a densidade de 
partículas e o teor de matéria orgânica do solo. Foram obtidas as curvas de compressão, os valores de índice de compressão (IC) e os valores de pressão de preconsolidação $\left(\sigma_{\mathrm{p}}\right)$. O IC foi significativamente relacionado com a Ds e o teor de argila. O teor de matéria orgânica (MO) e a umidade não afetaram o IC. A $\sigma_{\mathrm{p}}$ foi significativamente relacionada com a Ds, Ug e o teor de argila. O teor de MO não afetou o valor da $\sigma_{\mathrm{p}}$. A compressibilidade do solo foi dependente da Ds. Uma função de pedotransferência (modelo não linear), ajustou significativamente os dados, permitindo estimar o efeito da aplicação de um determinado estresse mecânico na compactação do solo, e orientar a seleção de práticas de manejo que permitam prevenir e/ou diminuir a compactação excessiva dos solos.

Palavras-chave: compressibilidade, compactação, textura, umidade, matéria orgânica.

\section{INFLUENCE OF PHYSICAL ATTRIBUTES ON SUSCEPTIBILITY TO COMPACTION, LOAD SUPPORT CAPACITY AND COMPRESSIBILITY OF HAPLUDOX}

\section{Summary}

Soil compaction affects physical, chemical and biological properties of the soils, and it is considered one of the main causes of the agricultural soils degradation in the world. Compaction process is influenced by soil structure, soil texture, soil organic matter content and soil water content. In Brazil, the soils classified as Hapludox may have a large variation on the ir texture and organic matter content. However, models that integrate the influence of these intrinsic properties on soil compaction are scarce for Brazilian soils. The general goal of this research was to determine the influence of soil intrinsic properties on soil susceptibility to compaction, preconsolidation pressure, and soil compressibility, and to develop pedotransfer functions to estimate these parameteres using easily measurable soil attributes. The work was carried out on a soil toposequence that includes the following soils: clayey Rhodic Hapludox, loamy Typic Hapludox, and sandy Typic Hapludox. These soils have a large variation on their texture and organic 
carbon contents. Undisturbed soil samples (50) were collected on the superficial layer $(0-0,15 \mathrm{~m})$, and submitted to 2 matric potentials $(-10 \mathrm{kPa}$ and $-100 \mathrm{kPa})$. Once the samples reached the equilibrium, the compression uniaxial test was conducted applying the following pressures: 25, 50, 100, 200, 400, 600, 800, 1000, 1300 and $1600 \mathrm{kPa}$. After the load was released, soil bulk density $(\mathrm{Db})$ and moisture $(\mathrm{Wg})$ were determined. Partic le size distribution, particle density, and carbon content (OM) were also evaluated. Soil compression index $(\mathrm{CI})$ and preconsolidation pressure $\left(\sigma_{\mathrm{p}}\right)$ were obtained from the compression curve. IC was significantly related with $\mathrm{Bd}$ and clay content. However, OM and $\mathrm{Wg}$ did not affect IC. $\sigma_{\mathrm{p}}$ was significantly affected by $\mathrm{Bd}, \mathrm{Wg}$, and clay content. OM did not affect $\sigma_{\mathrm{p}}$. Soil compressibility was related to Bd. A non linear model (pedotransfer function) adjusted the data allowing to estimate the effects of mechanical stress application on soil compaction, and to establish guides of management practices that allow to prevent or decrease excessive soil compaction.

Key words: compressibility, compaction, texture, humidity, organic matter.

\subsection{Introdução}

A compactação afeta as propriedades físicas, químicas e biológicas do solo (Hakansson et al., 1988; Hakansson, 1990), e vem sendo considerada uma das principais causas da degradação dos solos agrícolas do mundo (Etana et al., 1997; Hakansson \& Voorhees, 1998; Soane,1986).

A resistência do solo à compactação depende de seus atributos intrínsecos, dentre as quais, a textura é um dos mais relevantes (Hakansson et al., 1988; Horn, 1988; Larson et al., 1980; McBride, 1989). Várias pesquisas indicaram que o teor e o tipo de argila afetam o processo de compressão do solo (Faure, 1981; Horn, 1988, Larson et al., 1980; McBride \& Watson, 1990). Solos com textura grossa são menos susceptíveis à compactação do que aqueles com textura fina (Horn, 1988; Horn \& Lebert, 1994; McNabb \& Boersma, 1993; McBride \& Joosse, 1996).

A resposta do solo à compactação também é influenciada pelo teor de carbono do solo (Assouline et al., 1997; Etana et al., 1997; Larson et al., 1980; McBride, 1989; 
McBride \& Watson, 1990; Guérif, 1990; Soane, 1990). A susceptibilidade à compactação decresce com o incremento do teor de carbono orgânico do solo (Guérif, 1990; O’Sullivan, 1992; Zhang et al., 1997). Entretanto, o efeito da matéria orgânica na redução da compressibilidade parece ser dependente da umidade do solo no momento da aplicação da carga (Soane, 1990).

A umidade do solo é um fator amplamente reconhecido como determinante do comportamento compressivo dos solos (Larson \& Gupta, 1980; Soane, 1986; Soane, 1990; McBride, 1989; O’Sullivan, 1992; McNabb \& Boersma, 1996; Sánchez-Girón et al., 1998). Entretanto, há controvérsia entre os autores sobre o efeito da umidade na susceptibilidade do solo à compactação. Larson et al. (1980) e O'Sullivan (1992) indicaram que a susceptibilidade do solo à compactação não depende do conteúdo de água no solo, contrariando os resultados de Sánchez-Girón et al. (1998), Kondo \& Dias Junior (1999c) e Silva et al. (2000). As diferenças observadas na susceptibilidade do solo à compactação parecem estar relacionadas à forma pela qual a diminuição no conteúdo de água no solo incrementa o número de contatos entre as partículas, o que depende diretamente da textura do solo (McNabb \& Boersma, 1996; Harte, 2000).

No Brasil os solos classificados como Latossolos podem apresentar ampla variação de textura e teor de matéria orgânica. Isso implica em variação de outras propriedades do solo, tais como a densidade do solo e a capacidade de retenção da água, as quais influenciam diretamente a relação compressibilidade-compactação do solo (Etana et al., 1997; Hakansson \& Voorhees, 1998).

Em geral, os autores concordam em empregar a curva de compressão dos solos para o entendimento do processo de compressão (Bailey et al., 1986; Larson \& Gupta, 1980; Larson et al., 1980; McNabb \& Boersma, 1993; O’Sullivan et al., 1992). A curva, que descreve a relação entre a carga aplicada e a razão de vazios (ou densidade do solo), é constituída por duas regiões: uma linear, chamada linha de compressão virgem, cujo coeficiente angular é denominado índice de compressão (Terzaghi \& Peck, 1967), e uma região não linear, a qual resulta da re-compressão de um solo que foi previamente descompactado. O ponto de intercessão das duas regiões da curva é conhecido como pressão de preconsolidação (Casagrande, 1936). A pressão de preconsolidação é 
amplamente aceita como um indicador da história do estresse que o solo suportou no passado e de sua capacidade de suporte de carga (Veenhof \& McBride, 1996), enquanto que o índice de compressão é utilizado como indicador da susceptibilidade dos solos à compactação (Larson et al., 1980).

Funções de pedotransferência (Bouma, 1989) que descrevem quantitativamente a relação existente entre certos atributos do solo, geralmente difíceis de medir, como por exemplo os índices obtidos a partir da curva de compressão, e outros mais facilmente mensuráveis, como a textura, foram desenvolvidos para regiões temperadas com a finalidade de obter indicadores de qualidade do solo (Assouline et al., 1997; Larson et al., 1980; Gupta \& Allmaras, 1987; McBride, 1989; McNabb \& Boersma, 1993; McBride \& Joosse, 1996; O’Sullivan, 1992). McBride \& Joosse (1996) constataram que as funções de pedotransferência foram úteis para caracterizar o grau de compactação de solos canadenses e indicaram que poderiam ser utilizadas como indicadores da qualidade física dos solos em nível regional. Apesar da comprovada utilidade dessas funções, existe pouca informação para os solos das regiões tropicais (Dias Junior \& Pierce, 1996; Assouline et al., 1997).

Este trabalho testou a hipótese de que o comportamento compressivo de Latossolos Vermelhos, com ampla variação nos atributos físicos, poderia ser estimado a partir de funções de pedotransferência. Os objetivos deste trabalho foram: $i$ ) quantificar os indicadores susceptibilidade à compactação, pressão de preconsolidação e compressibilidade do solo; ii) determinar a influência da umidade, matéria orgânica,

textura e densidade do solo nesses indicadores, e iii) desenvolver funções de pedotransferência que permitam estimar a susceptibilidade à compactação, a capacidade de suporte de carga e a compressibilidade de Latossolos Vermelhos a partir de atributos facilmente mensuráveis.

\subsection{Material e Métodos}

O estudo foi desenvolvido numa área cultivada com cana de açúcar, localizada no Município de Lençóis Paulista, no estado de São Paulo (22³7’31’S, 4846’40”W), 
numa topossequiência que inclui os solos: Latossolo Vermelho Distrófico psamítico, Latossolo Vermelho Distrófico típico e Latossolo Vermelho Aluminoférrico típico, os quais apresentam ampla variação de textura e conteúdo de carbono orgânico. O clima foi descrito, segundo a classificação de Köepen, como Cwa (subtropical úmido mesotérmico, de inverno seco).

$\mathrm{Na}$ área, que se encontra sistematizada com terraços para o controle da erosão hídrica, foram estabelecidos 25 pontos de amostragem nas entre linhas da cultura, na camada superficial do solo $(0-0,15 \mathrm{~m})$. Em cada ponto foram retiradas 2 amostras com estrutura indeformada, a partir de anéis volumétricos de $2,5 \mathrm{~cm}$ de altura por $7 \mathrm{~cm}$ de diâmetro, perfazendo um total de 50 amostras.

As amostras foram saturadas com água por 24 horas e divididas em 2 grupos de 25 amostras, sendo cada grupo submetido a um dos seguintes potenciais mátricos $(\psi)$ : -10 e -100 kPa, em câmaras de Richards conforme Klute (1986) com o objetivo de estabelecer um gradiente de umidade.

Após atingir o equilíbrio, as amostras foram submetidas a um ensaio de compressão uniaxial, sendo utilizado o sistema de consolidação automatizado "MCT2000” da SATRON (Figura 1). O deslocamento ocorrido em cada pressão aplicada é registrado por meio de um sensor ligado a um sistema de aquisição de dados.

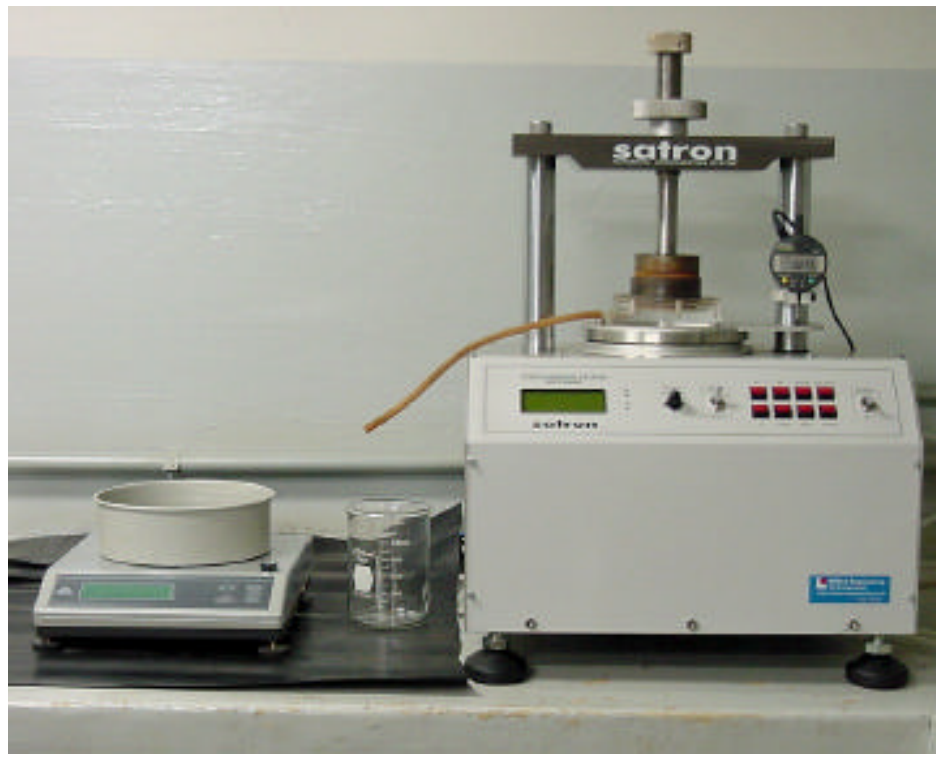

Figura 1 - Equipamento utilizado para a realização dos testes de compressão. 
As amostras foram submetidas aos seguintes valores de pressão: 25, 50, 100, 200, 400, 600, 800, 1000, 1300 e $1600 \mathrm{kPa}$. A carga foi aplicada durante um período de 5 minutos, tempo suficiente para atingir $90 \%$ da deformação máxima (Silva et al., 2000).

Após a liberação da carga, as amostras foram secas em estufa a $105^{\circ} \mathrm{C}$ por 24 horas para a obtenção do valor de massa seca (g) de cada amostra. Os valores de densidade do solo (Ds) foram determinados utilizando-se o valor de massa seca (g) e os valores de volume calculados para cada pressão aplicada, de acordo Hartge (1986). O valor da densidade do solo prévio à aplicação das pressões selecionadas foi denominado densidade inicial do solo.

Posteriormente, as amostras foram moídas e passadas em peneira de $2 \mathrm{~mm}$ para proceder à determinação da granulometria (Gee \& Bauder, 1986), da densidade de partículas (Dp) (Blake \& Hartge, 1986) e do teor de carbono orgânico do solo (Raij et al., 1987). A razão de vazios (RV) foi calculada para cada amostra a partir da densidade do solo e da densidade de partículas ( $\mathrm{RV}=(\mathrm{Dp} / \mathrm{Ds})-1)$ ) (McBride \& Joosse, 1996).

A partir dos resultados foi elaborada, para cada amostra, a curva de compressão do solo num gráfico que relaciona o logaritmo da pressão aplicada $(\sigma)$ (eixo "x") versus a razão de vazios (eixo “y”) (Figura 2).

Para o calculo do valor do índice de compressão (IC) e da pressão de preconsolidação $\left(\sigma_{\mathrm{p}}\right)$ foi desenvolvido um programa dentro do software Mathcad. Na primeira etapa, o programa calcula o ponto de mínima curvatura da curva de compressão. Para isso, é calculada a segunda derivada de cada ponto da curva. O ponto de mínima curvatura é aquele em que a segunda derivada atinge o valor mínimo. Em etapas sucessivas são calculadas (Figura 2) a tangente ao ponto de mínima curvatura (1), a linha horizontal que passa pelo ponto de mínima curvatura (2), a linha bissetriz do ângulo formado entre a tangente e a horizontal ao ponto de mínima curvatura (3), e a linha de compressão virgem (reta calculada usando os últimos 3 pontos da curva de compressão) (4). Por último é calculado o ponto de interseção entre a linha bissetriz e a reta de compressão virgem (5), chamado pressão de preconsolidação $\left(\sigma_{p}\right)$. Dessa forma, a $\sigma_{\mathrm{p}}$ é calculada como proposto por Casagrande (1936), mas sem a subjetividade do 
método manual. A $\sigma_{\mathrm{p}}$ é um indicador da capacidade de suporte do solo. A partir da equação da reta de compressão virgem determina-se o coeficiente angular da reta (6), chamado índice de compressão (IC $=\mathrm{dRV} / \mathrm{d} \log \sigma)$. O IC é um indicador da susceptibilidade do solo à compactação.

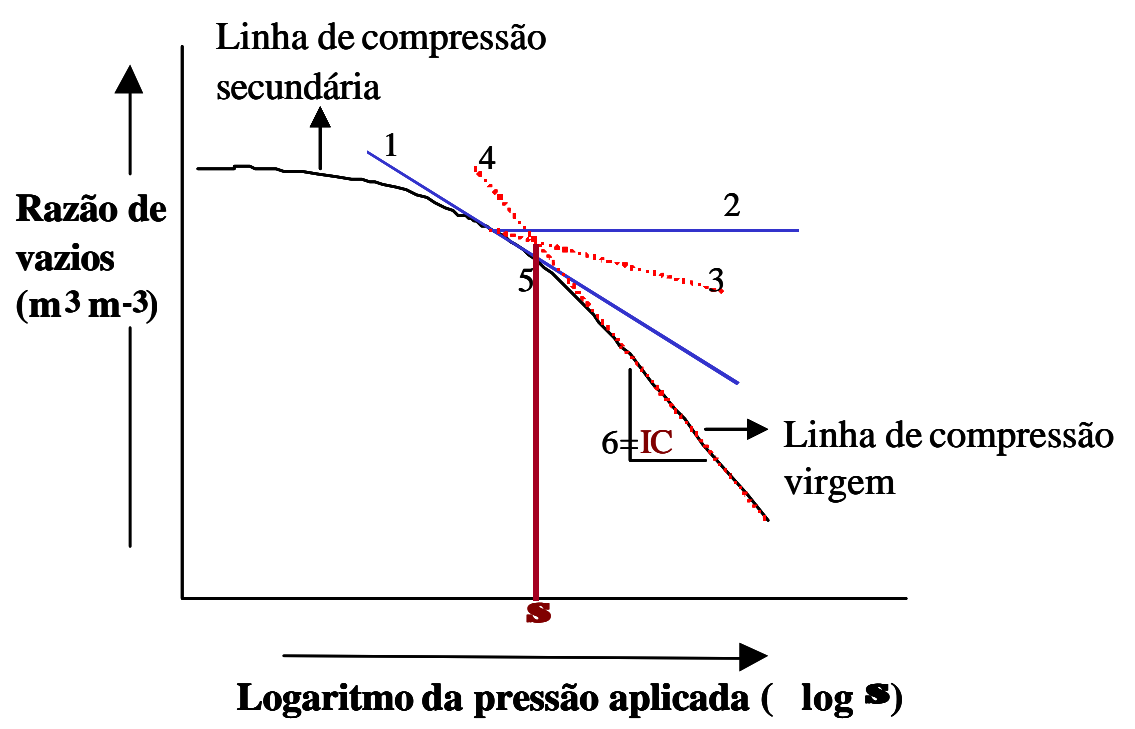

Figura 2 - Curva de compressão do solo com detalhe de: 5- pressão de preconsolidação, e 6- índice de compressão.

O modelo não linear proposto por McNabb \& Boersma (1993) (equação 1) foi utilizado para ajustar os dados das curvas de compressão (consideradas um indicador da compressibilidade do solo). O modelo foi utilizado para estimar o valor de densidade do solo que será atingido quando o mesmo for submetido a uma certa pressão, no intuito de predizer alterações no estado de compactação. O modelo incorpora a influência da condição estrutural do solo, avaliada pela densidade inicial, na estimativa da densidade final $(\rho)$.

$$
\ln \rho=\ln \left(\rho_{0} * \delta \mathrm{i}\right)-(\mathrm{a}+\mathrm{b} * \sigma+\mathrm{c} * \delta \mathrm{c}) *\left(1-\mathrm{e}^{-\mathrm{d}^{*} \sigma}\right)
$$

Sendo: 
$\ln \rho=$ logaritmo natural da densidade final do solo $(\rho)\left(\mathrm{Mg} \mathrm{m}^{-3}\right)$;

$\rho_{0}=$ densidade do solo para o valor de estresse $=0 \mathrm{MPa}\left(\mathrm{Mg} \mathrm{m}^{-3}\right)$;

$\rho \mathrm{i}=$ densidade inicial do solo $\left(\mathrm{Mg} \mathrm{m}^{-3}\right)$;

pmédia = densidade média do solo $\left(\mathrm{Mg} \mathrm{m}^{-3}\right)$;

$\delta \mathrm{i}=\rho \mathrm{i} / \rho$ média;

$\sigma=$ pressão aplicada $(\mathrm{MPa})$;

$\delta c=(\delta \mathrm{i}-1) * \rho_{0}\left(\mathrm{Mg} \mathrm{m}^{-3}\right)$;

a, b, c, d = parâmetros do modelo que descrevem a forma da curva.

$\delta$ i padroniza $\rho_{0}$ para diferenças nos valores da densidade inicial, enquanto $\delta c$ ajusta a curva de compressão completa para diferenças nos valores da densidade inicial do solo de cada amostra.

A influência do conteúdo de água, carbono orgânico, textura e densidade do solo, no índice de compressão, pressão de preconsolidação e compressibilidade foi quantificada por meio de técnicas de regressão linear multivariada e não linear, sendo utilizado o software SAS (Statistical Analysis System Institute, 1991). Os efeitos de multicolinearidade foram testados por meio do FIV (Fator de Incremento da Variância). O FIV é um indicador da magnitude em que a variância dos parâmetros do modelo é incrementada quando as variáveis independentes são altamente correlacionadas, em relação à situação em que as variáveis não são correlacionadas. Valores de FIV menores do que 10 são indicativos de que o efeito multicolinearidade não está influenciando o resultado da regressão (Neter et al., 1989). Nos modelos desenvolvidos neste estudo somente foram incluídas variáveis com valor de FIV menor do que 10.

\subsection{Resultados e Discussão}

Os momentos estatísticos das variáveis analisadas e dos parâmetros obtidos das curvas de compressão são apresentados na Tabela 1. A grande amplitude de variação dos 
atributos físicos e parâmetros estudados pode estar associada ao gradiente de argila presente na topossequiência estudada.

Tabela 1. Momentos estatísticos dos atributos físicos do solo e parâmetros obtidos das curvas de compressão estudadas. $\mathrm{N}=50$

\begin{tabular}{|c|c|c|c|c|c|}
\hline Variável & Média & $\overline{\mathbf{D P}}$ & $\mathrm{CV}(\%)$ & Mínimo & Máximo \\
\hline Matéria orgânica $\left(\mathrm{g} \mathrm{kg}^{-1}\right)$ & 33,26 & 5,53 & 17 & 25,11 & 50,22 \\
\hline Umidade $\left(\mathrm{kg} \mathrm{kg}^{-1}\right)$ & 0,20 & 0,06 & 31 & 0,08 & 0,28 \\
\hline Argila (\%) & 37,26 & 14,13 & 38 & 15,25 & 61,46 \\
\hline Areia $(\%)$ & 50,34 & 20,86 & 41 & 21,58 & 81,81 \\
\hline Silte $(\%)$ & 11,23 & 6,81 & 61 & 1,51 & 23,99 \\
\hline Densidade do solo $\left(\mathrm{Mg} \mathrm{m}^{-3}\right)$ & 1,56 & 0,15 & 10 & 1,26 & 1,82 \\
\hline Densidade de partículas $\left(\mathrm{Mg} \mathrm{m}^{-3}\right)$ & 2,80 & 0,08 & 3 & 2,65 & 2,96 \\
\hline Índice de compressão & 0,209 & 0,043 & 21 & 0,117 & 0,298 \\
\hline Pressão de preconsolidação (kPa) & 138,38 & 78,91 & 57 & 22 & 305 \\
\hline
\end{tabular}

O valor médio da pressão de preconsolidação $\left(\sigma_{\mathrm{p}}\right)$, considerada um indicador da pressão que o solo sofreu no passado pelas máquinas agrícolas, foi similar ao indicado por Kanali et al., (1997) como valor crítico $\left(\sigma_{\mathrm{p}}=122 \mathrm{kPa}\right)$ para solos sob cultura de cana de açúcar. As máquinas agrícolas podem aplicar pressões que variam de 70 a $350 \mathrm{kPa}$, enquanto que equipamentos de transporte podem aplicar pressões de até 600 kPa (Soane, 1986; Kanali et al., 1997; Tijink \& van der Linden, 2000).

O intervalo de variação da pressão de preconsolidação (22-305 kPa) (Tabela 1) sugere que os solos avaliados não foram submetidos a cargas excessivamente elevadas. Isso concorda com o fato de que, na área estudada, vem sendo utilizado equipamento agrícola convencional para o preparo do solo, e a colheita vem sendo efetuada manualmente. Equipamentos de transporte da cana, com elevado peso por eixo e elevada pressão de inflação de ar nos pneus, circulam em áreas restritas, evitando a ocorrência de compactação adicional do solo. 


\section{Influência de atributos físicos na susceptibilidade do solo à compactação}

Os result ados sugerem que o IC aumenta linearmente com o teor de argila até um valor de 30\%, permanecendo relativamente constante a partir desse valor (Figura 2). Larson et al. (1980) observaram comportamento similar do IC. Esses autores, estudando diferentes classes de solos (Alfisol, Ultisol e Oxisol), encontraram relação linear e positiva entre o teor de argila e o IC até o valor de 33\%. A partir desse valor (33\% de argila) o IC se manteve constante. Entretanto, Larson et al. (1980) não avaliaram a influência conjunta do teor de argila e outras propriedades físicas, como por exemplo teor de matéria orgânica e densidade do solo, no índice de compressão.

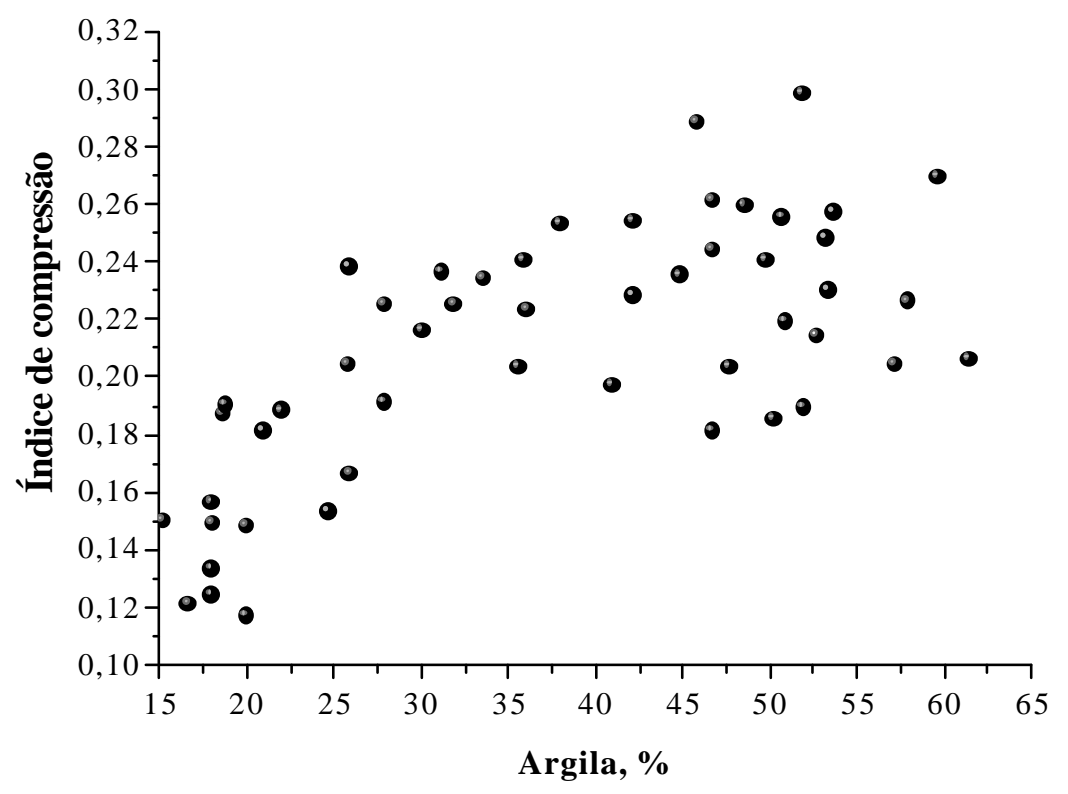

Figura 2 - Índice de compressão versus teor de argila para os solos classificados como Latossolo Vermelho Distrófico psamítico, Latossolo Vermelho Distrófico típico e Latossolo Vermelho Aluminoférrico típico.

A importância relativa da umidade, do teor de matéria orgânica, do teor de argila e da densidade do solo no IC foi determinada por meio de análise de regressão múltipla, utilizando o modelo segmentado linear ("segmented model"; Statistical Analysis System Institute, 1991), já que esse modelo foi o que melhor ajustou aos dados. 
O modelo segmentado estabelece que $y=a+b * x+c * y$ se $x<x_{0}$, e $y=a+b * x_{0}+c * y$ se $\mathrm{x}>\mathrm{x}_{0}$, sendo $\mathrm{x}_{0} \mathrm{o}$ ponto se interseção das duas retas, o qual é calculado pelo modelo. $\mathrm{O}$ resultado é apresentado na Tabela 2. O modelo gerado pode ser escrito como:

$$
\text { IC }=0,248+0,006 * \arg -0,121 * \text { Ds, para } \arg <29,42 \%
$$

$\mathrm{e}$

$$
\mathrm{IC}=0,416-0,121 * \text { Ds, para } \arg >29,42 \%
$$

sendo: $\mathrm{IC}=$ índice de compressão; $\operatorname{arg=argila~(\% );~Ds=densidade~do~solo~}\left(\mathrm{Mg} \mathrm{m}^{-3}\right)$.

\begin{tabular}{|c|c|c|c|c|}
\hline \multirow[t]{2}{*}{ Parâmetro } & \multirow[t]{2}{*}{ Valor estimado } & \multirow[t]{2}{*}{ Erro padrão } & \multicolumn{2}{|c|}{ Interval o de confiança } \\
\hline & & & Limite inferior & Limite superior \\
\hline $\mathbf{a}$ & 0,2481 & 0,0482 & 0,1511 & 0,3451 \\
\hline b & 0,0057 & 0,0012 & 0,0033 & 0,0081 \\
\hline c & $-0,1211$ & 0,0226 & $-0,1666$ & $-0,0755$ \\
\hline $\mathbf{x}_{\mathbf{0}}$ & 29,42 & 2,0019 & 25,38 & 33,45 \\
\hline
\end{tabular}

Tabela 2. Resultados da análise de regressão múltipla para o índice de compressão.

$\mathrm{F}=161,18, \mathrm{P}>\mathrm{F}=0,0001, \mathrm{R}^{2}=0,77 ; \mathrm{x}_{0}=29,42 \%$; patamar $=0,2399$.

O intervalo de confiança dos coeficientes $a$, b e c não incluem o valor zero, possibilitando afirmar que o IC foi significativamente relacionado com o teor de argila e com a densidade do solo (Glantz \& Slinker, 1990). O modelo explicou 77\% da variabilidade dos dados. Os resíduos (valor observado menos valor estimado) foram normalmente distribuídos, segundo o teste de Shapiro-Wilk (W=0,98; $\mathrm{P}<\mathrm{W}=0,73$ ), indicando que o modelo ajustou adequadamente os dados (Neter et al., 1989). Concordando com os resultados de Larson et al. (1980) e O'Sullivan (1992), a umidade e o teor de matéria orgânica não influenciaram significativamente o IC. Já Kondo \& Dias Junior (1999b,c), Zhang et al. (1997) e Silva et al. (2000) obtiveram resultados contrários aos deste estudo. A diferença nos resultados pode ser atribuída ao fato de que aqueles autores avaliaram a influência da umidade e do teor de matéria orgânica 
individualmente e a que, neste estudo, a amplitude do intervalo de variação desses atributos do solo foi menor.

Para ilustrar o efeito da textura e da Ds no IC, três valores de Ds (média, dois desvios padrão acima da média e dois desvios padrão abaixo da média) foram empregados para calcular IC, utilizando as equações 1 e 2 . O resultado é mostrado na Figura 3.

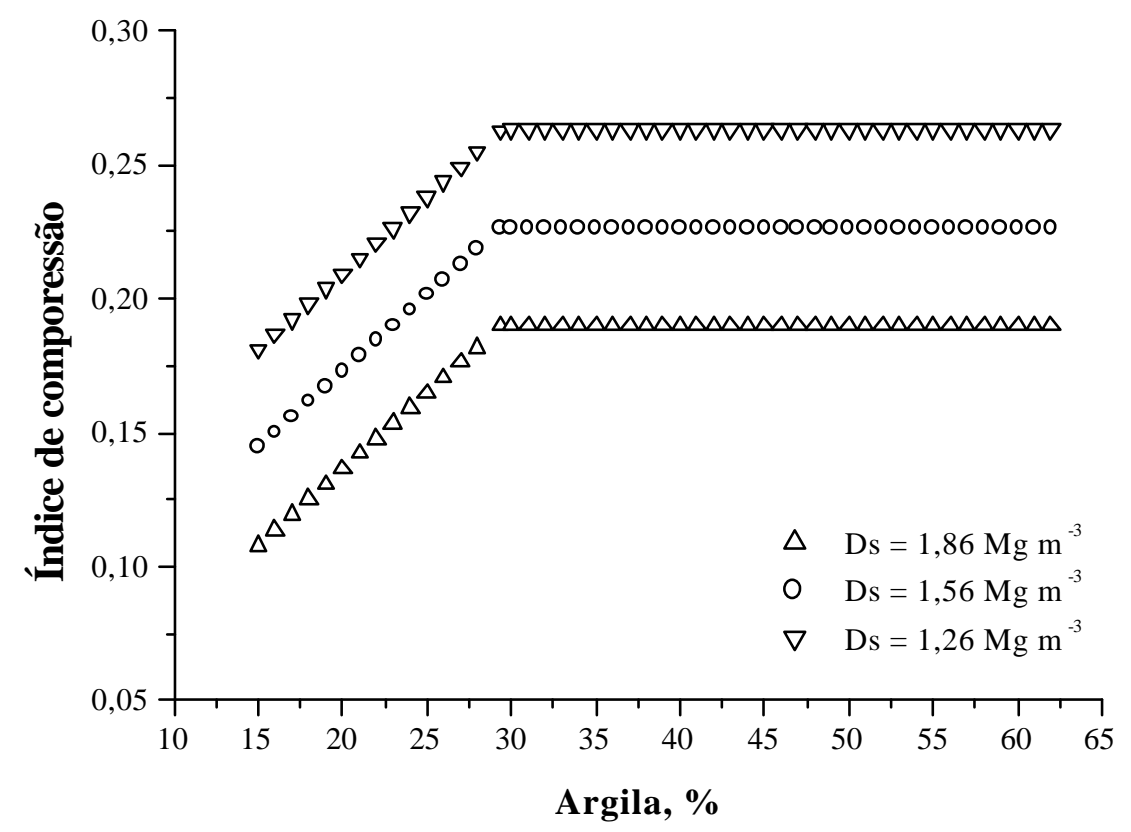

Figura 3 - Valores do índice de compressão em função do conteúdo de argila para três valores de densidade do solo (Ds+2DP, Ds média, Ds-2DP) calculados pelas equações 1 e 2 .

O IC aumentou com o incremento do conteúdo de argila do solo até o valor aproximado de $30 \%$, permanecendo constante a partir desse valor. Resultados similares foram obtidos por Larson et al. (1980), Lebert \& Horn (1991), Veenhof \& McBride (1996) e Smith et al. (1997b). A textura determina o tipo, a forma e a distribuição do tamanho das partículas do solo e, como consequiência disso, o número de contatos entre elas, controlando, assim, a resistência do solo à deformação (Harte, 2000). Larson et al. (1980) indicaram que solos que possuem mais do que 33\% de argila são constituídos, 
basicamente, por uma matriz argilosa, estando o material grosso (grãos de areia) disperso nessa matriz, razão pela qual o IC se manteria constante a partir desse valor.

A diferença entre o valor absoluto de IC no patamar determinado neste estudo $(\mathrm{IC}=0,24)$ e o valor obtido por Larson et al. (1980) $(\mathrm{IC}=0,46)$ pode ser atribuída ao fato de que aqueles autores incluíram, no estudo, diferentes ordens de solos (diferentes mineralogias) e utilizaram amostras com estrutura deformada. Valores de IC semelhantes ao obtido neste estudo foram determinados por Kondo \& Dias Junior (1999b,c) e Silva et al. (2000) em Latossolos, utilizando amostras com estrutura indeformada.

A densidade do solo afetou negativamente o IC. Portanto, quanto maior a Ds menor será a susceptibilidade do solo à compactação. A deformação do solo ocorre quando algumas partículas, individualizadas (cristais) ou agrupadas (domínios), possuem a capacidade de separar-se e movimentar-se em relação a outras. Esse movimento é restringido pelas forças de fricção e pelas ligações existentes entre as partículas. Quanto mais denso o solo e mais intrincado o arranjo das partículas, menor é o espaço poroso disponível para a movimentação das partículas e maiores são as forças de fricção entre elas. Assim, o deslocamento e rearranjamento das partículas sólidas para posições de maior proximidade (deformação) se torna mais difícil a medida em que a Ds é mais elevada (Guérif, 1994; Paz e Guérif, 2000). Resultados semelhantes aos deste estudo foram determinados por Culley \& Larson (1987), Lebert \& Horn (1991), Veenhof \& McBride (1996), Silva et al. (2000) e Silva et al. (2002a).

A partir da Figura 3 pode-se inferir que Latossolos com textura mais grossa (predomínio da fração areia) serão menos susceptíveis à compactação que aqueles que apresentem predomínio da fração argila na composição granulométrica. Resultados similares foram determinados para outros solos (Horn, 1988; Horn \& Lebert, 1994; McNabb \& Boersma, 1993; McBride \& Joosse, 1996). A Figura 3 mostra, também, que para um determinado conteúdo de argila, o solo será mais susceptível à compactação à medida em que a densidade diminui, tal como foi assinalado por Horn (1988). Assim, solos que potencialmente possuem maior qualidade estrutural, associada à menor densidade do solo e/ou maior conteúdo de argila, serão os mais susceptíveis à 
degradação. Portanto, cuidados maiores, no que se refere ao momento oportuno de realização das atividades de preparo do solo e ao emprego de equipamento agrícola adequado, serão necessários para manter a qualidade física do solo que permita otimizar a produtividade das culturas.

\section{Influência de atributos físicos na capacidade de suporte do solo}

O efeito da umidade, matéria orgânica, textura e densidade do solo na pressão de preconsolidação $\left(\sigma_{\mathrm{p}}\right)$ foi determinado por meio de análise de regressão múltipla. $\mathrm{O}$ resultado é mostrado na Tabela 3.

O modelo explicou $70 \%$ da variância dos dados, apresentando os resíduos distribuição normal (W=0,98; $\mathrm{P}<\mathrm{W}=0,46)$. A pressão de preconsolidação foi significativa e positivamente relacionada com a Ds e com o teor de argila, e negativamente com a umidade do solo. O conteúdo de matéria orgânica não influenciou significativamente a $\sigma_{\mathrm{p}}$.

Tabela 3. Resultado da análise de regressão mú ltipla para o modelo $\sigma_{\mathrm{p}}=\mathrm{a}+\mathrm{b} * \mathrm{Ds}+\mathrm{c} *$ $\arg +\mathrm{d} * \mathrm{Ug}$.

\begin{tabular}{crrrrr}
\hline Parâmetro & $\begin{array}{c}\text { Valor } \\
\text { estimado }\end{array}$ & DP & $\boldsymbol{t}$ & P > $\boldsymbol{~}$ & Vif \\
\hline a & $-566,764$ & 93,630 & $-6,05$ & 0,0001 & 0 \\
b & 442,891 & 49,433 & 8,96 & 0,0001 & 1,47 \\
c & 4,338 & 1,777 & 3,68 & 0,0006 & 8,02 \\
d & $-773,057$ & 299,105 & $-2,58$ & 0,0130 & 8,89 \\
\hline
\end{tabular}

$\mathrm{F}=39,85 ; \mathrm{P}>\mathrm{F}=0,0001 ; \mathrm{R}^{2}=0,70$.

Ds=densidade do solo $\left(\mathrm{Mg} \mathrm{m}^{-3}\right)$; arg=argila $(\%)$, Ug=umidade com base gravimétrica $\left(\mathrm{kg} \mathrm{kg}^{-1}\right)$.

Relação positiva entre $\sigma_{\mathrm{p}}$ e densidade do solo foi indicada por Lebert \& Horn (1991); Alexandrou \& Earl (1998); Canarache et al. (2000), Silva et al. (2000) e Silva et al. (2002a). Embora Lebert \& Horn (1991), Alexandrou \& Earl (1998) e Silva et al. 
(2000) não incorporaram a variável argila no modelo por eles determinado, os autores assinalaram que a relação entre $\sigma_{\mathrm{p}}$ e densidade do solo foi dependente da textura. Lebert \& Horn (1991) assinalaram que a influência da Ds como variável independente diminuiu com o incremento no conteúdo de argila.

Em geral, os autores concordam em assinalar que o efeito da Ds na pressão de preconsolidação é devido ao aumento nas forças de fricção entre as partículas, enquanto que a influência da argila é atribuída às forças de coesão entre as mesmas. As forças de coesão dificultam a separação e o deslocamento das partículas do solo, incrementando a sua capacidade de suporte de carga. A Tabela 3 indica que quanto maior o teor de argila e a densidade do solo, para um determinado valor de umidade, maior será a sua capacidade de suporte de carga. Esses solos poderão suportar uma pressão maior pelas máquinas agrícolas, antes de sofrer deformação irreversível, do que aqueles que apresentam teor de argila reduzido.

Embora o incremento do teor de argila tenha um efeito positivo na capacidade de suporte de carga dos solos, deve-se ressaltar que, uma vez ultrapassado esse valor $\left(\sigma_{\mathrm{p}}\right)$, os solos que apresentam maior teor de argila serão os mais susceptíveis à compactação (maior IC, equação 2 e 3). Portanto, cuidados adicionais deverão ser considerados para não exceder os valores de $\sigma_{\mathrm{p}}$ na medida que o teor se argila aumenta.

Por outro lado, a capacidade de suporte de carga do solo $\left(\sigma_{\mathrm{p}}\right)$ diminuiu linearmente com o incremento da Ug. A água forma uma película ao redor das partículas sólidas do solo. O aumento da espessura dessa película, que ocorre com o incremento de umidade, induz à diminuição das forças de ligação entre as partículas. Como conseqüência, a capacidade de suporte de carga do solo é reduzida. Esse comportamento foi observado por vários autores (Horn \& Lebert, 1991; Veenhof \& McBride, 1996; Alexandrou \& Earl, 1998; Kondo \& Dias Junior, 1999a; Silva et al. 2002b). A influência positiva da Ds e negativa do grau de saturação na $\sigma_{\mathrm{p}}$ também foi mencionada por Silva et al. (2000) para um Latossolo Vermelho-Escuro.

A Figura 4 ilustra o efeito do teor de argila e da Ds para três valores de umidade na $\sigma_{\mathrm{p}}$. Os valores de $\mathrm{Ug}$ adotados foram: na capacidade de campo $\left(\mathrm{Ug}_{\mathrm{cc}}=0,20\right.$ 
$\left.\mathrm{kg} \mathrm{kg}^{-1}\right)$, um desvio padrão acima da $\mathrm{Ug}_{\mathrm{cc}}\left(\mathrm{Ug}=0,26 \mathrm{~kg} \mathrm{~kg}^{-1}\right)$ e um desvio padrão abaixo da $\mathrm{Ug}_{\mathrm{cc}}\left(\mathrm{Ug}=0,14 \mathrm{~kg} \mathrm{~kg}^{-1}\right)$.

Em todos os casos, a capacidade de suporte de carga diminuiu com o incremento de umidade, concordando com os resultados de Horn \& Lebert (1991), Veenhof \& McBride (1996), Alexandrou \& Earl (1998), Kondo \& Dias Junior (1999a) e Silva et al. (2002b).

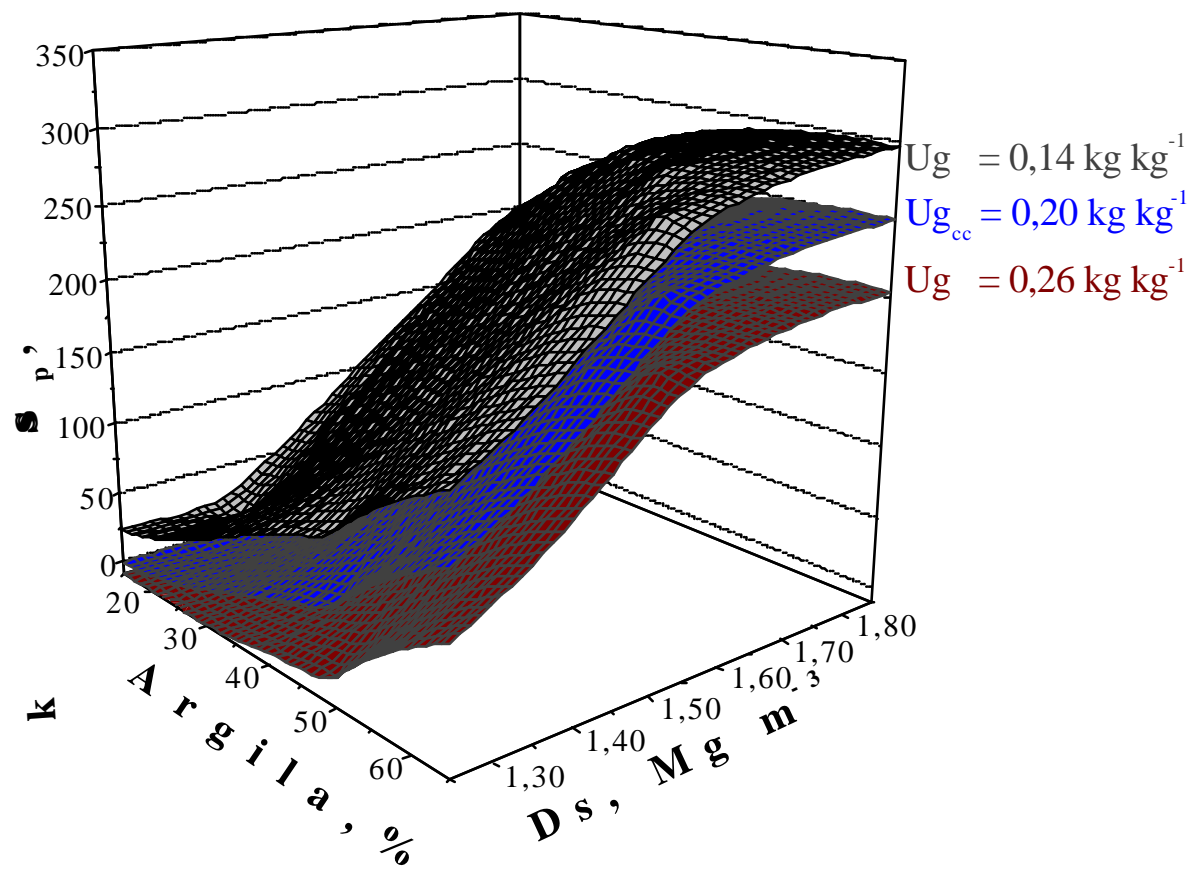

Figura 4 - Pressão de preconsolidação $\left(\sigma_{\mathrm{p}}\right)$ em função do teor de argila e densidade do (Ds) para três conteúdos de água: Ug na capacidade de campo $\left(\mathrm{Ug}_{\mathrm{cc}}=0,20 \mathrm{~kg} \mathrm{~kg}^{-1}\right)$, um desvio padrão acima de $\mathrm{Ug}_{\mathrm{cc}}\left(\mathrm{Ug}=0,26 \mathrm{~kg} \mathrm{~kg}^{-1}\right)$, e um desvio padrão abaixo da $\mathrm{Ug}_{\mathrm{cc}}\left(\mathrm{Ug}=0,14 \mathrm{~kg} \mathrm{~kg}^{-1}\right)$.

Para o valor de $\mathrm{Ug}=0,26 \mathrm{~kg} \mathrm{~kg}^{-1}$, a capacidade de suporte foi menor que 120 $\mathrm{kPa}$ praticamente para toda a amplitude de variação do teor de argila e densidade do solo. $\mathrm{Na} \mathrm{Ug}_{\mathrm{cc}}$, a $\sigma_{\mathrm{p}}$ foi inferior a $120 \mathrm{kPa}$ para valores de Ds menores que $1,6 \mathrm{Mg} \mathrm{m}^{-3} \mathrm{e}$ conteúdos de argila menores que $45 \%$, indicando que solos com textura mais grossa e que tenham sido descompactados por atividades de preparo (menor Ds) sofrerão 
facilmente compactação adicional. Considerando que máquinas agrícolas utilizadas no cultivo da cana de açúcar aplicam, em média, pressões de 120 kPa (Kanali et al., 1997; Tijink \& van der Linden, 2000), cuidados deverão ser observados no que se refere ao momento oportuno de realização das atividades de preparo do solo (umidade do solo adequada) para não induzir compactação adicional.

O secamento do solo aumentou a sua capacidade de suporte de carga. $\mathrm{Na}$ condição de $\mathrm{Ug}=0,14 \mathrm{~kg} \mathrm{~kg}^{-1}$, os solos resistiriam às pressões exercidas pelas máquinas agrícolas sem sofrerem compactação adicional. Porém, não resistiriam ao tráfego de caminhões e carretas agrícolas que, devido às características de peso por eixo e pressão de inflação de ar dos pneus, aplicam pressões elevadas no solo. Equipamentos com valores de peso por eixo de $60 \mathrm{kN}$ e pressão de inflação de ar dos pneus de $180 \mathrm{kPa}$ são muito utilizados para o transporte de cana de açúcar (Kanali et al., 1997).

Droogers et al. (1996) assinalaram que existe, para cada solo, um teor de água ótimo para a realização das atividades de preparo e tráfego de máquinas agrícolas. Esse valor ótimo é definido como o estado de umidade, expresso como teor de água ou potencial mátrico, no qual é possível efetuar operações de preparo ou tráfego sem ocasionar deterioração da estrutura do solo. Se o solo estiver mais seco, atividades de preparo poderão ser efetuadas sem causar compactação adicional, embora a energia requerida será maior.

Por outro lado, solos com predomínio da fração argila possuem maior capacidade de suporte do que aqueles que apresentam predomínio da fração areia, para a faixa de umidade estudada, ainda que apresentando menores valores de Ds (Figura 4). Resultados similares foram determinados por Kondo \& Dias Junior (1999a) e Silva et al. (2002 b) para Latossolos e Argissolos.

Os resultados sugerem que, em toposseqüências com ampla variação do teor de argila, as atividades de preparo deveriam ser realizadas levando em consideração a umidade ótima para os solos com menor teor de argila, os quais possuem menor capacidade de suporte, a fim de evitar a ocorrência de deformação irreversível e, como conseqüência, a degradação da qualidade estrutural do solo. 


\section{Influência de atributos físicos na compressibilidade do solo}

Conhecer o comportamento compressivo dos solos é essencial para predizer as alterações que podem ocorrer na sua estrutura do solo, quando o mesmo é submetido a estresse por implementos agrícolas (McBride, 1989).

A equação 1 foi utilizada para ajustar os dados das curvas de compressão das amostras no intuito de conhecer a compressibilidade dos solos estudados. Os valores dos parâmetros do modelo, obtidos por meio de regressão não linear, são apresentados na Tabela 4.

Tabela 4. Resultados da regressão não linear para o modelo: $\ln \rho=\ln \left(\rho_{0} * \delta i\right)-(a+b *$ $\sigma+\mathrm{c} * \delta \mathrm{c}) *\left(1-\mathrm{e}^{-\mathrm{d} * \sigma}\right)$

\begin{tabular}{ccccc}
\hline Parâmetro & Valor estimado & Erro padrão & \multicolumn{2}{c}{ Intervalo de confiança } \\
& & & Limite inferior & Limite superior \\
\hline $\boldsymbol{\rho}_{\mathbf{0}}$ & 1,5670 & 0,0054 & 1,5564 & 1,5775 \\
$\mathbf{a}$ & $-0,1439$ & 0,0071 & $-0,1578$ & $-0,1299$ \\
$\mathbf{b}$ & $-0,0540$ & 0,0057 & $-0,0653$ & $-0,0427$ \\
$\mathbf{c}$ & 0,4440 & 0,0130 & 0,4184 & 0,4696 \\
$\mathbf{d}$ & 6,1679 & 0,5539 & 5,0796 & 7,2562 \\
\hline
\end{tabular}

$\mathrm{F}=1161,98 ; \mathrm{P}>\mathrm{F}=\left\langle 0,0001 ; \mathrm{R}^{2}=0,90 ; \mathrm{N}=550\right.$.

O modelo explicou $90 \%$ da variabilidade dos dados de densidade do solo, sendo todos os parâmetros significativos (Glantz \& Slinker, 1990). Segundo o teste de Shapiro-Wilk (W), os resíduos (valor observado menos valor estimado para cada valor de pressão aplicado) foram normalmente distribuídos $(\mathrm{P}>0,10)$, indicando que o modelo ajustou adequadamente os dados (Neter et al., 1989).

As Figuras 5 e 6 mostram as curvas de compressão medidas e a estimadas, para uma amostra com textura média (argila=18\%) e uma com textura argilosa (argila=54\%), respectivamente. 


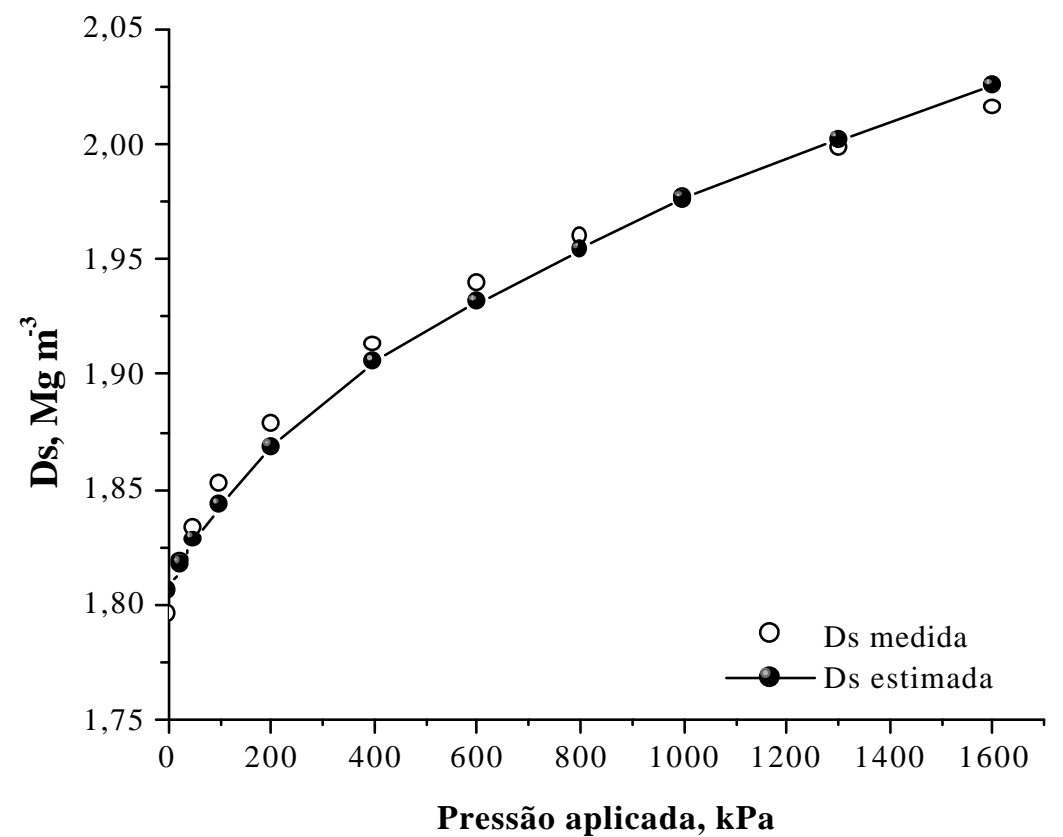

Figura 5 - Curva de compressão medida e estimada para o solo Latossolo Vermelho Distrófico psamítico.

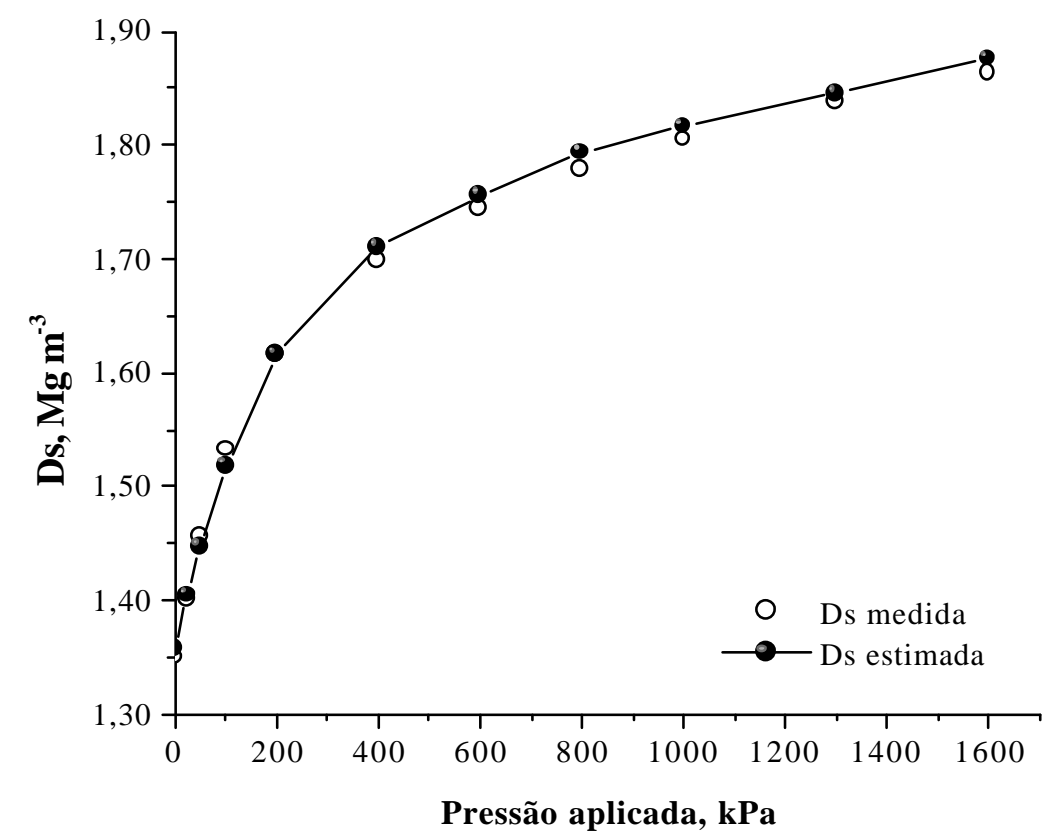

Figura 6 - Curva de compressão medida e estimada para o solo Latossolo Vermelho Aluminoférrico típico. 
O modelo estimou com precisão a densidade do solo para toda a faixa de pressões aplicadas, o que sugere que pode ser utilizado para estimar o estado de compactação (Ds final) a ser atingido quando uma determinada pressão for aplicada, para condições de umidade similares as do presente estudo (menores que a umidade na capacidade de campo).

Apesar da aparente complexidade do modelo, para utilizá-lo na área estudada, somente é necessário determinar a densidade do solo, propriedade que pode ser obtida com facilidade e baixo custo, sendo possível predizer com razoável precisão a densidade do solo que será atingida ao se aplicar determinada pressão (carga) ao solo.

Diversas pesquisas têm demonstrado que as máquinas agrícolas e os equipamentos de transporte possuem pesos que variam entre 10 e $150 \mathrm{kN}$, e utilizam pressões de inflação de ar nos pneus que variam entre 50 e $800 \mathrm{kPa}$. Como conseqüência disso, esses equipamentos aplicam pressões no solo que variam entre 50 e $850 \mathrm{kPa}$ (Soane et al., 1981a; Soane et al., 1981b; Koolen et al., 1992; Vermeulen \& Perdok, 1994; Kanali et al., 1997). A Figura 7 mostra os valores de Ds estimada pelo modelo proposto considerando uma ampla variação de densidade inicial do solo e de pressão aplicada pelas máquinas agrícolas.

Solos com valores iniciais de Ds reduzidos sofrerão maior deformação que solos com valores de Ds elevados. Soane et al. (1981a) e Soane et al. (1981b) assinalaram que solos soltos sofrerão maior deformação que solos com Ds mais elevada, e que o maior incremento de Ds é induzido durante a primeira passada das máquinas agrícolas. Estes resultados ressaltam a importância de controlar o peso das máquinas agrícolas e de utilizar pneus com baixa pressão de inflação, para evitar a deterioração da qualidade física do solo, especialmente na primeira passada e em solos que foram descompactados pelas atividades de preparo. A utilização de valores reduzidos de pressão de inflação de ar dos pneus (menores que $100 \mathrm{kPa}$ ) foi indicada como uma das medidas mais eficientes para o controle da compactação em solos agrícolas (Soane et al., 1981a; Soane et al., 1981b; Kanali et al., 1997). 


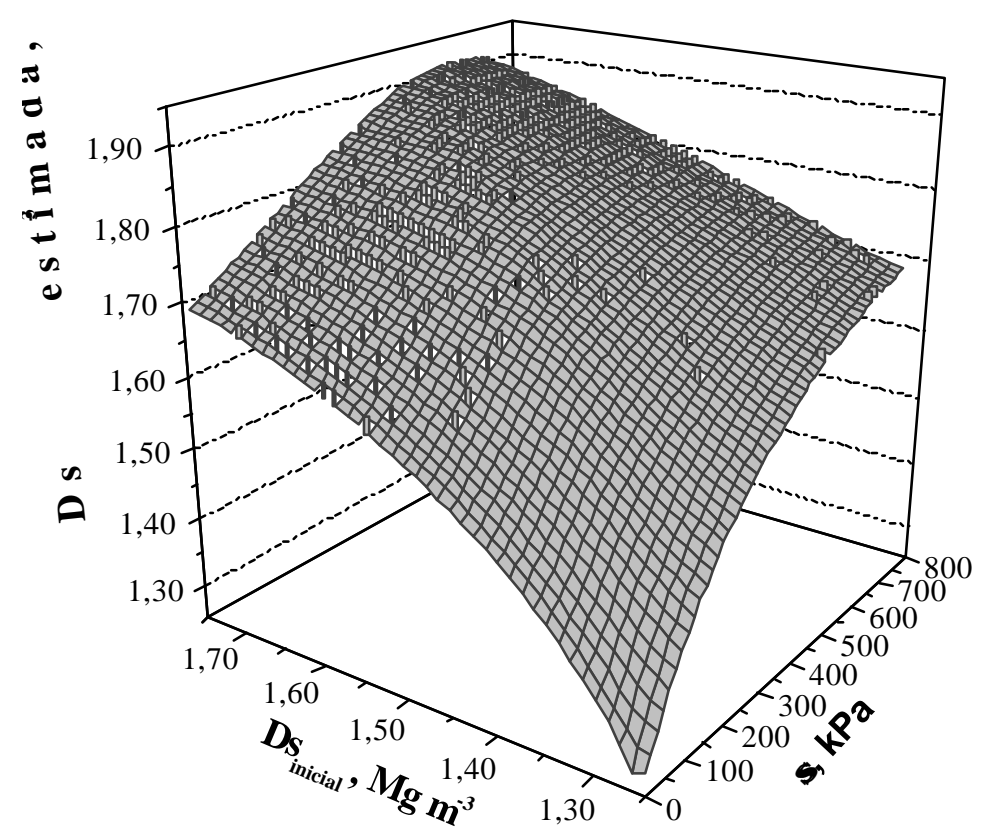

Figura 7 - Valores de densidade do solo estimados por meio da equação 6 em função da densidade inicial do solo (Ds inicial $)$ e pressão aplicada ao solo $(\sigma)$.

Estudos têm demonstrado que a produtividade das culturas é comprometida quando os valores de densidade crítica do solo (definida como a Ds em que ocorrem limitações ao desenvolvimento de plantas associadas à qualidade física do solo) são superados (Silva \& Kay, 1997a; Hakansson \& Lipiec, 2000). Nesse sentido, o modelo poderá ser uma ferramenta muito útil, uma vez que a densidade final do solo poderá ser estimada a partir da determinação da densidade inicial e do conhecimento das pressões que serão aplicadas ao solo pelos implementos agrícolas utilizados. O modelo permitirá predizer se a densidade crítica do solo será superada. Adicionalmente, o modelo poderá ser utilizado como base para a tomada de decisão na escolha do tipo de implemento agrícola (capacidade de carga, pressão de inflação de ar dos pneus) a ser utilizado em cada situação.

Por outro lado, se o modelo for resolvido para o valor da pressão de preconsolidação $\left(\sigma_{\mathrm{p}}\right)$, será possível conhecer o valor de densidade do solo que não deverá ser superado (Ds máxima) para evitar a ocorrência de deformações plásticas e, portanto, irreversíveis do solo. A partir do conhecimento desse valor (Ds máxima) e do 
monitoramento da densidade do solo será possível identificar as práticas de manejo mais adequadas à cada situação.

\subsection{Conclusões}

1. Este trabalho confirmou a hipótese de que o comportamento compressivo de Latossolos Vermelhos, com ampla variação nos atributos físicos, pode ser estimado a partir de funções de pedotransferência.

2. O índice de compressão (IC) aumentou linearmente com o teor de argila até o valor de $29,42 \%$, permanecendo constante a partir desse valor. O IC foi negativa e linearmente influenciado pela densidade do solo em toda a faixa de amplitude de variação do teor de argila. Entretanto, o IC não foi afetado pelo teor de matéria orgânica e umidade do solo.

3. A pressão de preconsolidação $\left(\sigma_{\mathrm{p}}\right)$ foi positivamente influenciada pela densidade do solo e o teor de argila, e negativamente pela umidade do solo. O teor de matéria orgânica não alterou os valores de $\sigma_{\mathrm{p}}$.

4. A compressibilidade dos Latossolos Vermelhos foi dependente da condição estrutural do solo, especificamente do seu estado de compactação inicial. Um modelo não linear, que incorpora a influência da densidade inicial na estimativa da densidade final do solo, demonstrou ser adequado para predizer o comportamento compressivo de Latossolos Vermelhos que possuem ampla variação textural e estrutural, quando submetidos a cargas externas. 


\section{QUANTIFICAÇÃo dE PRESSÕES CRÍTICAS PARA O CRESCIMENTO DAS PLANTAS}

\section{Resumo}

A compactação é uma das principais causas de degradação dos solos agrícolas, tendo sido avaliada por meio de diversos indicadores: (i) de qualidade estrutural do solo para o crescimento das plantas, como o intervalo hídrico ótimo (IHO), e (ii) de capacidade de suporte de carga do solo, como a pressão de preconsolidação $\left(\sigma_{\mathrm{p}}\right)$. Este trabalho foi realizado com o objetivo de relacionar o IHO e a $\sigma_{\mathrm{p}}$, e determinar valores de pressões críticas (Pcr) que possam ser aplicados ao solo sem induzir condições restritivas ao crescimento das plantas, nem compactação adicional do solo. $\mathrm{O}$ estudo foi conduzido com amostras de solo classificado como Argissolo Vermelho Amarelo, cultivado com cana de açúcar, no município de Piracicaba (SP). Na camada superficial do solo foram coletadas trinta e seis amostras com estrutura indeformada para a quantificação do IHO e da $\sigma_{\mathrm{p}}$. A partir do IHO foi obtido o valor de densidade do solo crítica (Dsc) para o crescimento das plantas. A $\sigma_{\mathrm{p}}$ foi linearmente relacionada com a densidade e umidade do solo permitindo a incorporação dos valores de Dsc e do IHO para a quantificação de Pcr. Os resultados indicaram que a Pcr diminuiu linearmente com o incremento da umidade, variando de $360 \mathrm{kPa}$ a $500 \mathrm{kPa}$ para a faixa de umidade de $\theta=0,18 \mathrm{~m}^{3} \mathrm{~m}^{-3}$ a $\theta=0,12 \mathrm{~m}^{3} \mathrm{~m}^{-3}$. O parâmetro proposto permitiu definir valores de pressões máximas que podem ser aplicadas ao solo, para diferentes umidades, sem promover a degradação da qualidade estrutural do solo para o crescimento das plantas. Palavras-chave: compactação do solo, pressão de preconsolidação, intervalo hídrico ótimo, pressões críticas. 


\section{QUANTIFICATION OF CRITICAL PRESSURES FOR PLANT GROWTH}

\section{Summary}

Compaction is one of the main causes of degradation of agricultural soils and it has been evaluated through indicators of: (i) soil structural quality for crop growth, such as the least limiting water range (LLWR), and (ii) load support capacity of the soil, i.e., the preconsolidation pressure $\left(\sigma_{\mathrm{p}}\right)$. This research was carried out with the objective of relating the LLWR and the $\sigma_{\mathrm{p}}$, as well as to determine critical pressures values that can be applied to the soil without inducing restrictive conditions to plant growth as well as additional soil compaction. The study was conducted with soil samples of an Alfisol cultivated with sugarcane from Piracicaba, State of São Paulo (Brazil). Thirty six undisturbed soil samples were taken at the superficial layer to quantify the $\sigma_{\mathrm{p}}$ and the LLWR. Soil critical bulk density (Dbc) was obtained from the LLWR. The $\sigma_{\mathrm{p}}$ was a linear function of the water content and soil bulk density allowing the incorporation of Dbc and LLWR for quantifying the Pcr. The results indicated that Pcr decreased linearly with soil water content, varying from $360 \mathrm{kPa}$ to $500 \mathrm{kPa}$ for the soil water range from $\theta=0,18 \mathrm{~m} \mathrm{~m}^{3}$ to $\theta=0,12 \mathrm{~m}^{3} \mathrm{~m}^{-3}$. The results allowed to define values of maximum pressures that can be applied to the soil, for different water contents, without promoting degradation of soil structural quality for plant growth.

Key words: soil compaction, preconsolidation pressure, least limiting water range, critical pressures values.

\subsection{Introdução}

A compactação afeta as propriedades e funções físicas, químicas e biológicas do solo (Hakansson et al., 1988), sendo uma das importantes causas da degradação dos solos agrícolas no mundo (Hakansson \& Voorhees, 1998).

Em solos compactados ocorre alteração da estrutura, da densidade do solo, da porosidade total, do tamanho e continuidade dos poros (Dexter, 1988a; Horn \& Lebert, 
1994). Decorrente disso, o movimento e armazenamento da água, ar e calor também podem ser afetados, tendo sido verificados aumentos nas perdas de nutrientes por volatilização e lixiviação (Hakansson \& Voorhees, 1998). A redução na capacidade de infiltração de água do solo, devido à compactação da camada superficial, pode resultar em aumento do escorrimento superficial e erosão (Kayombo \& Lal, 1994). A compactação dos solos também pode reduzir a eficiência de utilização de fertilizantes e herbicidas pelas culturas, devido ao menor desenvolvimento radicular das plantas, aumentando os custos de produção (Hakansson \& Voorhees, 1998).

O estado de compactação do solo tem sido avaliado por meio de diversos parâmetros físicos, tais como a densidade do solo (Campbell, 1994), porosidade total, relação de vazios (Veenhof \& McBride, 1996), densidade relativa (Hakansson, 1990; Silva et al., 1997), resistência do solo à penetração das raízes (Silva et al., 1994) e pressão de preconsolidação (Dias Junior, 1994; McBride \& Joosse, 1996; Kondo \& Dias Junior, 1999a), entre outros.

A pressão de preconsolidação $\left(\sigma_{\mathrm{p}}\right)$ tem sido utilizada como indicador da capacidade de suporte de carga dos solos parcialmente saturados, uma vez que a aplicação de cargas maiores que esse valor induzem a uma compactação adicional do solo (Lebert \& Horn, 1991; Dias Junior \& Pierce, 1996). Römkens \& Miller (1971) assinalaram que solos que apresentam valores elevados de pressão de preconsolidação têm maiores possibilidades de apresentar condições físicas restritivas para o crescimento das raízes das plantas.

O ambiente físico do solo ao redor das raízes é caracterizado pela aeração, temperatura, umidade e resistência mecânica; sendo que, todas essas propriedades físicas do solo são modificadas, em grau variável, pela compactação do solo (Boon \& Veen, 1994). Gupta \& Allmaras (1987) definiram uma faixa de umidade acima da qual a compactação é prejudicial ao desenvolvimento radicular baseada em três critérios: estresse crítico no qual os agregados sofrem cisalhamento, aeração crítica (10\% da porosidade total) e resistência crítica do solo à penetração radicular. Entretanto, esses autores indicaram a necessidade de delimitar de forma mais precisa valores de estresse crítico para o crescimento das raízes. 
O conceito do "Least Limiting Water Range" (LLWR) foi proposto por Letey (1985) e desenvolvido por Silva et al. (1994) como indicador da qualidade estrutural do solo para o crescimento das raízes visto que integra, num único parâmetro, os três fatores importantes associados ao desenvolvimento das plantas: aeração, umidade e resistência mecânica do solo. Pesquisas têm mostrado que o LLWR, traduzido como Intervalo Hídrico Ótimo (IHO) (Tormena et al., 1998), é alterado pelo grau de compactação do solo (Silva et al., 1994; Silva \& Kay, 1997a; Betz et al., 1998). Entretanto, há carência de estudos que relacionem o indicador de qualidade do solo para o crescimento das plantas (IHO) e o indicador de capacidade de suporte de carga do solo $\left(\sigma_{\mathrm{p}}\right)$. O objetivo deste trabalho foi avaliar o indicador de qualidade estrutural "intervalo hídrico ótimo" e o indicador de trafegabilidade "pressão de preconsolidação", relacionálos e determinar valores de pressões críticas que podem ser aplicados ao solo sem induzir condições restritivas ao crescimento das plantas e sem induzir compactação adicional do solo.

\subsection{Material e Métodos}

Este estudo foi conduzido em um solo classificado como Argissolo Vermelho Amarelo cultivado com cana de açúcar, localizado no município de Piracicaba (SP). O horizonte superficial deste solo possui $730 \mathrm{~g} \mathrm{~kg}^{-1}$ de areia, $80 \mathrm{~g} \mathrm{~kg}^{-1}$ de silte e $190 \mathrm{~g} \mathrm{~kg}^{-1}$ de argila.

No local foram escolhidos 18 pontos de amostragem, aleatoriamente e entre as linhas de cana, de onde foram coletadas 3 amostras (uma amostra deformada e duas indeformadas), totalizando 18 amostras com estrutura deformada e 36 amostras com estrutura indeformada. As amostras foram retiradas no centro da camada superficial do solo $(0,0-0,10 \mathrm{~m})$. Do total de amostras indeformadas, 18 foram coletadas empregando anéis volumétricos de 25,4 $\mathrm{mm}$ de altura por $64 \mathrm{~mm}$ de diâmetro, e as outras 18 amostras indeformadas foram retiradas utilizando anéis volumétricos de $50 \mathrm{~mm}$ de altura por $50 \mathrm{~mm}$ de diâmetro. 
Nas amostras deformadas determinoutse a granulometria (Gee \& Bauder, 1986) e a densidade das partículas (Dp) (Blake \& Hartge,1986). Com o objetivo de simular um gradiente de umidade, as amostras com estrutura indeformada foram saturadas com água por 24 horas e separadas em 6 grupos de 3 amostras, sendo cada grupo submetido a um dos seguintes potenciais mátricos $(\psi)$ : $-0,005,-0,01,-0,03,-0,07$, -0,1 e -1,5 MPa, em mesa de tensão e em panelas de pressão de Richards conforme Klute (1986).

Após atingir o equilíbrio nos referidos potenciais, as amostras de $25,4 \mathrm{~mm}$ de altura por $64 \mathrm{~mm}$ de diâmetro foram submetidas ao ensaio de compressão uniaxial (Dias Junior, 1994). Para a realização do ensaio utilizou-se um consolidômetro da marca Boart Longyear. As pressões $(25,50,100,200,400,800$ e $1600 \mathrm{kPa})$ foram aplicadas por meio de ar comprimido até obter 90\% da deformação máxima (Taylor, 1948). As amostras foram submetidas à aplicação de pressões sucessivas, sem efetuar o descarregamento das pressões previamente aplicadas (Larson \& Gupta, 1980; Kondo \& Dias Junior, 1998). Após a liberação da pressão, as amostras foram secas em estufa a $105-110^{\circ} \mathrm{C}$ por 24 horas e foi determinada a massa seca do solo. A densidade do solo foi calculada a partir dos valores de massa seca do solo previamente medidos e dos valores de volume do solo após a cada carga, os quais foram recalculados a partir das medidas lidas no consolidômetro. Obteve-se a curva de compressão do solo; ou seja, um gráfico com o logaritmo da pressão aplicada no eixo das abscissas versus a densidade do solo no eixo das ordenadas (Dias Junior \& Pierce, 1996). O valor da densidade do solo prévio à aplicação das pressões selecionadas foi denominado densidade inicial do solo $\left(\mathrm{Ds}_{\mathrm{i}}\right)$. $\mathrm{O}$ valor da pressão de preconsolidação $\left(\sigma_{\mathrm{p}}\right)$ foi calculado para cada amostra utilizando a metodologia proposta por Dias Junior \& Pierce (1995).

Após atingir o equilíbrio, nas amostras de $50 \mathrm{~mm}$ de altura por $50 \mathrm{~mm}$ de diâmetro, foi medida a resistência do solo à penetração, utilizando um penetrômetro eletrônico com velocidade constante de penetração de $1 \mathrm{~cm} \mathrm{~min}^{-1}$, e um cone com diâmetro de base de $4 \mathrm{~mm}$ e semi-ângulo de $30^{\circ}$. Esse penetrômetro é equipado com um atuador linear e célula de carga de $20 \mathrm{~kg}$ acoplada a um microcomputador para a aquisição dos dados (Torme na et al., 1998). No centro geométrico de cada amostra e na 
profundidade de 5 a $45 \mathrm{~mm}$, uma leitura de resistência foi obtida a cada $0,1 \mathrm{~mm}$, perfazendo um total de 400 leituras, as quais foram utilizadas para calcular a média da resistência do solo à penetr ação de cada amostra. Após a determinação da resistência à penetração, as amostras foram secas em estufa a $105-110^{\circ} \mathrm{C}$ por 24 horas e determinada a densidade do solo de acordo com Blake \& Hartge (1986).

Os valores de umidade volumétrica $(\theta)$ e do potencial matricial $(\psi)$ foram ajustados utilizando a função empregada por Ross et al. (1991):

$$
\theta=\mathrm{a} * \psi^{\mathrm{b}}
$$

onde $\theta$ é a umidade volumétrica do solo $\left(\mathrm{m}^{3} \mathrm{~m}^{-3}\right), \psi$ é o potencial mátrico (MPa), e $a$ e $b$ são os parâmetros ajustados.

Os dados de resistência à penetr ação $(\mathrm{RP})$ foram ajustados em relação à umidade volumétrica $(\theta)$ e a densidade do solo (Ds) utilizando o modelo não linear proposto por Busscher (1990):

$$
\mathrm{RP}=\mathrm{a} * \theta^{\mathrm{b}} * \mathrm{Ds}{ }^{\mathrm{c}}
$$

ou alternativamente:

$$
\ln \mathrm{RP}=\ln \mathrm{a}+\mathrm{b} * \ln \theta+\mathrm{c} * \ln \mathrm{Ds}
$$

$\mathrm{Na}$ equação (3) RP é a resistência à penetração (MPa), $\theta$ é a umidade volumétrica $\left(\mathrm{m}^{3} \mathrm{~m}^{-3}\right)$, Ds é a densidade do solo $\left(\mathrm{Mg} \mathrm{m}^{-3}\right)$. Os coeficiente $a, b$ e $c$ são os coeficientes do modelo ajustados.

O Intervalo Hídrico Ótimo (IHO) foi calculado para cada Ds medida, seguindo a metodologia proposta por Silva et al. (1994). Para o calculo do IHO, valores críticos de umidade na capacidade de campo $\left(\theta_{\mathrm{CC}}\right)$ (Haise et al., 1955), ponto de murcha permanente $\left(\theta_{\mathrm{PMP}}\right)\left(\right.$ Richards \& Weaver, 1944), porosidade de aeração igual a $10 \%\left(\theta_{\mathrm{PA}}\right)$ (Grable \& Siemer, 1968) e resistência do solo à penetração igual a $2 \mathrm{MPa}\left(\theta_{\mathrm{RP}}\right)$ (Taylor et al., 1966) foram determinados, para cada valor de densidade medida. Os valores de $\theta_{\mathrm{CC}}$ e $\theta_{\mathrm{PMP}}$ foram obtidos utilizando a equação 1 , enquanto que a $\theta_{\mathrm{RP}}$ foi calculada a partir do modelo ajustado de RP. O conteúdo de água que corresponde a uma porosidade de aeração de $10 \%\left(\theta_{\mathrm{PA}}\right)$ foi determinado como $\theta_{\mathrm{PA}}=\theta_{\mathrm{sat}}-0,1$, sendo o conteúdo de água na saturação $\left(\theta_{\text {sat }}\right)$ calculado a partir da Ds e da densidade de partícula (Dp). 
As análises estatísticas foram realizadas utilizando-se técnicas de regressão linear e não linear por meio do programa estatístico SAS (Statistical Analysis System Institute, 1991).

\subsection{Resultados e Discussão}

A regressão linear entre $\sigma_{p}$ e $\theta$ indicou que a $\sigma_{p}$ decresce significativamente com o aumento da umidade do solo, conforme o modelo abaixo (Equação 4).

$$
\sigma_{\mathrm{p}}=755,39-2303,6 \theta \quad\left(\mathrm{R}^{2}=0,81 ; \mathrm{n}=18\right)
$$

A umidade do solo explicou $81 \%$ da variabilidade dos dados ( $\mathrm{F}=68,37$; $\mathrm{p}<0,001)$, demonstrando a influência dessa variável na capacidade de suporte de carga dos solos. A diminuição da $\sigma_{\mathrm{p}}$ com o aumento da umidade do solo foi observado por vários autores, embora alguns deles determinaram uma dependência linear (Reinert, 1990; Veenhof \& McBride, 1996) e outros uma relação exponencial (Dias Junior, 1994; Kondo \& Dias Junior, 1999a).

A regressão linear múltipla, usando o procedimento "stepwise" (Statistical Analysis System Institute, 1991), demonstrou que a densidade inicial do solo $\left(\mathrm{Ds}_{\mathrm{i}}\right)$ foi uma outra propriedade do solo que influenciou a $\sigma_{\mathrm{p}}$. A incorporação dessa variável no modelo elevou significativamente o $\mathrm{R}^{2}$ para o valor de 0,92 ( $\left.\mathrm{F}=90,43 ; \mathrm{p}<0,0001\right)$, conforme indicado na equação 5.

$$
\sigma_{\mathrm{p}}=307,11-2502,59 \theta+296,48 \mathrm{Ds}_{\mathrm{i}}
$$

Os coeficientes do modelo para as variáveis $\theta$ e $\mathrm{Ds}_{\mathrm{i}}$ foram altamente significativos $\left(\theta: \mathrm{p}<0,0001, \mathrm{Ds}_{\mathrm{i}}: \mathrm{p}<0,0003\right)$. A equação 5 indica que a $\sigma_{\mathrm{p}}$ é relacionada negativamente com a umidade do solo e positivamente com a densidade inicial do solo.

A Figura 1 mostra a variação da $\sigma_{p}$ com os valores de $D s_{i}$ e de $\theta$. O solo possui uma baixa capacidade de suporte de carga quando úmido, enquanto a resistência a deformação aumenta com o secamento do solo.

Solos com textura grossa, como o estudado, podem ser mais facilmente deformados quando úmidos em razão do filme de água ao redor das partículas de areia 
atuar como lubrificante, facilitando o rearranjamento das partículas do solo. Com o secamento, ocorre um aumento na capacidade de suporte de carga desses solos, devido à dificuldade de deformar os grãos de areia, constituídos basicamente de quartzo (Larson et al., 1980).

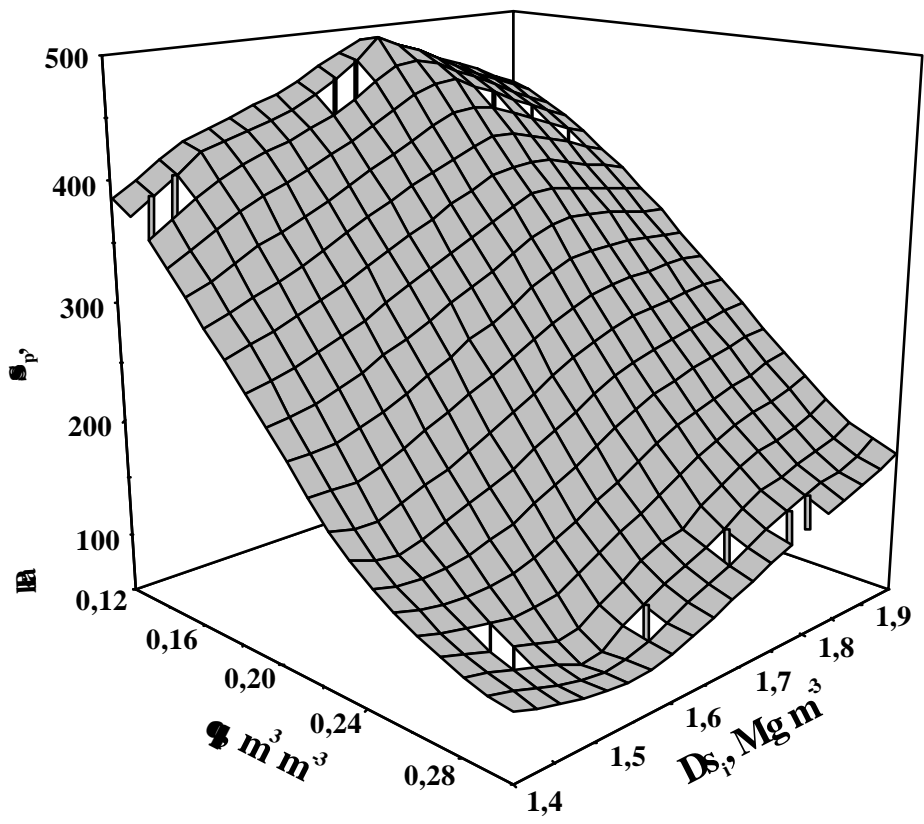

Figura 1 - Variação dos valores da pressão de preconsolidação $\left(\sigma_{\mathrm{p}}\right)$ com a umidade volumétrica $(\theta)$ e a densidade inicial do solo $\left(\mathrm{Ds}_{\mathrm{i}}\right)$.

A dependência da $\sigma_{\mathrm{p}}$ da densidade inicial do solo foi mencionada por vários autores (Reinert, 1990; Veenhof \& McBride, 1996; Kondo \& Dias Junior, 1999b; Silva et al., 2000). O incremento na $\mathrm{Ds}_{\mathrm{i}}$ implica em aumento das forças de fricção e dos pontos de contato entre as partículas e, consequentemente, em menor capacidade de movimentação das mesmas. Nessas condições, a maior dificuldade de deformação do solo induz aumento da capacidade de suporte de carga do solo (Guérif, 1994).

A densidade do solo (Ds) tem sido utilizada como indicador do estado de compactação dos solos (Campbell, 1994), apesar de refletir tanto o efeito das práticas de manejo quanto características do solo, tais como a textura (Silva et al., 1997). O valor de Ds associado com condições estruturais do solo restritivas para o crescimento radicular 
foi definido por Silva et al. (1994) como densidade do solo crítica (Dsc), correspondendo ao valor de Ds em que o IHO é igual a zero.

Como mostrado na Figura 1 , a $\sigma_{\mathrm{p}}$ varia amplamente com a umidade e $\mathrm{Ds}_{\mathrm{i}}$. Decorrente disso é necessário escolher um valor de $\mathrm{Ds}_{\mathrm{i}}$ para a determinação de valores de $\sigma_{\mathrm{p}}$, sendo desejável que esse valor seja indicativo de condições restritivas ao desenvolvimento das plantas. A utilização do valor de Dsc no calculo da $\sigma_{\mathrm{p}}$ permitirá definir a capacidade de suporte de carga do solo levando em consideração a qualidade estrutural do solo para o crescimento das plantas. Para determinar a Dsc, as relações entre os valores de umidade correspondentes à capacidade de campo $\left(\theta_{\mathrm{CC}}\right)$, ao ponto de murcha permanente $\left.\theta_{\mathrm{PMP}}\right)$, à porosidade de aeração $\left(\theta_{\mathrm{PA}}\right)$, à resistência do solo à penetração $\left(\theta_{\mathrm{RP}}\right)$ e $\mathrm{Ds}_{\mathrm{i}}$ foram avaliadas. Os valores de umidade considerados limites do IHO $\left(\theta_{\mathrm{CC}}, \theta_{\mathrm{PMP}}, \theta_{\mathrm{RP}}, \theta_{\mathrm{PA}}\right)$, o IHO e a Dsc são mostrados na Figura 2.

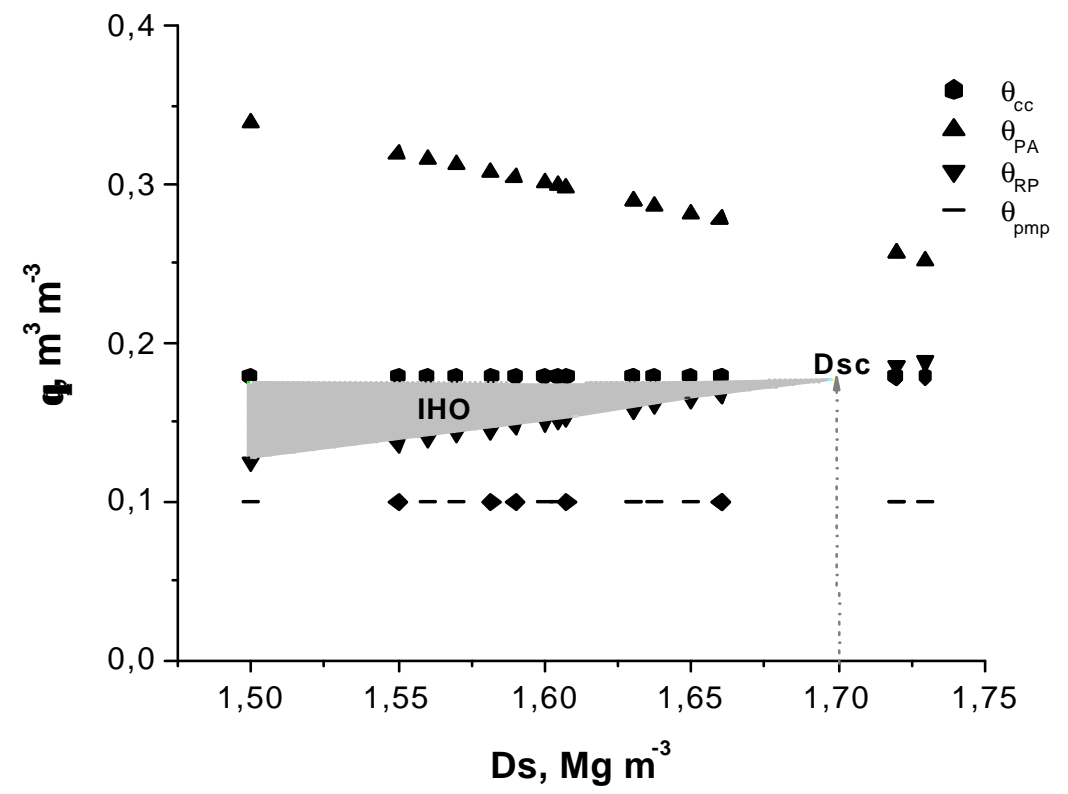

Figura 2 - Variação da umidade volumétrica $(\theta)$ com a densidade inicial do solo $\left(\mathrm{Ds}_{\mathrm{i}}\right)$, para os limites críticos de capacidade de campo $\left(\theta_{\mathrm{cc}}\right)$, ponto de murcha $\left(\theta_{\mathrm{PMP}}\right)$, porosidade de aeração $\left(\theta_{\mathrm{PA}}\right)$ e resistência do solo a penetração $\left(\theta_{\mathrm{RP}}\right)$. IHO = intervalo hídrico ótimo. 
A resistência do solo à pene tração foi afetada pela $\mathrm{Ds}_{\mathrm{i}}$ e umidade do solo (Silva et al., 1994, Tormena et al., 1998). A Ds $s_{i}$ apresentou um coeficiente de variação (CV=4\%) próximo ao determinado por Silva et al. (1997) e Tormena et al. (1998).

Os valores de umidade do solo foram significativamente relacionados com o potencial mátrico $\left(\mathrm{F}=110,80, \mathrm{p}<0,0001, \mathrm{R}^{2}=0,91\right)$; entretanto, a densidade inicial do solo não influenciou o ajuste dos dados no modelo utilizado. Os coeficientes para o modelo ajustado (Ross et al., 1991) são apresentados na equação 6.

$$
\theta=0,305 * \psi^{-0,116}
$$

A equação 6 foi utilizada para estimar a umidade volumétrica do solo nos potenciais de $-0,01 \mathrm{MPa}\left(\theta_{\mathrm{CC}}\right)$ e $-1,5 \mathrm{MPa}\left(\theta_{\mathrm{PMP}}\right)$, dados necessários para a determinação do IHO.

O modelo da curva de $\mathrm{RP}\left(\mathrm{F}=48,13, \mathrm{p}<0,0001, \mathrm{R}^{2}=0,85\right)$ expresso em função das propriedades do solo e segundo a equação (2), é o seguinte:

$$
\mathrm{RP}=0,0002 * \theta^{-2,82} * \mathrm{Ds}_{\mathrm{i}}{ }^{8,21}
$$

Os coeficientes do modelo mostram que a RP é negativamente relacionada à umidade do solo $(\mathrm{p}<0,0001)$ e positivamente relacionada à $\operatorname{Ds}_{\mathrm{i}}(\mathrm{p}<0,0002)$. Esse comportamento da resistência do solo é mencionado por vários autores, para solos e sistemas de manejo diferentes (Busscher et al., 1997; Silva et al., 1994; Tormena et al., 1998).

A umidade em que a RP atingiu o valor de $2 \mathrm{MPa}$, considerado limitante para o desenvolvimento radicular (Taylor et al. 1966; Weaich et al., 1992; Silva et al. 1994), foi determinado rearranjando a equação (7) e inserindo a valor de $2 \mathrm{MPa}$ para RP.

A variação da Dsi não influenciou a retenção de água pelo solo, nos potenciais correspondentes a capacidade de campo $\left(\theta_{\mathrm{CC}}\right)$ e ponto de murcha permanente $\left(\theta_{\mathrm{PMP}}\right)$. Decorrente disso, não houve modificação da água disponível no solo $\left(\theta_{\mathrm{CC}}-\theta_{\mathrm{PMP}}\right)$ com o aumento da Ds. Comportamento similar foi encontrado por Silva et al. (1994) num solo de textura arenosa. 
A $\theta_{\mathrm{PA}}$ foi reduzida com o aumento da $\mathrm{Ds}_{\mathrm{i}}$. No entanto, a falta de oxigênio (porosidade menor que 10\%) não mostrou-se teoricamente restritiva ao crescimento radicular neste solo, visto que o limite de $\theta_{\mathrm{PA}}$ ocorreu sempre em valores de umidade maiores que $\theta_{\mathrm{CC}}$, o que possivelmente pode ser atribuído a textura do solo.

Verificou-se que com o aumento da $\mathrm{Ds}_{\mathrm{i}}$, o valor restritivo de resistência do solo $(\mathrm{RP}=2 \mathrm{MPa})$ foi atingido com umidades no solo sucessivamente maiores. Estes resultados concordam com os obtidos por Silva et al. (1994), Betz et al. (1998) e Tormena et al. (1998). Esses autores observaram que a resistência do solo é o limite crítico que com maior frequiência reduz o IHO, sob condições de secamento do solo. A $\theta_{\mathrm{RP}}$ foi o limite crítico inferior do $\mathrm{IHO}$, superando à $\theta_{\mathrm{PMP}}$ em toda faixa de densidades obtidas neste estudo, indicando redução da qualidade estrutural do solo. Estes resultados refletem, possivelmente, os efeitos do sistema intensivo de cultivo da gleba origem das amostras.

O IHO foi definido, em todo o intervalo de $\mathrm{Ds}_{\mathrm{i}}$ medidas, pela $\theta_{\mathrm{CC}}$ (limite superior) e $\theta_{\mathrm{RP}}$ (limite inferior) (Figura 2). Quanto menor a magnitude do IHO, maior o risco de expor as culturas a condições físicas do solo inadequadas por falta ou excesso de água (Silva \& Kay, 1997b). O IHO diminuiu com o aumento da densidade inicial do solo e pode ser considerado reduzido (IHO variou entre $0 \mathrm{~m}^{3} \mathrm{~m}^{-3}$ e $0,0545 \mathrm{~m}^{3} \mathrm{~m}^{-3}$ ) quando comparado aos valores obtidos por Silva et al. (1994) para um solo canadense de textura semelhante ao estudado (IHO variou entre $0,0537 \mathrm{~m}^{3} \mathrm{~m}^{-3} \mathrm{e} 0,1326 \mathrm{~m}^{3} \mathrm{~m}^{-3}$ ).

O IHO demostrou ser um indicador mais sensível que a água disponível para detectar alterações na qualidade física do solo com o incremento nos valores de $\mathrm{Ds}_{\mathrm{i}}$, concordando com os resultados de Silva et al. (1994), Betz et al. (1998) e Tormena et al. (1998).

$\mathrm{O}$ valor de $\mathrm{Ds}_{\mathrm{i}}$ em que ocorre a interseção das linhas relativas ao limite superior $\left(\theta_{\mathrm{CC}}\right)$ e inferior $\left(\theta_{\mathrm{RP}}\right), \mathrm{IHO}=0$, é denominado densidade do solo crítica (Dsc), que foi determinado como sendo igual a $1,70 \mathrm{Mg} \mathrm{m}^{-3}$. Valores de $\mathrm{Ds}_{\mathrm{i}}$ maiores que esse valor implicam em condições altamente restritivas ao crescimento radicular. Esse valor foi utilizado na equação 5 para estimar a capacidade de suporte de carga do solo. 
Visto que a $\sigma_{\mathrm{p}}$ também varia com a umidade do solo, foi necessário definir valores de umidade de maior interesse. A faixa de umidade que incorpora as limitações para o crescimento das plantas relacionadas com a aeração, água disponível e resistência do solo à penetração ( $\theta$ variando entre $0,34 \mathrm{~m}^{3} \mathrm{~m}^{-3}$ e $0,10 \mathrm{~m}^{3} \mathrm{~m}^{-3}$, Figura 2$)$ foi escolhida para a realização dos cálculos. Os valores de $\sigma_{\mathrm{p}}$ para essa faixa de umidade e para Dsc=1,70 $\mathrm{Mg} \mathrm{m}^{-3}$, estimados por meio da equação 5, são apresentados na Figura 3.

A capacidade de suporte de carga do solo decresce rapidamente com o aumento da umidade no solo, variando entre $578 \mathrm{kPa}$ e $0 \mathrm{kPa}$, para os valores de umidade que correspondem ao ponto de murcha permanente e a $10 \%$ de aeração, respectivamente.

Considerando, na Figura 3, a faixa de umidade que corresponde à máxima amplitude do IHO ( $\theta$ entre $0,18 \mathrm{~m}^{3} \mathrm{~m}^{-3}$ e $\left.0,12 \mathrm{~m}^{3} \mathrm{~m}^{-3}\right)$ identifica-se uma faixa de valores de $\sigma_{\mathrm{p}}$, os quais representam pressões críticas para as plantas (Pcr).

A pressão crítica para o crescimento das plantas (Pcr) é definida, neste trabalho, como a pressão máxima que poderá ser aplicada ao solo sem induzir condições restritivas ao crescimento radicular (valores de $\mathrm{Ds}_{\mathrm{i}}$ maiores que Dsc) e sem promover deformação adicional do solo (valores de pressões maiores que $\sigma_{\mathrm{p}}$ ).

O intervalo de Pcr assim delimitado (máxima amplitude do IHO) varia, aproximadamente, entre $360 \mathrm{kPa}$ e $500 \mathrm{kPa}$ (Figura 3), os quais representam as pressões máximas que poderão ser aplicados ao solo, sem induzir a sua degradação estrutural naquele intervalo de umidade (Dias Junior et al., 1999). Estas pressões são consideradas elevadas tendo em vista a pressão aplicada ao solo pelos equipamentos motomecanizados tradicionais. Hakansson et al. (1988) já assinalavam valores de pressões aplicadas ao solo que variavam de 100 a $150 \mathrm{kPa}$ para tratores e de 200 a 300 kPa para colheitadeiras. A elevada capacidade de suporte de carga do solo determinada neste estudo pode ser atribuída à textura e ao grau de compactação pretérita do mesmo.

Na Figura 3 se observa que os valores de umidade maiores que $0,18 \mathrm{~m}^{3} \mathrm{~m}^{-3}$ (capacidade de campo para o solo estudado) implicam em redução da capacidade de suporte de carga do solo. Para valores de umidade maiores que $0,18 \mathrm{~m} \mathrm{~m}^{-3}$, a aplicação 
de pressões superiores a $360 \mathrm{kPa}$ conduziram a compactação adicional do solo e a condições restritivas ao desenvolvimento radicular $\left(\theta_{\mathrm{CC}}=\right.$ limite superior do IHO, Figura 2).

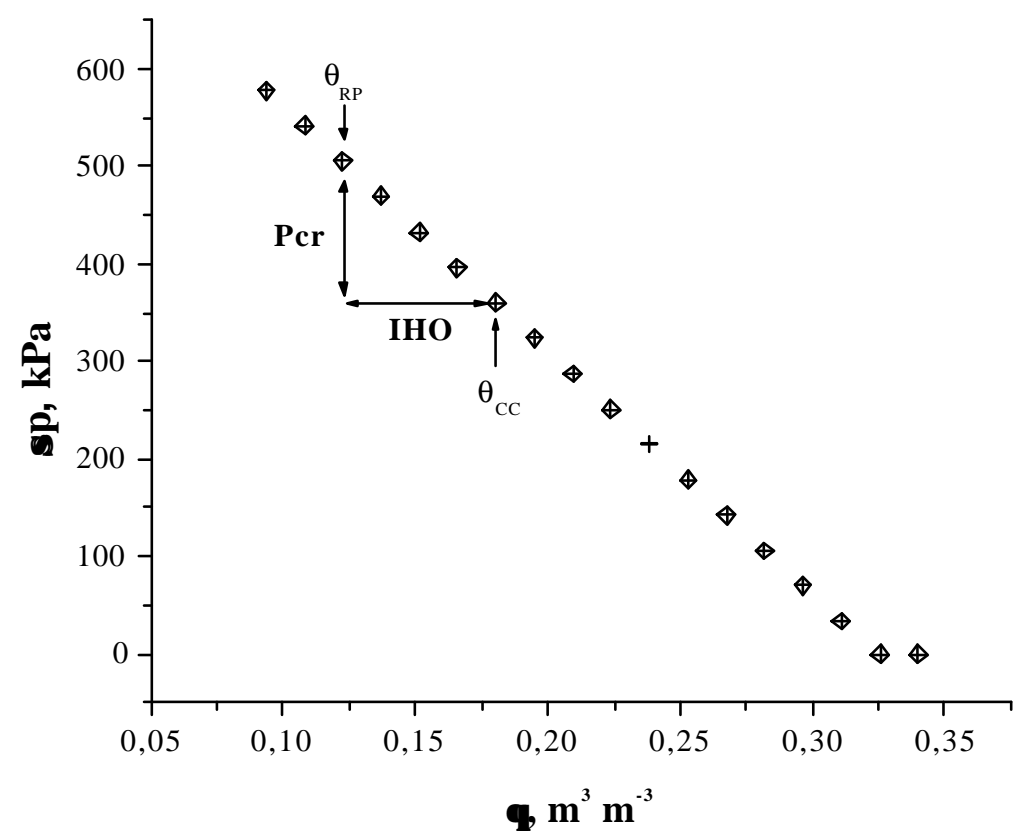

Figura 3 - Variação da capacidade de suporte de carga do solo $\left(\sigma_{\mathrm{p}}\right)$ com a umidade volumétrica $(\theta)$, para um valor de densidade do solo crítica igual a $1,70 \mathrm{Mg}$ $\mathrm{m}^{-3}$.

Como indicado pela equação 5, os valores de Pcr são função da umidade e do valor de Dsc. A Dsc pode variar em função do valor de RP selecionado para a determinação do IHO. Pesquisas têm mostrado que, dependendo da espécie, as plantas diferem na sua capacidade de resposta a condições restritivas no ambiente radicular (Materechera et al., 1991). O IHO foi recalculado para valores de $\mathrm{RP}=1 \mathrm{MPa}$ e $\mathrm{RP}=3 \mathrm{MPa}$, os quais também têm sido mencionados na literatura como valores de $\mathrm{RP}$ críticos (Bengough \& Mullins, 1990). Os valores de Dsc obtidos foram Dsc $=1,56 \mathrm{Mg}$ $\mathrm{m}^{-3}$ para $\mathrm{RP}=1 \mathrm{MPa}$, e $\mathrm{Dsc}=1,78 \mathrm{Mg} \mathrm{m}^{-3}$ para $\mathrm{RP}=3 \mathrm{MPa}$. Os intervalos de Pcr recalculados foram de 316 a $461 \mathrm{kPa}$ para $\mathrm{Dsc}=1,56 \mathrm{Mg} \mathrm{m}^{-3}$, e de 386 a $531 \mathrm{kPa}$ para e Dsc=1,78 $\mathrm{Mg} \mathrm{m}^{-3}$. A capacidade de suporte do solo continua sendo elevada, embora o 
valor de Pcr=316 $\mathrm{kPa}$ possa ser mais facilmente superado por equipamentos motomecanizados modernos. Os resultados sugerem que cuidados adicionais serão necessários para evitar a compactação adicional do solo no caso de culturas sensíveis mais sensíveis a RP.

A quantificação de Pcr, como proposto, permite definir a pressão máxima que pode ser aplicada ao solo para diferentes umidades e valores de Dsc, auxiliando na seleção de sistemas de manejo sustentáveis. Neste contexto, a Pcr pode ser útil na escolha de equipamentos agrícolas, bem como na definição do momento mais oportuno para a realização das atividades de preparo do solo e/ou tráfego da maquinaria agrícola, principalmente em áreas irrigadas mecanizadas, nas quais a umidade é mantida dentro da faixa menos limitante determinada pelo IHO.

O valor de Pcr pode vir a ser um indicador útil para prevenir a degradação da qualidade física dos solos, visto que reúne a informação oferecida pelo indicador de qualidade estrutural do solo para o crescimento das plantas (IHO) e o indicador de trafegabilidade dos solos $\left(\sigma_{\mathrm{p}}\right)$. Mais pesquisas são requeridas nessa área de estudo para diferentes condições de clima, manejo e solos.

\subsection{Conclusões}

1. A informação do IHO e da $\sigma_{\mathrm{p}}$ reunidas permite definir um novo indicador, a pressão crítica para o crescimento das plantas.

2. A Pcr é um indicador da pressão máxima que pode ser aplicada sem promover deterioração da qualidade física do solo para o crescimento das plantas. 


\section{CONCLUSÕES GERAIS}

Neste estudo confirmourse a hipótese de que indicadores de qualidade física da cama de semeadura e da capacidade de suporte para o tráfego de Latossolos e Argissolos Vermelhos podem ser estimados a partir de atributos do solo facilmente mensuráveis.

Os indicadores da condição estrutural após o preparo do solo; a saber, a resistência tênsil e a friabilidade, foram afetados pelas características do solo, especificamente pelo teor de argila, silte, matéria orgânica e óxidos de Fe, Al e Si.

Os indicadores de trafegabilidade; a saber, a susceptibilidade à compactação, a pressão de preconsolidação e a compressibilidade, foram influenciados pelas características do solo, notadamente pelo teor de argila, e pelas propriedades físicas, especificamente pela densidade do solo e a umidade.

O indicador de qualidade estrutural para o crescimento das plantas; a saber, o intervalo hídrico ótimo, foi dependente da umidade e da densidade do solo.

Um novo indicador de qualidade estrutural do solo, denominado "pressão crítica para o crescimento das plantas", foi proposto para prevenir a degradação da qualidade física dos solos agrícolas.

Funções de pedotransferência, que podem ser utilizadas como base para a tomada de decisão na escolha do tipo de máquina agrícola (capacidade de carga, pressão de inflação de ar dos pneus) mais adequada a cada situação, bem como na definição do momento mais oportuno para a realização das atividades de preparo do solo e/ou tráfego de máquinas agrícolas nas áreas estudadas, foram geradas.

Pesquisas complementares serão necessárias para validar as funções de pedotransferência elaboradas, a fim de que as mesmas possam ser utilizadas em outras áreas de características semelhantes. 


\section{REFERÊNCIAS BIBLIOGRÁFICAS}

AIKEN, L.S.; WEST, S.G. Multiple regression: testing and interpreting interactions. Newbury Park: SAGE Publ., 1991. 211p.

ALEXANDROU, A.; EARL, R. The relationship among the pre-compaction stress, volumetric water content and initial dry bulk density of soil. Journal of Agricultural Engineering Research, v.71, n.1, p.75-80, 1998.

ANJOS, L.H.; FERNANDES, M.R.; PEREIRA, M.G.; FRANZMEIER, D.P. Landscape and pedogenesis of an Oxisol-Inceptisol-Ultisol sequence in southeastern Brazil. Soil Science Society of America Journal, v.62, n.6, p.1651-1658, 1998.

ASSOULINE, S.; TAVARES, J.; TESSIER, D. Effect of compaction on soil physical and hydraulic properties: experimental results and modeling. Soil Science Society of America Journal, v.61, n.2, p.390-398, 1997.

BAILEY, A.C.; JOHNSON, C.E.; SCHAFER, R.L. A model for agricultural soil compaction. Journal of Agricultural Engineering Research, v.33, n.4, p.257$262,1986$.

BARRAL, M.T.; ARIAS, M.; GUÉRIF, J. Effects of iron and organic matter on the porosity and structural stability of soil aggregates. Soil Tillage Research, v.46, n.34, p.261-272, 1998.

BARTOLI, F.; BURTIN, G.; GUÉRIF, J. Influence of organic matter on aggregation in Oxisols rich in gibbsite or in goethite. II. Clay dispersion, aggregate strength and water stability. Geoderma, v. 54, n.1/4, p.259-274, 1992a.

BARTOLI, F.; PHILIPPY, R.; BURTIN, G. Poorly-ordered hydrous Fe oxides, colloidal dispersion associated or not with humic macromolecule models. Journal of Soil Science, v.43, n.1, p.47-58, 1992b. 
BARZEGAR, A.R.; MURRAY, R.S.; CHURCHMAN, G.J.; RENGASAMY, P. The strength of remolded soils as affected by exchangeable cations and dispersible clay. Australian Journal of Soil Research, v.32, n.2, p.185-199, 1994.

BENGHOUGH, A.G.; MULLINS, C.E. Mechanical impedance to root growth: a review of experimental techniques and root growth responses. Journal of Soil Science, v.41, n.1, p.341-358, 1990.

BETZ, C.L.; ALLMARAS, R.R.; COPELAND, S.M.; RANDALL, G.W. Least limitng water range: traffic and long-term tillage influences in a Webster soil. Soil Science Society of America Journal, v.62, n.5, p.1384-1393, 1998.

BLAKE, G.R.; HARTGE, K.H. Bulk density. In: KLUTE, A. (Ed.) Methods of soil analysis: physical and mineralogical methods. 2.ed. Madison: American Society of Agronomy, 1986. v.1, p.363-375.

BLAKE, G.R.; HARTGE, K.H. Particle density. In: KLUTE, A. (Ed.) Methods of soil analysis: physical and mineralogical methods. 2.ed. Madison: American Society of Agronomy, 1986. v.1, p.377-382.

BOONE, F.R.; VEEN, B.W. Mechanisms of crop responses to soil compaction. In: SOANE, B.D.; VAN OUWERKERK, C. (Ed.) Soil compaction in crop production. Amsterdam: Elsevier, 1994. cap.11, p.237-264.

BOUMA, J. Using soil survey data for quantitative land evaluation. Advances in Soil Science, v.9, p.177-213, 1989.

BRADFORD, J.M.; GUPTA, S.C. Compressibility. In: KLUTE, A. (Ed.) Methods of soil analysis: physical and mineralogical methods. 2.ed. Madison: American Society of Agronomy, 1986. cap.19, p.463-660.

BURGER, J.A.; KELTING, DL. Using soil quality indicators to assess forest stand management. Forest Ecology and Management, v.122, n.1/2, p.155-166, 1999.

BUSSCHER, W.J. Adjustment of flat-tipped penetrometer resistance data to a common water content. Transactions of the ASAE, v.33, n.2, p.519-524, 1990.

BUSSCHER, W.J.; BAUER, P.J.; CAMP, C.R.; SOJKA, R.E. Correction of cone index for soil water content differences in a coastal plain soil. Soil and Tillage Research, v.43, n.3/4, p.205-217, 1997. 
CAMPBELL, D.J. Determination and use of soil bulk density in relation to soil compaction. In: SOANE, B.D.; VAN OUWERKERK, C. (Ed.) Soil compaction in crop production. Amsterdam: Elsevier, 1994. cap.6, p.113-139.

CANARACHE, A.; HORN, R.; COLIBAS, I. Compressibility of soils in a long term field experiment with intensive deep ripping in Romania. Soil and Tillage Research, v.56, n.3-4, p.185-196, 2000.

CARTER, M.R.; GREGORICH, E.G.; ANDERSON, D.W.; DORAN, J.W.; JANZEN, H.H.; PIERCE, F.J. Concepts of soil quality and their significance. In: GREGORICH, E.G.; CARTER, M.R. (Ed.) Soil quality for crop production and ecosystem health. Amsterdam: Elsevier Science, 1997. p.1-19.

CASAGRANDE, A. The determination of the precompression stress and its practical significance. In: INTERNATIONAL CONFERENCE ON SOIL MECHANIC AND FOUNDATION ENGINEERING, 3., Cambridge, 1936. Proceedings. Cambridge: MA Harvard University, 1936. p.60-64.

CAUSARANO, H. Factors affecting the tensile strength of soil aggregates. Soil and Tillage Research, v.28, n.1, p.15-25, 1993.

CHAN, K.Y.; DEXTER, A.R.; MCKENZIE, D.C. Categories of soil structure based on mechanical behaviour and their evaluation using additions of lime and gypsum on a sodic Vertisol. Australian Journal of Soil Research, v.37, n.5, p.903-911, 1999.

CULLEY, J.L.B.; LARSON, W.E. Susceptibility to compression of a Clay Loam Haplaquoll. Soil Science Society of America Journal, v.51, n.3, p.562-567, 1987.

DESPHANDE, T.L.; GREENLAND, D.J.; QUIRK, J.P. Charges in soil properties associated with the removal of iron and aluminum oxides. Journal of Soil Science, v.19, n.1, p.108-122, 1968.

DEXTER, A.R.; KROESBERGEN, B. Methodology for determination of tensile strength of soil aggregates. Journal of Agricultural Engineering Research, v.31, n.2, p.139-147, 1985.

DEXTER, A.R. Advances in characterization of soil structure. Soil and Tillage Research, v.11, n.3/4, p.199-238, 1988a. 
DEXTER, A.R. Strength of soil aggregates and of aggregate beds. Catena, suppl. 11, p.35-52, $1988 b$.

DEXTER, A.R.; WATTS, C. Tensile strength and friability. In: SMITH, K.; MULLINS, C. (Ed.) Soil and environmental analysis, physical methods. 2. ed. New York: Marcel Dekker, 2000. p. 401-430.

DIAS JUNIOR, M.S. Compression of three soils under long-term tillage wheel traffic. East Lansing, 1994. 114 p. Thesis (Ph.D) - Michigan State University.

DIAS JUNIOR, M.S.; PIERCE, F.J. A simple procedure for estimating preconsolidation pressure from soil compression curves. Soil Technology, v.8, n.2, p.139-151, 1995.

DIAS JUNIOR, M.S.; PIERCE, F.J. O processo de compactação do solo e sua modelagem. Revista Brasileira de Ciência do Solo, v.20, n.1, p.175-182, 1996.

DIAS JUNIOR, M.S.; FERREIRA, M.M.; FONSECA, S.; SILVA, A.R.; FERREIRA, D.F. Avaliação quantitativa da sustentabilidade estrutural dos solos em sistemas florestais na região de Aracruz-ES. Revista Árvore, v.23, n.4, p371-380, 1999.

DROOGERS, P.; FERMONT, A.; BOUMA, J. Effects of ecological management on workability and trafficability of a loamy soil in the Nethederlans. Geoderma, v.73, p.131-145, 1996.

ETANA, A.; COMIA, R.A.; HAKANSSON, I. Effects of uniaxial stress on the physical properties of four Swedish soils. Soil and Tillage Research, v.44, n.1, p.13-21, 1997.

FAURE, A. A new conception of the plastic and liquid limits of clay. Soil and Tillage Research, v.1, n.2, p.97-105, 1981.

FERREIRA, M.M.; FERNANDES, B.; CURI, N. Influência da mineralogia da fração argila nas propriedades físicas de Latossolos da Região Sudeste do Brasil. Revista Brasileira de Ciência do Solo, v.23, n3, p.515-524, 1999.

GEE, G.W.; BAUDER, J.W. Particle-size analysis. In: KLUTE, A. (Ed.) Methods of soil analysis: physical and mineralogical methods. 2.ed. Madison: American Society of Agronomy, 1986. p.383-411.

GLANTZ, S.A.; SLINKER, B.K. Primer of applied regression and analysis of variance. New York: McGraw-Hill, 1990. 777p. 
GOLDBERG, S.; KAPOOR, B.S.; RHOADES, J.D. Effect of aluminum and iron oxides and organic matter on flocculation and dispersion of arid zone soils. Soil Science, v.150, n.3, p.588-593, 1990.

GRABLE, A.R.; SIEMER, E.G. Effects of bulk density, aggregate size and soil water suction on oxygen diffusion, redox potential and elongation of corn roots. Soil Science Society of America Proceedings, v.32, n.2, p.180-186, 1968.

GRANT, C.D.; DEXTER, A.R.; HUANG, C. Roughness of soil fracture surfaces as a measure of soil microstructure. Journal of Soil Science, v.41, p. 95-110, 1990.

GREGORICH, E.G.; CARTER, M.R.; ANGERS, D.A.; MONREAL, C.M.; DWYER, L.M. Towards a minimum data set to assess soil organic matter quality in agricultural soils. Canadian Journal of Soil Science, v.74, n.4, p.367-386, 1994.

GUÉRIF, J. Factors influencing compaction-induced increases in soil strength. Soil and Tillage Research, v.16, n.2, p.167-178, 1990.

GUÉRIF, J. Effects of compaction on soil strength parameters. In: SOANE, B.D.; VAN OUWERKERK, C. (Ed.) Soil compaction in crop production. Amsterdam: Elsevier, 1994. p.191-214.

GUPTA, S.C.; ALLMARAS, R.R. Models to assess the susceptibility of soils to excessive compaction. Advances in Soil Science, v.6, p.65-100, 1987.

HAISE, H.R.; HAAS, H.J.; JENSEN, L.R. Soil moisture studies of some Great Plain soils: II. Field capacity as related to $1 / 3$-atmosphere percentage and "minimum point" as related to 15- and 26-atmosphere percentages. Soil Science Society of America Proceedings, v.34, n.1, p.20-25, 1955.

HAKANSSON, I. A method for characterizing the state of compactness of the plough layer. Soil and Tillage Research, v.16, n.1-2, p.105-120, 1990.

HAKANSSON, I.; LIEPIC, J. A review of the usefulness of relative bulk density values in studies of soil structure and compaction. Soil and Tillage Research, v.52, n.2, p.71-85, 2000.

HAKANSSON, I.; VOORHEES, W.B.; RILEY, H. Vehicle and wheel factors influencing soil compaction and crop response in different traffic regimes. Soil and Tillage Research, v.11, n.3-4, p.239-282, 1988. 
HAKANSSON, I.; VOORHEES, W.B. Soil compaction. In: LAL, R.; BLUM, W.H.; VALENTINE, C.; STEWARD, B.A. (Ed.) Methods for assessment of soil degradation. Boca Raton: CRS Press, 1998. p.167-179.

HARTE, K.K. The effect of soil deformation on physical soil properties: a discourse on the common background. In: HORN, R.; AKKER van den, J.J.H.; ARVIDSSON, J. (Ed.) Subsoil compaction: distribution, processes and consequences. Reiskirchen: Catena Verlag, 2000. p.22-31. (Advances in GeoEcology, 32)

HORN, R. Compressibility of arable land. Catena, suppl. 11, p.53-71, 1988.

HORN, R.; LEBERT, M. Soil compactability and compressibility. In: SOANE, B.D.; VAN OUWERKERK, C. (Ed.) Soil compaction in crop production. Amsterdam: Elsevier, 1994. p.45-69.

IGWE, C.A.; AKAMIGBO, F.O.R.; MBAGWU, J.S.C. Chemical and mineralogical properties of soils in southeastern Nigeria in relation to aggregate stability. Geoderma, v.92, n.1/2, p.111-123, 1999.

KANALI, C.L.; KAUMBUTHO, P.G.; MAENDE, C.M.; KAMAU, J. The use of soil compaction levels in the selection of field-safe sugarcane transport vehicles. Journal of Terramechanics, v.34, n.2, p.127-140, 1997.

KARLEN, D.L.; EASH, N.S.; UNGER, P.W. Soil and crop management effects on soil quality indicators. American Journal of Alternative Agriculture, v.7, n.1, p.4855. 1992.

KARLEN, D.L.; MAUSBACH, M.J.; DORAN, J.W., CLINE, R.G.; HARRIS, R.F.; SCHUMAN, G.E. Soil quality: a concept, definition and framework for evaluation. Soil Science Society of America Journal, v.61, n.1, p.4-10, 1997.

KAY, B.D. Assessing the suitability of different soils for new ropping systems in terms of rates of change in soil structure. In: LARSON, W.E.; BLAKE, G.R.; ALLMARAS, R.R.; VOORHEES, W.B.; GUPTA, S.C. (Ed.) Mechanics and related processes in structured agricultural soils. Dordrecht: NATO, 1989. cap.17. p.223-232.

KAY, B.D.; ANGERS, D.A. Soil structure. In: SUMNER, M.E. (Ed.) Handbook of soil science. Boca Raton: CRC Press, 1999. p.229-276. 
KAY, B.D., DEXTER, A.R. The influence of dispersible clay and wetting/drying cycles on the tensile strength of a Red-Brown Earth. Australian Journal of Soil Research, v.30, n.3, p.297-310, 1992.

KAY, B.D.; SILVA, A.P. da; BALDOCK, J. A. Sensitivity of soil structure to changes in organic carbon content: Predictions using pedotransfer functions. Canadian Journal of Soil Science, v.77, n.4, p.655-667, 1997.

KAYOMBO, B.; LAL, R. Responses of tropical crops to soil compaction. In: SOANE, B.D.; VAN OUWERKERK, C. (Ed.) Soil compaction in crop production. Amsterdam: Elsevier, 1994. p.287-316.

KEMPER, W.D.; ROSENAU, R.C.; DEXTER, A.R. Cohesion development in disrupted soils as affected by clay and organic matter content and temperature. Soil Science Society of America Journal , v.51, n.4, p.860-867, 1987.

KLUTE, A. Water retention: laboratory methods. In: KLUTE, A. (Ed.) Methods of soil analysis: physical and mineralogical methods. 2.ed. Madison: American Society of Agronomy, 1986. cap.26, p.635-660.

KONDO, M.K. Compressibilidade de três Latossolos sob diferentes usos. Lavras, 1998. 95p. Dissertação (Mestrado)-Universidade Federal de Lavras.

KONDO, M.K.; DIAS JUNIOR, M.S. Efeito do manejo e da umidade no comportamento compressivo de três Latossolos. Revista Brasileira de Ciência do Solo, v.23, n.3, p.497-506, 1999a.

KONDO, M.K.; DIAS JUNIOR, M.S. Estimativa do efe ito do uso e da umidade do solo sobre a compactação adicional de três Latossolos. Revista Brasileira de Ciência do Solo, v.23, n.4, p.773-782, 1999b.

KONDO, M.K.; DIAS JUNIOR, M.S. Compressibilidade de três Latossolos em função da umidade e uso. Revista Brasileira de Ciência do Solo, v.23, n.2, p.211-218, 1999c.

KOOLEN, A.J. Mechanics of soil compaction. In: SOANE, B.D.; VAN OUWERKERK, C. (Ed.) Soil compaction in crop production. Amsterdam: Elsevier, 1994. cap 2, p.23-44. 
LAL, R. Trends in world agricultural use: potential and constraints. In: LAL, R; STEWART, B. (Ed.) Soil magement, experimental basis for sustainability and environmental quality. Boca Raton: CRC Press, 1995. p.521-535.

LARSON, W.E.; GUPTA, S.C. Estimating critical stress in unsaturated soils from changes in pore water pressure during confined compression. Soil Science Society of America Journal, v.44, n.6, p.1127-1132, 1980.

LARSON, W.E.; GUPTA, S.C.; USECHE, R.A. Compression of agricultural soils from eight soil orders. Soil Science Society of America Journal, v.44, n.3, p.450-457, 1980.

LEBERT, M.; HORN, R. A method to predict the mechanical strength of agricultural soils. Soil and Tillage Research, v.19, n.2/3, p.275-286, 1991.

LETEY, J. Relationship between soil physical properties and crop production. Advances in Soil Science, v.1, p.277-294, 1985.

LEY, G.J.; MULLINS, C.E.; LAL, R. Effects of soil properties on the strength of weakly structures tropical soils. Soil and Tillage Research, v.28, n.1, p.1-13, 1993.

MACKS, S.P.; MURPHY, B.W.; CRESSWELL, H.P.; KOEN, T.B. Soil friability in relation to management history and suitability for direct drilling. Australian Journal of Soil Research, v.34, n.3, p.343-360, 1996.

MATERECHERA, S.A.; DEXTER, A.R.; ALSTON, A.M. Penetration of very strong soils by seedling roots of different plant species. Plant and Soil, v.135, n.1, p.3141, 1991.

MCBRIDE, R. A. Estimation of density-moisture-stress functions from uniaxial compression of unsaturated, structured soils. Soil and Tillage Research, v.13, n.4, p.383-397, 1989.

MCBRIDE, R. A.; BOBER, M.L. A re-examination of alternative test procedures for soil consistency limit determination: I. A compression-based procedure. Soil Science Society of America Journal, v.53, n.1, p.178-183, 1989.

MCBRIDE, R. A.; JOOSSE, P.J. Overconsolidation in agricultural soils: II. Pedotransfer functions for estimating preconsolidation stress. Soil Science Society of America Journal, v.60, n.2, p.373-380, 1996. 
MCBRIDE, R. A.; WATSON, G.C. An investigation of re-expansion of unsaturated, structured soils during cyclic static loading. Soil and Tillage Research, v.17, n.3/4, p.241-253, 1990.

MCNABB, D.H.; BOERSMA, L. Evaluation of the relationship between compressibility and shear strength of Andisols. Soil Science Society of America Journal, v.57, n.4, p.923-929, 1993.

MCNABB, D.H.; BOERSMA, L. Nonlinear model for compressibility of partly saturated soils. Soil Science Society of America Journal, v.60, n.2, p.333-341, 1996.

MEHRA, O.P.; JACKSON, M.L. Iron oxide removal from soils and clay by dithionitecitrate-bicarbonate system buffered with sodium bicarbonate. Clay Mineralogy, v.7, p.317-327, 1960.

MUGGLER, C.C.; PAPE, TH.; BUURMAN, P. Laser grain-size determination in soil genetic studies 2. Clay content, clay formation, and aggregation in some Brazilian Oxisols. Soil Science, v.162, n.3, p.219-228, 1997.

MUGGLER, C.C.; VAN GRIETHUYSEN, C.; BUURMAN, P.; PAPE, T. Aggregation, organic matter, and iron oxide morphology in Oxisols from Minas Gerais, Brazil. Soil Science, v.164, n.10, p.759-770, 1999.

NETER, J.; WASSERMAN, W.; KUTNER, M.H. Applied linear regression models. 2.ed. Homewood: R. Irwin. 1989. 245p.

O'SULLIVAN, M.F. Uniaxial compaction effects on soil physical properties in relation to soil type and cultivation. Soil and Tillage Research, v.24, n.3/4, p.257-269, 1992.

PAZ, A.; GUÉRIF, J. Influence of initial packing density, water content and load applied during compaction on tensile strength of dry soil structural units. In: HORN, R.; AKKER van den, J.J.H.; ARVIDSSON, J. (Ed.) Subsoil compaction: distribution, processes and consequences. Reiskirchen: Catena Verlag, 2000. p.2231. (Advances in GeoEcology, 32) 
PERFECT, E.; KAY, B.D.; SILVA A.P. da. Influence of soil properties on the statistical characterization of dry aggregate strength. Soil Science Society of America Journal, v.59, n.2, p.532-537, 1995.

PINHEIRO-DICK, D.; SCHWERTMANN, U. Microaggreggates from Oxisols and Inceptisols: dispersion through selective dissolutions and physicochemical treatments. Geoderma, v.74, n.1/2, p.49-63, 1996.

RAHIMI, H.; PAZIRA, E.; TAJIK, F. Effect of soil organic matter, electrical conductivity and sodium adsorption ratio on tensile strength of aggregates. Soil and Tillage Research, v.54, n.3/4, p.145-153, 2000.

RAIJ, B. van; QUAGGIO, J.A ; CANTARELLA, H.; FERREIRA, M.E.; LOPES, A.S.; BATAGLIA, O.C. Análise química do solo para fins de fertilidade. Campinas: Fundação Cargill, 1987. 170p.

REINERT, D.J. Soil structural form and stability inducted by tillage in a typic Hapludalf. East Lansing, 1990. 128p. Thesis (Ph.D) - Michigan State University.

RICHARDS, L.A.; WEAVER, L.R. Fifteen atmosphere percentage as related to the permanent wilting point. Soil Science, v.56, n.4, p.331-339, 1944.

RÖMKENS, M.K.; MILLER, R.D. Predicting root size and frequency from onedimensional consolidation data- A mathematical model. Plant and Soil, v.35, n.3, p.237-248, 1971.

ROSS, P.J.; WILLIANS, J.; BRISTOW, K.L. Equations for extending water-retention curves to dryness. Soil Science Society of America Journal, v.55, n.5, p.923-927, 1991.

SÁNCHEZ-GUIRÓN, V.; ANDREU, E.; HERNANZ, J.L. Response of five types of soil to simulated compaction in the form of confined uniaxial compression test. Soil and Tillage Research, v.48, n.1/2, p.37-50, 1998.

SCHOENHOLTZ, S.H.; VAN MIEGROET, H.; BURGER, J.A. A review of chemical and physical properties as indicators of forest soil quality: challenges and opportunities. Forest Ecology and Management, v.138, p.335-356, 2000. 
SCHWERTMANN, U. Differenzierung der eisenoxide des bodens durch extraktion mit ammoniumoxalate-losung. Zeitschrift fur Pflanzenernahrung und Bodenkunde, V.105, p.194-202, 1964.

SILVA, A.P. da; KAY, B.D.; PERFECT, E. Characterization of the least limiting water range. Soil Science Society of America Journal, v.58, n.6, p.1775-1781, 1994.

SILVA, A.P. da; KAY, B.D. The sensitivity of shoot growth of corn to the least limiting water range of soils. Plant and Soil, v.184, n.2, p.323-329, 1996.

SILVA, A.P. da; KAY, B.D. Estimating the least limiting water range of soil from properties and management. Soil Science Society of America Journal, v.61, n.3, p.877-883, 1997a.

SILVA, A.P. da; KAY, B.D. Effect of soil water content variation on the least limiting water range. Soil Science Society of America Journal, v.61, n.3, p.884-888, 1997b.

SILVA, A.P. da; KAY, B.D.; PERFECT, E. Management versus inherent soil properties effects on bulk density and relative compaction. Soil and Tillage Research, v.44, n.1/2, p.81-93, 1997.

SILVA, V.R.; REINERT, D.J.; REICHERT, J.M. Susceptibilidade à compactação de um Latossolo Vermelho-Escuro e de um Podzólico Vermelho-Amarelo. Revista Brasileira de Ciência do Solo, v.24, n.2, p.239-250, 2000.

SILVA, V.R.; REINERT, D.J.; REICHERT, J.M; SOARES, J.M. Fatores controladores da compressibilidade de um Argissolo Vermelho-Amarelo Distrófico Arênico e de um Latossolo Vermelho Distrófico Típico. I - Estado inicial de compactação. Revista Brasileira de Ciência do Solo, v.26, n.1, p.1-8, 2002a.

SILVA, V.R.; REINERT, D.J.; REICHERT, J.M; SOARES, J.M. Fatores controladores da compressibilidade de um Argissolo Vermelho-Amarelo Distrófico Arênico e de um Latossolo Vermelho Distrófico Típico. II - Grau de saturação em água. Revista Brasileira de Ciência do Solo, v.26, n.1, p.9-16, 2002 b.

SINGER, M.; EWING, S. Soil quality. In: SUMNER, M.E. (Ed.) Handbook of soil science. Boca Raton: CRC Press, 2000. p.271-298. 
SKIDMORE, E.L.; LAYTON, J.B. Dry-soil aggregate as influenced by selected soil properties. Soil Science Society of America Journal , v.56, n.2, p.557-561, 1992.

SMITH, C.W.; JOHNSTON, M.A.; LORENTS, S. Assessing the compaction susceptibility of South African forestry soils. I. The effect of soil type, water content and applied pressure on uni-axial compaction. Soil and Tillage Research, v.41, n.1/2, p.53-73, 1997a.

SMITH, C.W.; JOHNSTON, M.A.; LORENTS, S. Assessing the compaction susceptibility of South African forestry soils. II. Soil properties affecting compactibility and compressibility. Soil and Tillage Research, v.43, n.3/4, p.335354, $1997 b$.

SNYDER, V.A.; VÁZQUEZ, M.A.; MARTÍNEZ, G.; RAMÍREZ, L.; HADAS, A. Controlled displacement technique for measuring soil friability. Soil Science Society of America Journal, v.59, n.1, p.44-52, 1995.

SOANE, B.D. Process of soil compaction under vehicular traffic and means of alleviating it. In: LAL, R.; SANCHEZ, P.A.; CUMMINGS, R.W. (Ed.) Land clearing and development in the tropics. Rotterdam: Balkema Publ., 1986. p.265-297.

SOANE, B.D. The role of organic matter in soil compactability: a review of some practical aspects. Soil and Tillage Research, v.16, n.1/2, p.179-201, 1990.

SOANE, B.D.; BLACKWELL, P.S.; DICKSON, J.W.; PAINTER, D.J. Compaction by agricultural vehicles - a review. 1. Soil and wheel characteristics. Soil and Tillage Research, v.1, n.4, p.207-237, 1981a.

SOANE, B.D.; BLACKWELL, P.S.; DICKSON, J.W.; PAINTER, D.J. Compaction by agricultural vehicles - a review. 2. Compaction under tyres and other running gear. Soil and Tillage Research, v.1, n.4, p.373-400, 1981 b.

SOANE, B.D.; VAN OUWERKERK, C. Soil compaction problems in world agriculture. In: SOANE, B.D.; VAN OUWERKERK, C. (Ed) Soil compaction in crop production. Amsterdam: Elsevier, 1994. p.1-21.

SOIL SCIENCE SOCIETY OF AMERICA. Glossary of soil science terms. http://www.soils.org/sssagloss/, (21 Maio 2002). 
STATISTICAL ANALYSIS SYSTEM INSTITUTE. SAS/STAT procedure guide for personal computers. 5.ed. Cary: SAS Institute, 1991. 1104p.

STENBERG, B. Monitoring soil quality of arable land: microbiological indicators. Soil and Plant Science, v.49, n.1, p.1-24, 1999.

TAYLOR, D.W. Fundamentals of soil mechanics. New York: John Wiley, 1948. $770 \mathrm{p}$.

TAYLOR, H.M.; ROBERSON, G.M.; PARKER, J.J.JR. Soil strength-root penetration relations to medium to coarse-textured soil materials. Soil Science, v.102, n.1, p.18-22, 1966.

TERZAGHI, K.; PECK, B.R. Soil mechanics in engineering practice. New York: Wiley. 1967. 566p.

TIJINK, F.G.J.; LINDEN van der, J.P. Engineering approaches to prevent subsoil compaction in cropping systems with sugar beet. In: HORN, R.; AKKER van den, J.J.H.; ARVIDSSON, J. (Ed.) Subsoil compaction: distribution, processes and consequences. Reiskirchen: Catena Verlag, 2000. p.442-452. (Advances in GeoEcology, 32)

TOPP, G.C.; REYNOLDS, W.D.; COOK, F.J.; KIRBY, J.M.; CARTER, M.R. Physical attributes of soil quality. In: GREGORICH, E.G.; CARTER, M.R. (Ed.) Soil quality for crop production and ecosystem health. Amsterdam: Elsevier Science, 1997. p.21-58.

TORMENA, C.A.; SILVA, A.P. da; LIBARDI, P.L. Caracterização do intervalo hídrico ótimo de um Latossolo Roxo sob plantio direto. Revista Brasileira de Ciência do Solo, v.22, n.4, p.573-581, 1998.

TOWNER, G.D. The influence of sand- and silt-size particles on the cracking during drying of small clay-dominated aggregates. Journal of Soil Science, v.39, n.3, p.347-356. 1988

UTOMO, W.H.; DEXTER, A.R. Soil friability. Journal of Soil Science, v.32, n.3, p.203-213, 1981. 
VEENHOF, D.W.; MCBRIDE, R.A. Overconsolidation in agricultural soils: I. Compression and consolidation behavior of remolded and structured soils. Soil Science Society of America Journal, v.60, n.2, p.362-373, 1996.

VERMEULEN, G.D.; PERDOK, U.D. Benefits of low ground pressure tyre equipment. In: SOANE, B.D.; VAN OUWERKERK, C. (Ed.) Soil compaction in crop production. Amsterdam: Elsevier, 1994. p.447-478.

VOORHEES, W.B.; FARREL, D.A.; LARSON, W.R. Soil strength and aeration effects on root elongation. Soil Science Society of America Proceedings, v.39, n.5, p.948-953, 1975.

WATTS, C.; DEXTER, A.R. The influence of organic matter in reducing the destabilization of soil by simulated tillage. Soil and Tillage Research, v.42, n.2, p.253-275, 1997.

WATTS, C., DEXTER, A.R. Soil friability: theory, measurement and the effects of management and organic carbon content. European Journal of Soil Science, v.49, n.1, p.73-84, 1998.

WEAICH, K.; CASS, A.; BRISTOW, K.L. Use of a penetration resistance characteristic to predict soil strenght development during drying. Soil and Tillage Research, v.25, n.1-2, p.149-166, 1992.

WÖSTEN, J.H.M.; PACHEPSKY, YA.A.; RAWLS, W.J. Pedotransfer functions: bringing the gap between available basic soil data and missing soil hydraulic characteristics. Journal of Hydrology, v.251, p.123-150, 2001.

ZHANG, H.; HARTGE, K.H.; RINGE, H. Effectiveness of organic matter incorporation in reducing soil compactability. Soil Science Society of America Journal, v.61, n.1, p.239-245, 1997.

ZOU, C.; SANDS, R.; BUCHAN, G.; HUDSON, I. Least limiting water range: a potential indicator of physical quality of forest soils. Australian Journal of Soil Research, v.38, n.5, p.947-958, 2000. 